\title{
A Monograph of the Geoglosseae.
}

\author{
BY \\ GEORGE MASSEE, F.L.S. \\ Principal Assistant (Cryptogams), Royal Herbarium, Kew. \\ With Plates XII and XIII. \\ $\rightarrow+$
}

\section{MORPHOLOGY AND REPRODUCTION.}

T $\mathrm{HE}$ amount of histological differentiation is very slight throughout the entire group: parenchymatous tissue, resulting from the complete union on every surface of hexagonal, more or less isodiametric cells, so characteristic of the 'cortex' or external stratum of the ascophore in other groups of the Discomycetes, is entirely absent from the members of the Geoglosseae; and in some of the most primitive species, as Geoglossum hirsutum, there is no clear line of demarcation between the fertile or ascigerous portion of the ascophore and the sterile or stem-like base. The stem in all known species is elongated and somewhat slender, and consists of a bundle of slender, transversely septate, usually unbranched hyphae, which are parallel and densely packed together at the periphery, and become lax and more or less interwoven at the centre. If a transverse section of a young stem is examined under the microscope it will be seen that the component cells separate readily from each other if the cover-glass is moved laterally, whereas in a 


\section{Massee.-A Monograph of the Geoglosseae.}

mature stem the peripheral cells are bound together by a ground-work of mucilage derived from the gelatinization of the outer layer of the cell-walls. The axial cells of the stem, and also of the ascigerous portion, usually become completely resolved into mucilage, which remains in the cavity thus produced. In dry weather the plant is fairly rigid, owing to the persistent hyphae of the 'cortical' or peripheral portion being cemented together by the indurated mucilage, whereas in rainy weather the entire fungus is lax and slimy, the dissolved mucilage dripping away in some species. The velvety or squamulose surface of the stem present in some species is due to the outgrowth of the free ends of the ascending peripheral hyphae (Fig. 86).

The hyphae of the stem pass without any modification to form the terminal club-shaped or pileate ascigerous portion, which is more or less hollow or spongy towards the centre, the hyphae branching and forming a densely interwoven peripheral layer or hypothecium, the numerous free ends of which either grow out into asci containing the spores, or continue as vegetative hyphae known as paraphyses. The component cells of the hypothecium show protoplasmic continuity very distinctly (Fig. 53). The asci and paraphyses, closely packed side by side, form the superficial layer or hymenium, which covers the entire surface of the fertile portion of the ascophore. In Geoglossum hirsutum and its several varieties, there are present in the hymenium, in addition to the asci and paraphyses, numerous black, pointed, rigid hyphae which resemble porcupine-quills when seen under the microscope; these spines project beyond the general level of the asci, and are also present on the stem, giving the entire fungus a minutely velvety appearance. When quite young these spines are hyaline and sparsely transversely septate; as growth proceeds the cell-wall becomes black, opaque, and rigid (Figs. 10 and $3 \mathrm{I} a$ ).

These spines are morphologically identical and homologous with the bodies called metuloids by Cooke ${ }^{1}$, that are met 
with in the hymenium of the lowest types of the Basidiomycetes, as Hymenochaete, where, as in Geoglossum, the spines are rigid and coloured, and project above the general level of the hymenium, giving it a velvety appearance, and possibly exercising a protective function in preventing the surface of the hymenium from being eaten by minute snails, \&c., as is the case with the unprotected hymenium of the allied genera Corticium and Stereum. In Peniophora, a genus closely allied to Hymenochaete, the spines are colourless, not so rigid, and the surface of the exposed portion when old is usually incrusted with particles of oxalate of lime. From this type of structure of the spines we pass on by a gradual transition to what are known as cystidia; large, sterile cells of various shapes, present in the hymenium of many species of the Agaricineae. The primitive spine-like form of structure present in Geoglossum also occurs in the simplest known types of other groups of Fungi, as the Hydneae, Clavarieae, \&c.

The asci are elongated and narrowly clavate, the apex somewhat narrowed, thick-walled, and furnished with an apical plug of a substance which becomes coloured clear blue when treated with a solution of iodine (Fig. II). According to Boudier's ${ }^{1}$ system of classification, the fleshy Discomycetes are divided into two primary groups depending on the mode of dehiscence of the asci. The Geoglosseae belong to the Inoperculés, characterized by the asci opening at the apex by a small circular opening having a raised, torn margin, or by an elongated slit; the rupture being effected by the swelling of the apical plug that becomes blue with iodine (Fig. 64). In the second group, called the Operculés, dehiscence takes place in a circumscissile manner, the apex of the ascus separating along a clearly defined line, like a lid, which either falls completely away, or remains attached by one side, looking like an upraised, hinged lid after dehiscence. The Ascoboleae are typical examples of the Operculés.

There are normally eight spores in an ascus; in the lowest

${ }^{1}$ Bull. Soc. Mycol. France, I, 97, 1885 . 


\section{Massee.-A Monograph of the Geoglosseae.}

types these are, as is usual throughout the Fungi, large and coloured, also multiseptate and arranged in a parallel fascicle in the ascus-this is the condition of things in Geoglossum; in Spathularia the spores are of the same type of structure, but hyaline or colourless. In Mitrula the spores are much smaller, hyaline, having few, or in some species no septa, and are arranged in two rows in the ascus. Finally, in the monotypic genus Neolecta, from Brazil, the spores are minute, globose, hyaline, and arranged in a single row in the ascus. In many species the spores are ejected elastically at maturity, but are often prevented from being diffused at once by the slime present on the hymenium. In the aquatic species, Vibrissea iruncorum, the spores protrude from the ascus when mature, and are dispersed by the water.

No species belonging to the Geoglosseae has, so far as is at present known, a conidial form of reproduction.

All the species are saprophytes, growing on the ground or on dead leaves, \&c., in damp places, and some few species are aquatic.

Bearing on the vexed question of sexual reproduction in the Discomycetes, the researches of Tulasne ${ }^{1}$ on Ascobolus furfuraceus and Peziza melaloma, Woronin ${ }^{2}$ on the structure and development of Ascobolus pulcherrimus, and De Bary ${ }^{3}$ on Peziza (Pyronema) confuens, are well known, as is also the refutation of these respective statements by Brefeld ${ }^{4}$, who denies the presence of sexual organs of functional value in the entire group. Van Tieghem ${ }^{5}$ has also brought some strong evidence to bear against De Bary's sexual theory. Finally, Dangeard ${ }^{6}$ has quite recently discovered what he considers to be an undoubted method of sexual reproduction, present not only in the Ascomycetes, but in the Fungi generally. The constant characteristics of this mode of sexual repro-

1 Ann. Sci. Nat., Sér. V, Tom. VI (1866).

${ }^{2}$ Beitr. z. Morphol. und Physiol., Pilze, Heft II.

${ }^{3}$ Morphol. und Physiol., Pilze, I62-164.

${ }^{4}$ Bot. Unters. uiber Schimmelpilze.

5 Traité général de Botanique, ed. II, pp. Ir 32 and I 166.

${ }^{6}$ Le Botaniste, IV, 2 I (I 894 ). 
duction are said to be as follows:-(1) the existence of distinct gametes; (2) the fusion of nuclei; (3) the determinate number of bipartitions of the sexual nucleus.

This mode of sexual reproduction, so far as the Ascomycetes are concerned, was first clearly observed by Dangeard in Peziza vesiculosa, Bull., and may be briefly summarized as follows :-

The stroma or hypothecium gives origin to the asci and paraphyses; the latter are simply unmodified filaments of mycelium, and require no special notice; on the other hand, each ascus owes its existence to the presence of an oospore, which originates as follows :-

Two filaments approach each other until they are in contact at the tips, the apical cell of each contains a single nucleus; these are the two gametes, male and female respectively; the apical cells of these gametes anastomose or conjugate, their protoplasm mixes, and the two large nucleolate nuclei fuse almost immediately, forming the oospore, which occupies the extremity of two conjugating filaments. Finally the apex of the oospore elongates and grows into an ascus, into which the nucleus ascends, and by repeated bipartition produces a nucleus for each spore contained in the ascus (Fig. 92).

Immediately following the above statement, Dangeard adds, as a rider, that in addition to the production of the oospore by the conjugation of two distinct gametes, he has observed that in Peziza vesiculosa the oospore is sometimes formed by the fusion of the contents of two adjacent cells of the same hypha; this admission, although speaking volumes for the unbiassed disposition of the author, rather clashes with one of the three fundamental constants of his theory of sexual reproduction, viz. the existence of distinct gametes.

I have examined Peziza vesiculosa, and also other species belonging to the Discomycetes, and have been able to confirm Dangeard's statements relating to the origin of the asci, both from the conjugation of two independent hyphae, and also from a single hypha, but at the same time I regret to say 


\section{Massee.-A Monograph of the Geoglosseae.}

that I cannot accept his interpretation of the process for the following reasons:-

During a microscopic examination of the species of Peniophora and Hymenochaete undertaken some years ago, I was very much struck by repeatedly observing the metuloids or spine-like hymenial appendages to be furnished with a bifurcate base. Failing to offer a satisfactory explanation of this curious structure, the matter passed from my mind until the appearance of Dangeard's figures illustrating the conjugation of his gametes. Returning to the subject, I found that in Peniophora velutina the spines certainly did originate from the fusion of two distinct hyphae, but the conjugation occurs deep down in the interwoven substance of the subiculum, and is altogether too minute to show with certainty the fusion of the nuclei to form Dangeard's so-called oospore. It may here be stated that Cooke has, years ago, described and figured ${ }^{1}$ the metuloids of Peniophora with a bifurcate base. I have also ascertained that the spines in the hymenium of Hymenochaete, Veluticeps, and Geoglossum hirsutum originate from the fusion of two hyphae. Considering, as already stated, that the gigantic cells known as cystidia, present in the hymenium of numerous species belonging to the Agaricineae, are homologous with the metuloids of Peniophora and Geoglossum, these were examined, and in Coprimus atramentarius showed very clearly the whole of the process as described by Dangeard, the approach of two independent hyphae until their apical cells were in contact, the fusion of these two cells, also of the two nuclei, finally the growth of the gigantic cell or cystidium from the oogonium, and the wandering of the nucleus into the cystidium (Fig. 9I).

This peculiar structure of the cystidia being supported on two 'gametes' has also been previously recorded and figured by W. G. Smith ${ }^{2}$, who writes as follows:-' In conclusion, I will advert to the way in which the cystidia in Gomphidius are borne. In many instances, if not in all, they arise from

1 Grevillea, VIII, 21, Pl. I25, f. 16, I879.

${ }^{2}$ Ibid. X, 79, Fig. J., I88I. 
two conjoined cells as at J. I have not seen basidia so arise, and it looks superficially like what is termed conjugation.'

It may be argued that cystidia and metuloids, being hymenial appendages, are degraded basidia or asci, and thus their origin from conjugating filaments does not throw doubt as to the sexual nature of the process. To meet such a possibility, evidence of conjugation, illustrating all the details of the process as described by Dangeard, can be observed on a grand scale in the formation of the large hairs covering the exterior of the ascophore in species of Ascobolus, Lachnea, Humaria, \&c. Now, in selecting protective hairs as evidence of the broadly distributed mode of formation of organs by conjugation, I think such cannot, by any amount of ingenuity, be considered as aborted spore-producing structures, but as purely vegetative parts of the ascophore. Figs. 93, 94, and 95 illustrate the mode of origin of the hairs from the ascophore of Lachnea albo-spadicea, Phillips; using the terms employed by Dangeard, the parts of the figures indicated would stand as follows: $-a$, gametes; $b$, oospore (not complete in Fig. 93, as the two nuclei have not yet fused); $c$, the hair, which is a direct outgrowth of the oospore. Probably any species of Lachnea or pilose Ascobolus would give the same results, as the gigantic spinulose, thick-walled hairs borne by these species have the base furcate. The reader is referred to the numerous figures of hairs from the Discomycetes given in Cook's Mycographia, showing the furcate base. Finally, the fungus called Ciliaria bicuspis, by Boudier ${ }^{1}$, is so named on account of the bicuspid or forked base of the large hairs present on the margin and outside of the ascophore.

The above observations show that the coalescence of the apical cells of two distinct hyphae does not prove, in all cases, that these hyphae are gametes, in the usual sense in which that term is employed. Secondly, that the coalescence of two cells, the mixing of their protoplasm, and the fusion of their nuclei, does not necessarily constitute an oospore;

\footnotetext{
1 Bull. Soc. Myc. France, XII, I I, Pl. III, f. I, 1896.
} 


\section{Massee.-A Monograph of the Geoglosseae.}

and that under certain conditions, where these two conditions are fulfilled, a purely vegetative structure is produced as the result of such conjugation; consequently there is no evidence to prove that the conditions described by Dangeard as constituting a sexual act in the formation of the asci in the Ascomycetes are such in reality.

In some of the largest hairs present on the species of Lachnea it is not unusual for three 'gametes' to fuse at the tips to form the 'oospore,' and during the increase in size of the hair growth is often very unequal in the swollen basal portion, or 'oospore,' which frequently results in the supports or 'gametes' being separated from each other, and carried, apparently for some distance, up the hair, which then presents the appearance of a stem with three root-branches starting at slightly different levels. Owing to local growth at the basal portion of the hair, even when only the usual two 'gametes' are present, these not unfrequently eventually stand at different levels, and as the hair increases in size and becomes thick-walled, the 'gametes' also become indurated and coloured.

The most successful preparations for demonstrating the points of structure described above were obtained by first placing portions of the gills of a very young Coprinus, or the entire young plants of Lachnea, for four hours in a saturated solution of corrosive sublimate, to which a trace of acetic acid is added. After quickly washing in tap-water, the material is placed in absolute alcohol, where it can remain for an indefinite time. Sections are first placed in a very slight aqueous solution of nigrosin containing 4 per cent. of acetic acid, and afterwards transferred to a stronger solution of nigrosin alone; here they may remain for twenty-four hours, when they should be examined, and again replaced, if the nuclei are not sharply differentiated. The material would probably be best put up in balsam; mine were spoiled as permanent preparations by mounting in equal proportions of glycerine and water, with a trace of carbolic acid.

The above observations seem to suggest the idea that when 
specially large organs, such as asci, cystidia, or hairs, have to be produced, a usual method of effecting this is by the amalgamation of the apical cells of two independent hyphae.

The recent researches of Harper ${ }^{1}$ on the sexual mode of reproduction in Sphaerotheca Castagnei tend to show that the observations of De Bary bearing on the question of sexuality in the Ascomycetes were in the main correct; nevertheless Harper's more detailed account rather upsets the generally accepted idea that the Ascomycetes are derived from the Phycomycetes, he having shown that in Sphaerotheca-the genus which more especially led De Bary to entertain this view-after fertilization of the carpogenic cell, a series of superposed cells is formed, and from one of these, and that not the terminal one, the ascus is formed; hence the ascus in Sphaerotheca is not directly homologous with the oogonium of the Phycomycetes.

It is the tendency at present to endeavour to trace groups presenting a general morphological resemblance to a common origin; nevertheless, the large group of organisms described by Thaxter ${ }^{2}$ under the name of Laboulbeniaceae are morphologically characteristic Ascomycetes; yet the universal sexual mode of reproduction in this group by non-motile antheridia and trichogynes is essentially Floridean in character, and difficult to reconcile with the sexual process as described by Harper in Sphaerotheca, also a typical Ascomycete, and seems to necessitate the admission that what we at present term Ascomycetes will prove to be a heterogeneous assemblage, and that the single bond of agreement-the production of ascospores-does not necessarily indicate a unity of origin of the members possessing this feature.

${ }^{1}$ Die Entwickelung des Peritheciums bei Sphaerotheca Castagnei, Ber. d. Deutsch. Bot. Gesellsch. Bd. XIII, Heft Io, 475, 1895 .

Ueber das Verhalten der Kerne bei der Fruchtentwickelung einiger Ascomyceten, Prings. Jahrb. 1896,655 , Taf. XI-XII.

${ }^{2}$ Contribution towards a Monograph of the Laboulbeniaceae, Mem. Amer. Acad., XII, No. III, I896. 


\section{Massee.-A Monograph of the Geoglosseae.}

\section{Affinities.}

The constant characteristics of primitive types of Fungi in the various families of both Ascomycetes and Basidiomycetes are (I) comparative absence of differentiation of the sporophore, and (2) large coloured spores, the latter being often also multiseptate and the epispore more or less ornamented. The genus Geoglossum possesses these features in a very pronounced form; the ascophore is a simple, erect, more or less clubshaped structure, the upper portion of which is fertile, the thinner basal portion sterile, and called the stem. In G. hirsutum, the simplest form known, the transition from the sterile to the fertile portion is not indicated externally; in the other species there is a very slight ridge at the commencement of the ascigerous portion. The spores in all the species are large, brown, and multicellular; but there is a gradual decrease in the size of the spores and in the number of component cells from $G$. hirsutum, where the spores are almost as long as the ascus, and consist of fourteen cells, to the G. glutinosum group, in which the spores are shorter, and generally four-celled. In all the species of Geoglossum every part of the plant is black externally.

Following directly we have the genus Mitrula, the black species of which are externally quite indistinguishable from the species of Geoglossum, but are supposed to be generically distinct on account of the somewhat shorter, hyaline spores, which in the simplest forms are often four-celled, and in the highest forms have become very small and one-celled. In Mitrula the terminal ascigerous portion becomes more sharply defined from the stem, and is also often brightly coloured, every portion being covered by the hymenium. The next genus in the sequence of evolution is Leotia, which agrees with Mitrula so far as the spores are concerned, but differs in the form of the ascigerous portion, which is more or less pileate, or shaped like the cap of an Agaric, the margin curving inwards towards the stem. If we imagine the hollow, erect, fertile portion in Mitrula (Figs. 54, 59, 60) pressed down 
from the apex, we get the pileate form of Leotia; and in some of the higher forms of Mitrula this condition sometimes occurs, thus illustrating the so-called transition phases between those groups of species possessing several features in common, which we call genera.

The spores in Spathularia are of the Geoglossum type, but colourless; whilst the ascigerous portion is more sharply differentiated from the stem than in Geoglossum, and is also frequently laterally compressed or spathula-shaped, more especially in the species on which the genus is founded, whence the generic name. Finally, Vibrissea has the Spathularia type and colour of spore, but the ascigerous portion is pileate, thus differing from Spathularia in the same manner that Leotia differs from Mitrula.

From the above remarks it may possibly be inferred that genera in the Fungi are somewhat shadowy, but in reality not more so than in other branches of the Vegetable Kingdom, and perhaps our knowledge of true affinities becomes more exact in proportion as our belief in genera as entities becomes less.

The transition from the Geoglosseae to other families of the Discomycetes is gradual; the line between species of Leotia and Ombrophila belonging to the Bulgarieae is purely a matter of personal opinion; the same may be said of the species of Vibrissea and Gorgoniceps, the latter belonging to the Pezizeae. Leotia shades into Verpa belonging to the Helvelleae on the one hand, and on the other into Helotium, belonging to the Pezizeae. Finally, Helvella of the Helvelleae leads very gradually into Geopyxis, belonging to the Pezizeae.

The diagram on p. 236 shows the evolution of the genera of the Geoglosseae from Geoglossum; also the origin of the Helvelleae, Bulgarieae, and Pezizeae from the Geoglosseae.

\section{Distribution.}

In dealing with problems relating to distribution, mere numbers are apt to mislead, owing to our comparatively 


\section{Massee.-A Monograph of the Geoglosseae.}

unequal knowledge respecting the floras of different countries, and this imperfection is especially pronounced with regard to Fungi, which are, as a rule, altogether neglected by collectors, and even by botanists having no special interest in the group.

In the Geoglosseae however, fortunately, the general morphology and comparative differentiation of the species supports the numerical evidence bearing on the origin and gradual dissemination of the family. The Geoglosseae represent a primitive type of the Discomycetes, which as an order is comparatively modern compared with the remainder of the

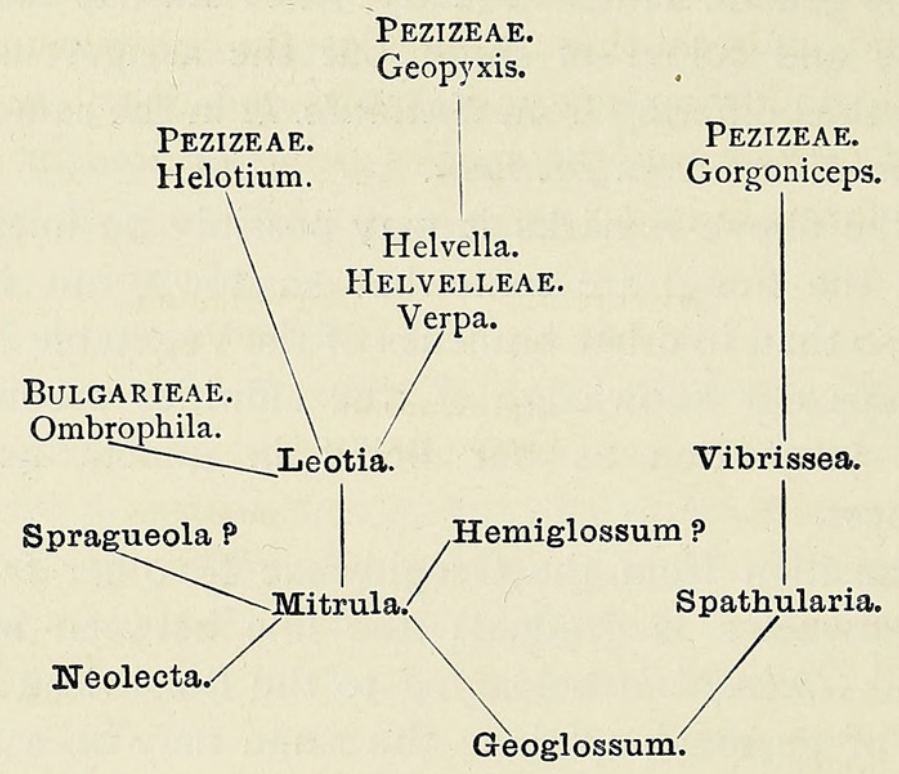

Ascomycetes, the Hysteriaceae, Sphaeriaceae, Tuberaceae, \&c.; and the entire evidence points to Northern Europe as being the cradle of this interesting family. An analysis of the distribution of Geoglossum, the most primitive genus included in the family, will serve as a model, the remaining large genera following along similar lines. The following points stand out very clearly:-(I) The primitive and oldest genera have the most closely allied species, and even these are connected by forms and varieties. (2) Varieties and forms become more abundant the further the species extend from the original home of the genus.

Geoglossum contains seven species, six of which occur in 


\section{Massee.-A Monograph of the Geoglosseae.}

Europe, the seventh-G. pumilum-being recorded only from Brazil. G. hirsutum, the most primitive species in the genus, is represented in the Kew Herbarium, in the typical form, from the following places:-Franz Josef Archipelago, Europe, Mauritius, Java, Australia, New Zealand, Bermuda, United States. This species has four forms or varieties, only two of which-Walteri and americanum-occur in Europe, where both are very rare, whereas both are not uncommon in those distant parts of the world where the type-form is rare. Of the two remaining forms-leotioides and velutipes-the former is confined to New Zealand and the latter to the United States, and in both these countries the type-form is again rare. The following diagram shows the distribution of the species of Geoglossum, the species being printed in clarendon type, the forms in italics:-

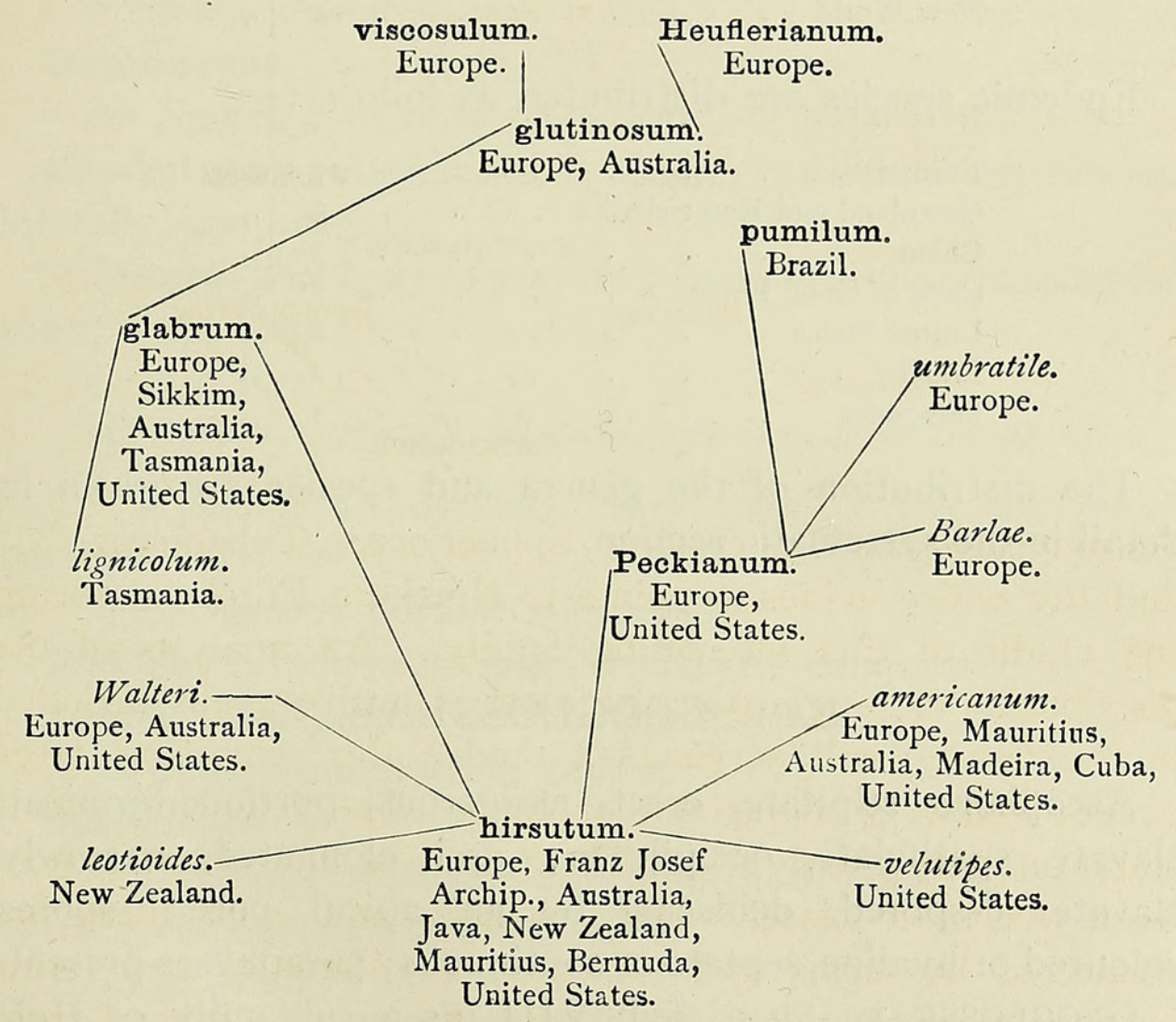

In the present work the group Geoglosseae includes eight genera; but of these, Spragueola, a genus of my own 


\section{Massee.-A Monograph of the Geoglosseae.}

founding, is far from being stable, and its one species may possibly prove to belong to the older genus Mitrula. Again, it is somewhat doubtful as to whether the genus Hemiglossum belongs to the present family; its only species suggests affinity with Midotis, but as I have had no opportunity of verifying this or otherwise, I accept the affinity indicated by its founder, Patouillard. Of the remaining six genera, with a total of fifty-eight species, five genera have their head-quarters in Europe, and include forty species. The extra-European genus Neolecta, including one species, is confined to Brazil. The distribution of species throughout the world is shown in the following table:-

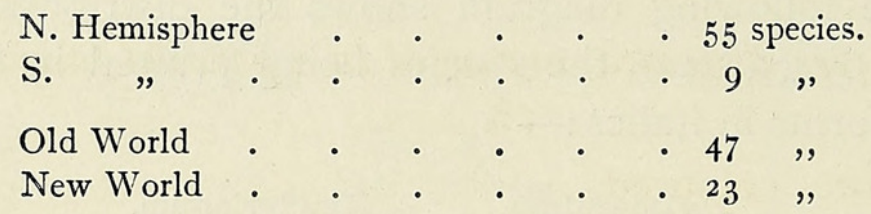

Endemic species are distributed as follows:-

\begin{tabular}{|c|c|c|c|}
\hline Europe : & $\cdot \quad \cdot \quad \cdot$ & & 7 \\
\hline Greenland and & Kamtschatka & & \\
\hline China & ..$\quad \cdot$ & 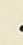 & 3 \\
\hline Cape of Good & Hope & . & I \\
\hline United States & & & 8 \\
\hline Brazil . & . & & 2 \\
\hline Patagonia & & & I \\
\hline
\end{tabular}

The distribution of the genera and species are given in detail in the systematic section.

\section{FAM. GEOGLOSSEAE.}

Ascophore stipitate, erect, ascigerous portion terminal, clavate, spathulate, or pileate; asci elongated, narrowly clavate, 8-spored, dehiscing by an apical pore; spores coloured or hyaline, septate or continuous; paraphyses present. Geoglosseae, Sacc., Syll. VIII (as a subfamily of Helvelleae).

Most closely allied to the Bulgarieae, agreeing in the more 


\section{Massee.-A Monograph of the Geoglosseae. 239}

or less gelatinous nature of the ascophore, but differing in not having a distinct plane or concave disk. The Pezizeae are also closely allied through the genus Helotium; the latter however again differs in the discoid hymenium and in the more or less parenchymatous cortex of the ascophore. Verpa, connecting the Helvelleae, differs in having the ascigerous portion more distinctly separated from the stem, and in the hymenium being sharply limited to its upper surface.

\section{KEy TO THE GENERA.}

I. Spores elongated, arranged in a parallel fascicle in the ascus.

* Spores coloured.

\section{Geoglossum.}

** Spores hyaline or colourless.

Spathularia. Ascigerous portion spathulate or clavate, laterally compressed.

Vibrissea. Ascigerous portion pileate, free margin incurved towards the stem.

II. Spores narrowly elliptical, I-2-seriate in the ascus.

* Hymenium covering every part of the ascigerous portion.

$\dagger$ Ascigerous portion stipitate.

Mitrula. Ascigerous portion clavate, compressed.

Leotia. Ascigerous portion pileate. †† Ascigerous portion sessile.

\section{Spragueola.}

** Ascigerous portion flat, hymenium covering only one surface, the other surface sterile.

\section{Hemiglossum.}

\section{Neolecta.}

\section{Spores globose.}




\section{Massee.-A Monograph of the Geoglosseae.}

\section{Geoglossum, Persoon.}

Ascophore simple, erect, clavate, entirely black, sometimes with a tinge of olive or purple; ascigerous portion terminal, either gradually passing downwards into the stem, or its lower termination more or less indicated by a slight constriction. Asci clavate, apex narrowed, pore blue with iodine; spores 8, long and slender, septate, brown, arranged in a parallel fascicle in the ascus ; paraphyses present ; black, spine-like cystidia are also present in the hymenium of some species.

Geoglossum, Pers., Obs. Mycol. i, I I, I 796 ; emended by Saccardo, Consp. Gen. Disc., Bot. Central. xviii, 2 I 4 , I884.

Trichoglossum, Boud., Bull. Soc. Myc. Fr. i, I 1о, 1885, in part.

Cibalocoryne, Hazsl., Ung. Akad. d. Wiss. xi, 8, r88 r, in part.

Clavaria, of old authors.

Most nearly allied to Mitrula, the black species of which differ in the hyaline, 2-seriate spores. Certain species of Clavaria, belonging to the Basidiomycetes, and Xylaria, belonging to the Pyrenomycetes, closely resemble the species of Geoglossum in general appearance and habit.

Distr. - The seven species included in the present genus have both individually and collectively a much wider range than those belonging to any other genus in the Geoglosseae. Six of the species-G. hirsutum, glabrum, glutinosum, Peckianum, viscosulum, and Heuflerianumoccur in Europe, the two last-named not occurring elsewhere. G. pumilum is peculiar to Brazil. The genus ranges from Franz Josef Archipelago to New Zealand, and is more frequent in warm regions than other genera; species being recorded from Cuba, Bermuda, Brazil, Java, and Sikkim. No species, so far as I am aware, have been found in China or Japan.

\section{Key TO THE SPECIES.}

\section{Spines present in the hymenium.}

\section{hirsutum.}

\section{Spines absent from the hymenium.}

glutinosum. Plant $3^{-6} \mathrm{~cm}$. high; spores almost cylindrical ; paraphyses abruptly piriform or globose at the tips. 
glabrum. Plant $3-7 \mathrm{~cm}$. high; spores narrowly clavate; paraphyses clavate at the tip, constricted at the septa.

Peckianum. Plant 4-7 cm. high; paraphyses longer than the asci, tips curled.

pumilum. Plant up to $9 \mathrm{~mm}$. long; spores 15 -septate.

viscosulum. Ascigerous portion pitted or alveolate.

Heuflerianum. Entire plant 3-4 mm. high; spores 3-septate.

Geoglossum hirsutum, Persoon, Comment. Fung. Clav. 37, I 797 ; Pers., Syn. Fung. 608, I801 ; Fries., Syst. Myc. i, 488, I82 I ; Cooke, Mycogr. 3, f. 3, 1875; Phillips, Brit. Disc. 34, pl. 2, f. 9, 1887; Sacc., Syll. viii, n. I50, I889; Massee, Brit. Fung.-Fl. iv, 492, I895; Rehm, Kr.-Fl. n. 5876, I896. (Pl. XII, Figs. 31, 3 I a, $3^{2}$.)

Gregarious or caespitose ; entire fungus $4-7 \mathrm{~cm}$. high, black, dry, everywhere densely velvety; ascigerous portion $\frac{1}{4}-\frac{1}{2}$ the length of the entire fungus, lanceolate, ovate, oblong, or almost globose, generally more or less compressed and longitudinally wrinkled, sometimes irregular in form and crooked, densely velvety, due to the projection of closely packed, pointed black hairs (cystidia), up to $I^{\cdot} 5 \mathrm{~cm}$. broad, scarcely or not at all differentiated from the equally velvety stem. Asci clavate, apex narrowed, pore blue with iodine, $160-220 \times 18-20 \mu$; spores 8 , arranged in a parallel fascicle in the ascus, linear, almost cylindrical, ends very slightly narrowed, multiguttulate, then 7 - and finally I 5 -septate, often slightly curved, I I O-I $50 \times 5^{-6} \mu$, light umber brown, translucent; paraphyses slender, septate, tips brown, clavate, curved, slightly longer than the asci; cystidia or spines numerous, straight-pointed, black and opaque, paler towards the base, narrowly fusiform, 8-10 $\mu$ thick.

Syn.-Clavaria simplex hirsuta, Schmidel, Icon. Plant. 92, tab. xxv, I 762 .

Clavaria ophioglossoides, Sawerby, Eng. Fung. tab. 83 , I 797 .

Geoglossum hirsutum $\beta$ capitatum, Pers., Syn. Fung. 608, I801.

Trichoglossum hirsutum, Boudier, Bull. Soc. Myc. i, I Io, I885.

Exs.-Holl, Schmidt, and Kunze, Deutschl. Schw., n. cxxii ; Moug. and Nest., Stirp. Crypt. n. 94 ; Crepin, Herb. Bot. Belge, n. I084; Roum., Fung. Gall. n. 4043 ; Rabenh., Fung. Eur. n. 523 ; KlotzschRabenh., Herb. Myc. n. 44 and 237 ; Sydow, Myc. March. n. 440 and ro69; Fuckel, Fung. Rhen. n. II4I; Allescher and Schnabl, Fung. Bavar. $35^{2}$; Cooke, Fung. Brit. n. 393 ; Desm., Crypt. France, sér. I, 


\section{Massee.-A Monograph of the Geoglosseae.}

n. 420 ; Karsten, Fung. Fenn. n. 45I ; Roumeg., Fung. Gall. Select.

n. 63 ; Vize, Micro.-Fung. n. 481 .

Hab.-On damp ground among grass, \&c.

Distr.-Britain, Ireland ; Portugal (Henriquez); France ; Denmark ; Sweden; Germany; Holland; Belgium; Austria; Switzerland ; Italy ; Finland; Mauritius (Telfair); Bermuda (Devonshire marsh, Challenger Exp.); New Zealand (Colenso); Java; Victoria (Müller); United States (Sandlake, N.Y., Peck; New England; Massachusetts ; Louisiana, Hale, n. 366r); Franz Josef Archipelago (Cape Flora, alt. $60 \mathrm{ft}$., Jackson-Harmsworth Polar Exp., coll. Fisher).

The present species, in its typical form, is readily known by the densely velvety texture of every part of the fungus. The typical number of septa in the spore is $\mathbf{I}_{5}$, but not unfrequently there are fewer in some of the spores of a plant having as a rule the normal number, and in one instance I have seen two of the spores in an ascus with I $_{9}$ septa each, the remaining six having the usual $\mathrm{I}_{5}$ septa.

Persoon's var. capitata is not a constant variety, nor even a constant form; it was established by Persoon upon two of the figures in Schmidel's plate which occur in a long series showing the variation of form of the ascigerous portion, which passes gradually from the most usual, lanceolate, through ovate, shortly clavate, obovate, and subglobose.

\section{Form americanum.}

Spores 100-1 $25 \times 5-6 \mu$; usually 7-9-septate, pale brown; cystidia or spines scarcely longer than the asci, hence the hymenium appears to be almost glabrous when seen under a lens.

Syn.-Geoglossum hirsutum, var. americanum, Cooke, Mycogr. 3, fig. 1,1875 .

Geoglossum americanum, Sacc., Syll. viii, n. I51, I 889 .

Hab.-On the ground among grass, \&c.

Distr.-Britain (Penzance; Glasgow, Bot. Garden; Twycross, Berkeley); France (Desm., Crypt. France, sér. i, n. 420, some of the specimens); Germany (Holl, Schmidt, and Kunze, Deutschl. Schwämme, xcvii, some of the specimens; Mougeot and Nestler, Stirpes Crypt. 94, also 95, the lower specimen; Ratzeburg, Rudolphi); Hungary (Thïmen, Fung. Austr. n. 927); Madeira (Lowe); Cuba (Wright); Mauritius ; Victoria ; Queensland ; United States (N. York, Gerard, n. 53 ; Louisiana, Hale). 
Differs mainly from the typical form in the reduced length of the spines, and in the somewhat shorter spores with fewer septa, 7-9 being the most frequent numbers, although it is not unusual to find odd spores with a greater number of septa; I have seen a spore with I 5 septa in the same ascus with seven others having 9 septa each, in Cooke's type of var. americanum.

Form Walteri. (Pl. XIII, Figs. 78-80.)

Spores $60-75 \times 5^{-6} \mu$ pale brown, most frequently $3-5$-septate, but occasionally $7-9$-septate; spines scanty, not at all, or only very little, longer than the asci.

Syn.-Geoglossum Walteri, Berk., in Cooke, Mycogr. 4, fig. 4 (which is altogether inaccurate); Sacc., Syll. viii, n. I49, I889.

Geoglossum Farlowi, Cooke, Grev. xi, 107, 1883; Sacc., Syll. viii, n. 148,1889 .

Hab.-Among grass and on trunks of tree-ferns.

Distr.-Britain (Twycross, Bloxam), United States (Newton, Mass., Farlowe), Australia (Wild Dog Creek, Apollo Bay).

This condition may be considered as a continuation of the reduction in length of spines, and size and number of septa of the spores, commenced in form americanum. In the present form the spores are most frequently 3 -septate.

Cooke first suggested $G$. Walteri as a species to Berkeley, the latter having considered it as $G$. hirsutum, whereupon Berkeley gave the specific name of Walteri, leaving Cooke to draw up a diagnosis of the species. Judging alone from the figure and description given in Mycographia $(4$, f. 4 ), the form appears to have no close affinity with G. Farlowi, Cke., but I have carefully examined the type, and find that Cooke has drawn the spines too long-they are in reality not much longer than the asci; the spores are also too long, and the 3 -septate form is most usual.

Following the diagnosis of G. Farlowi (Grev. xi, 107), Cooke says, 'It is very much a matter of opinion whether this (G. Farlowi) and $G$. Walteri, C., and $G$. velutipes, $\mathrm{Pk}$., should be regarded as varieties of G. hirsutum, or as distinct species.'

\section{Form velutipes.}

Subcaespitose, black; club [=ascigerous portion] short, compressed; stem densely clothed with a very black, velvety pubescence. Asci 


\section{Massee. - A Monograph of the Geoglosseae.}

lanceolate; spores fasciculate, at first simple or triseptate, then elongated and 9-I I-septate, brown, $.002^{\prime}-.005^{\prime}$ long [=about 50-I $20 \mu$ ]; paraphyses septate, recurved at the tips.

Syn.-Geoglossum velutipes, Peck, 28th Rep. N. Y. State Mus. 65, 1875, figured on pl. I, f. I6-19, of the 29 th Report ; Sacc., Syll. viii, n. 152,1889 .

Hab.-Ground in hemlock woods.

Distr.-United States (Oneida, Northville).

This species is easily distinguished, both by its somewhat caespitose habit and its very black, hairy stem. The difference between the young and the mature spores is quite noticeable. I have not seen specimens of G. Walteri, a hairy species from Australia; but as it is said to have the spores 7 -septate, it must be distinct from our plant.

The above is a reproduction of Peck's description of the species. The author depends too implicitly upon the number of septa present in the spore, which is indeed a most fallacious character. I have had no opportunity of examining specimens, and it is uncertain as to which of the forms it is most closely allied. The subcylindrical spores and paraphyses recurved at the tips prove it to be a condition of $G$. hirsutum. The figures are represented as bristling with black spines all over, but in the description the stem alone is described as velvety.

\section{Form leotioides. (PI. XII, Figs. 8-I 2.)}

Gregarious, black, entire fungus $1 \cdot 5-2 \cdot 5 \mathrm{~cm}$. high, every part velvety, with projecting, spine-like, black cystidia; ascigerous portion globose or broadly ovate, hollow, at length collapsing and drooping round the stem as in Leotia, up to $\mathbf{I} \mathrm{cm}$. diameter; stem erect, equal, straight, $\mathbf{I} \cdot 5^{-2} \mathrm{~cm}$. high, about $2 \mathrm{~mm}$. thick. Asci almost cylindrical, apex narrowed, pore blue with iodine, about $230 \times 20 \mu$; spores 8, arranged in a parallel fascicle, dingy umber, translucent, $\mathbf{~} 7$-septate at maturity, linear-cylindrical, or very slightly thickened above the middle, ends a very little narrowed, usually slightly curved, I $50-165 \times 5 \mu$; paraphyses slender, straight throughout, septate, tip slightly clavate, umber, almost straight, spines acute, black and opaque, numerous, longer than the asci.

Syn.-Geoglossum hirsutum, var. leotioides, Cooke, Grev. viii, 6I, I879; Sacc., Syll. viii, n. I50, I889; Cke., Hdbk. Austr. Fungi, 25 I, 1892 . 
Hab.-On the ground.

Distr.-New Zealand (Wellington, Travers).

Superficially resembling Persoon's capitate or globose form of $G$. hirsutum, but clearly distinguished by the longer spores and the almost straight paraphyses.

Geoglossum glutinosum, Pers., Obs. Myc. i, I I, I796;Cke., Mycogr. 5, f. 6, I875; Phil., Brit. Disc. 38, 1887; Sacc., Syll. viii, n. 136 , 1889; Massee, Brit. Fung.-Fl. iv, 490, figs. 8-1o on p. ז88, I 895 ; Rehm., Kr.-Fl. n. $5^{87}$ I, f. 7 , p. I I 45, r 896 . (Pl. XIII, Figs. 66, 67.)

Gregarious, entire fungus $3^{-6} \mathrm{~cm}$. high, black, sometimes with a tinge of olive or brown, more or less viscid; ascigerous portion lanceolate, glabrous, terete or compressed, 5-8 $\mathrm{mm}$. broad, usually about $\frac{1}{3}$ the length of the entire fungus; stem cylindrical, rather slender, viscid, often brownish black. Asci subcylindrical, apex narrowed, pore blue with iodine, 2 I0-240 $\times$ I2-I $4 \mu$; spores 8 , arranged in an imperfectly parallel fascicle in the ascus, or inclined to become irregularly 2-3-seriate, linear, almost cylindrical, ends obtuse, pale brown, translucent, generally straight, for a long time 3 -septate, sometimes passing to 5 -7-septate; paraphyses slender, septate ; tips brown, varying from abruptly piriform to globose, $7-9 \mu$ diameter.

Syn.-Geoglossum viscosum, Pers., Comm. Fung. Clav. 38, I797; Cooke, Mycogr. 8, f. 10, 1875 ; Phil., Brit. Disc. 37, 1887; Sacc., Syll. viii, n. I37, I889; Massee, Brit. Fung.-Fl. iv, 490, I895; Rehm, Kr.-Fl., n. 5870 , I 896 .

Geoglossum glutinosum, forma minor, Sacc., Mich. i, 444, 1877; Sacc., Syll. viii, under n. I36, I889 (ascophore hardly I cm. long).

Geoglossum Mülleri, Cooke, Mycogr. 4, f. 2, I 875 (spores and paraphyses incorrectly represented); Sacc., Syll. viii, n. I38, r889.

Exs. - Karsten, Fung. Fenn. n. 450; Roumeg., Fung. Gall. n. 4044 ; Mougeot and Nestler, Stirp. Crypt. n. 780 ; Desm., Crypt. France, sér. I, n. 422 ; Klotzsch-Rabenh., Herb. Myc., ed. ii, n. 3 I 9.

$H a b$.- On the ground among grass, moss, \&c.

Distr.-Britain, Portugal (Henriquez), France, Sweden, Belgium, Switzerland, Germany, Austria, Italy, Finland, Australia (Port Philip, French; Melbourne, Müller, Reader).

The chief characteristics of the present species, as defined above, 


\section{Massee.-A Monograph of the Geoglosseae.}

are: the glabrous, more or less viscid ascophore; narrow, almost cylindrical asci, and nearly cylindrical, comparatively short spores with obtuse ends, which usually remain 3 -septate. The spores are often much paler in colour than in the other species; and, owing to their shorter length, do not form such a distinct parallel fascicle in the ascus, but are inclined to become $2-3$-seriate. In going over a large series of specimens, I find it impossible to separate glutinosum from viscosum. The relative amount of viscidity depends on the weather; the terete or grooved stem depends on age, the last condition depending on the deliquescence and gelatinization of the central portion of the ascophore, which again depends on external conditions. The two extreme forms of the tips of the paraphyses, as figured by Cooke, look distinct and of value as aids to specific identification, but every possible transition from broadly piriform to globose can be met with. The spores usually remain 3 -septate, but sometimes pass on to 5-7-septate. In one specimen in Karsten's Fung. Fenn. n. 450, the spores are entirely normal in size and shape, deep brown, and apparently quite mature, but show no traces of septation. On the other hand, the specimens in Roumeguere's Fung. Gall. Exs. n. 4044, while the majority of the spores are 3 -septate, some have 5 septa and others are quite distinctly 7 -septate, the spores in the last-named instances not being above the normal size.

The form minor of Saccardo appears only to differ in its small size, and every mycologist who has done field work knows how general it is to meet with specimens belonging to almost every species of fungus that might be dubbed forma minor or major, as the case might be; but every one knows that such forms are by no means permanent, but akin to the stunted crop of wheat grown during a very dry season. Finally, I have examined the type of G. Muilleri, Cooke, and find that it agrees with G. glutinosum in all essential features; the sizes of the spores, as given by Cooke in Mycographia, are too large, and the paraphyses are in reality capitate.

Geoglossum glabrum, Persoon, Obs. Myc. ii, 61, I 799 ; Pers., Syn. Meth. Fung. 608, I801 ; Fries, Syst. Myc. i, 488, I82 I ; Cooke, Myc. 7 , f. 1о, 1875 ; Phil., Brit. Disc. 36,1887 ; Massee, Brit. Fung.Fl. iv, 49I, I 895. (Pl. XII, Figs. 44-46.)

Gregarious; entire fungus $3-7 \mathrm{~cm}$. high, dry, black or brownishblack, sometimes tinged with olive or purple; ascigerous portion $\frac{1}{3}-\frac{1}{2}$ 
the entire length of the fungus, not sharply differentiated from the stem below, glabrous, cylindric-clavate or variously deformed, 3-8 $\mathrm{mm}$. broad, sometimes laterally compressed; stem rather slender, minutely squamulose, often wavy. Asci cylindric-clavate, apex narrowed, pore blue with iodine, $165^{-2} \mathrm{I} 0 \times 18-20 \mu$; spores 8 , arranged in a parallel fascicle in the ascus, elongate-clavate, straight or very slightly curved, clear brown at first, then dark smoky brown, $75-85 \times 8-9 \mu$, 7 -septate, very slightly constricted at the septa; paraphyses septate, becoming gradually clavate upwards for the upper half, septa often rather close together near the apex, and constricted at the septa, giving a moniliform appearance, brown, $7-9 \mu$ thick at the apex, which may be straight or slightly curved.

Syn.-Clavaria ophioglossoides, Linn., Sp. Pl., ed. i, v, 2, p. II82, I 753 (fide Saccardo).

Geoglossum ophioglossoides, Sacc., Syll. viii, n. 141, 1889; Rehm, Krypt.-Flora, n. $5^{8} 72,1896$.

Geoglossum sphagnophilum, Ehrh., Sylv. Myc. 30, 1818; Sacc., Syll. viii, n. I 42, I889.

Geoglossum ophioglossoides, var. sphagnophilum, Rehm, Krypt.-Flora, n. $5^{8} 72,1896$.

Geoglossum australe, Cooke, Mycogr. 6, f. 8, I875; Sacc., Syll. viii, n. I 44,1889 .

Geoglossum simile, Peck, 25 th Report N. Y. State Mus. 97,1872 (in the 29 th Rep., Peck himself says this species is identical with G. glabrum).

Exs.-Holl, Schmidt, and Kunze, Deutschl. Schw. n. xcviii; Ellis and Everh., N. Amer. Fung. sér. 2, n. 203 I; Jack, Leiner, u. Sitzenberger, Krypt. Badens. n. 55; Moug. and Nest., Stirpes Crypt. 684, also the upper specimen in n. 95 of the same authors (the lower specimen is G. glabrum, form americanum, Cooke); Phil., Elv. Brit. Fasc. ii, n. 55 ; Rehm, Ascom. n. $5 \circ 3 a$ and $b$; Roum., Fung. Select. Gall. n. 262 ; Klotzsch-Rabenh., Herb. Myc. n. 238 ; Karsten, Fung. Fenn. n. $45^{2}$; Fuckel, Fung. Rhen. n. II 42 ; Sydow, Myc. March. n. 285 ; Rabenh.-Winter, Fung. Eur. n. 2845 .

Hab.-On the ground among grass, \&c.

Distr.-Britain, Ireland, Portugal, Spain, France, Belgium, Switzerland, Germany, Denmark, Sweden, Finland, Russia, Sikkim (Dr. [now Sir] J. D. Hooker), Tasmania (Archer), Victoria, Queensland, United States. 


\section{Massee.-A Monograph of the Geoglosseae.}

The specific characteristics of the present species are: the dry, black ascophore, distinctly clavate spores, very slightly constricted at the septa, and the paraphyses becoming clavate upwards, where the septa are rather close together and constricted, giving a moniliform appearance ; in some specimens, however, the septa are rather distant from each other near the apex of the paraphyses, which are not so strongly moniliform, whereas in others this appearance is altogether lost, and every transition may often be seen, even in the same specimen, from one extreme of paraphysis type to the other. The most constant feature of the species is the distinctly clavate form of the spores.

The above specific diagnosis is drawn up from a specimen in the Kew Herbarium called Geoglossum glabrum by Persoon himself; hence we are certain that we are so far correct. The specimens in all the exsiccati quoted have been examined, and agree with Persoon's fungus. I cannot accept Saccardo's decision that Persoon's fungus is synonymous with Clavaria ophioglossoides, Linn. The diagnosis of this species by Linnaeus (Sp. Pl., ed. i, vol. ii, p. I182, I753) is as follows: 'Clavata integerrima compressa obtusa,' and this I consider as inadequate. I have gone through the Herbarium of Linnaeus, and find nothing to support Saccardo's idea. The fact that Bulliard, Bolton, and others have called a species ophioglossoides proves nothing; in many cases, in the absence of specimens, we do not know what species, as at present understood, these authors had in view. On the other hand, where the name ophioglossoides (Linn.) is used in exsiccati, we find that it covers several species, including the hyaline spored Mitrula microspora of the present work, as in Desm., Crypt. France, sér. I, n. 42 I. Finally, Schmidel (Icon. Plant. 92, I 762) considers that the fungus Linnaeus had in view was Schmidel's Clavaria simplex hirsuta ( $=G$. hirsutum, Pers.).

\section{Form difforme.}

Ascigerous portion often bent or irregular in form, compressed, obtuse, slightly viscid when moist; paraphyses septate, apex slightly thickened and often more or less swollen below the septa, curved or slightly wavy.

Syn.-Geoglossum difforme, Fries, Obs. Myc. i, I 59, I8I5; Cooke, Mycogr. 6, fig. 7, 1875; Sacc., Syll. viii, n. I 43, I889; Massee, Brit. Fung.-Flora, iv, 492, 1895 ; Rehm, Kr.-Fl. n. 5873, 1896. 
Geoglossum nigritum, Cooke, Mycogr. 205, fig. 345, I879; Sacc., Syll. viii, n. I45, I889; Rehm, Kr.-Fl. n. 5874, I896.

Clavaria nigrita, Fries, Hymen. Eur. 676, 1874, not of Persoon, Syn. 604.

Exs.-Cooke, Brit. Fung. n. 48 I ; Cooke, Brit. Fung. ed. ii, n. 394 ; Berk., Brit. Fung. n. 256 ; Roumeg., Fung. Gall. n. 2419 ; KlotzschRabenh., Herb. Myc. n. 424.

$H a b$.- On the ground among grass, \&c.

Distr.-Britain, Ireland, France, Belgium, Germany, Sweden, Finland, Italy, Austria, Victoria (Harkaway Range, French), South Carolina.

Specimens from Fries in the Kew Herbarium show that his G. difforme and G. nigritum are identical, and again in a broad sense are identical with $G$. glabrum, differing mainly in the tips of the paraphyses not being so distinctly clavate, and constricted at the septa near the apex. The characteristic clavate form of the spore is present.

As Geoglossum nigritum may be again restored by some one to specific rank, its true history may as well be told, so as to prevent complication in the future. Persoon described a fungus, which he called Clavaria nigrita (Pers., Syn. 604, I801). There seems every reason to believe that this fungus was a genuine Clavaria, as that genus is defined at the present day, and that the description and figure given by Bresadola (Fung. Trident. 62, tab. lxvii, fig. 4) represents Persoon's fungus. Fries quotes Persoon's fungus as Clavaria nigrita, Pers., and gives Persoon's own diagnosis of his species in Syst. Myc. i, 483, I82 I, and Epicr. 578, 1836-38. In Hym. Eur. 676 , 1874, Fries again gives Persoon's name and diagnosis of the fungus under consideration, but adds, 'species insignis, habitu Geoglossi, nuperius ad Halmbyboda prope Upsaliam lecta (v. v.).' Here, for the first time, Fries collected what he supposed to be the Clavaria nigrita of Persoon. A portion of this gathering was sent by Fries to Berkeley, and is now in the Kew Herbarium. This specimen was examined by Cooke, and found to be a Geoglossum, and figured, inaccurately, in Mycogr. 205, fig. 345, r879. Cooke, however, did not doubt this fungus being the Clavaria nigrita, Pers., and figured it as such, on the faith of the species determined by Fries, calling it ' Geoglossum nigritum, Pers.' 


\section{Massee. - A Monograph of the Geoglosseae.}

Var. lignicolum. (Pl. XII, Figs. I, 2.)

Gregarious on rotten wood, 4-5 $\mathrm{cm}$. high, entirely black with a decided purple tinge; ascigerous portion narrowly clavate, about $\frac{1}{3}$ the entire length, about $3 \mathrm{~mm}$. thick, round or compressed, becoming imperfectly hollow, glabrous, dry, passing gradually into the slender, usually crooked, equal, minutely velvety stem. Asci clavate, apex rounded and tinged blue with iodine, often curved, I 5 O $\times$ I $5 \mu$; spores linear-clavate, apex thickest, brown, translucent, usually very slightly curved, 7 -septate, arranged in a parallel fascicle in the ascus, 8 in number, $80-85 \times 5^{-6} \mu$; paraphyses straight, septate, clavate, apex tinged olive and about $6 \mu$ thick.

Syn.-Geoglossum lignicolum, Massee, Journ. Bot. xxxiv, I45, pl. 357, f. $19-20,1896$.

Hab.-On rotten wood.

Distr. - Tasmania (Archer).

Growing on rotten wood along with the type specimen of Mitrula vinosa, Berk., which it resembles superficially.

Having again examined the present fungus, I come to the conclusion that it must be reduced to a variety of $G$. glabrum, differing mainly in the purple tinge of the ascophore, and the less distinctly moniliform paraphyses. The spores are of the characteristic glabrum type.

Geoglossum Peckianum, Cooke, Hedw. I875, p. Io; Cooke, Mycogr. 5, f. 5, I875; Sacc., Syll. viii, n. I47, 1889. (Pl. XII, Figs. 42, 43.)

Gregarious or tufted, black, stem viscid, entire fungus $4-7 \mathrm{~cm}$. high, glabrous; ascigerous portion narrowly lanceolate, somewhat compressed, narrowing below into the stem, but the termination distinctly defined, less than half the length of the entire fungus; stem very minutely squamulose, viscid. Asci narrowly elliptic-fusiform, apex narrowed, pore blue with iodine, about $180-200 \times 18-20 \mu$; spores 8, arranged in a parallel fuscicle in the ascus, clear brownish-umber, translucent, linear-fusoid or subclavate, ends slightly narrowed, sometimes slightly curved, 7 -septate at first, finally $\mathbf{I} 5$-septate at maturity, I I 5-I $25 \times 6-7 \mu$; paraphyses slender, septate, longer than the asci, tips brownish, slightly thickened, variously curved and twisted.

Syn.-Geoglossum glutinosum, Peck, $25^{\text {th }}$ Rep. N. Y. State Mus. 97, 1872, not of Persoon. 
Hab.-Swampy ground.

Distr.-United States (Sandlake and Forestburgh, N.Y., Peck; Gainsville, Fla., Ravenel, n. 89; New England, Murray, n. 5339; Lower Carolina, Curtis, n. I227), England (a specimen from Sowerby's herbarium, now at Kew, called Geoglossum difforme), France (Montmorency, Boudier).

Distinguished among the glabrous species more especially by the paraphyses, which are longer than the asci, and strongly curved or spirally twisted at the thickened, coloured tips. Neglecting the spines, this species is almost indistinguishable from some forms of G. hirsutum.

\section{Form umbratile.}

Scattered or gregarious, elongato-clavate, $3-6 \mathrm{~cm}$. high, $2-3 \mathrm{~mm}$. thick, glabrous, even, longitudinally striate when dry, black. Asci cylindrical, very shortly stipitate, apex obtuse, $160 \times 20 \mu$; spores 8, 2-3-seriate, rod-shaped-fusoid or somewhat clavate, 7 -septate, not constricted, dusky, $80 \times 5 \mu$; paraphyses slender, $4 \mu$ thick, tips pale brown, strongly circinate.

Syn.-Geoglossum umbratile, Sacc., Mich. i, 444, 1879; Sacc., Syll. n. 146,1889 .

Hab. - Swampy ground.

Distr.-Italy (Bizzozero).

As suggested by Saccardo, the present differs from G. Peckianum, mainly in the 7 -septate spores.

\section{Form Barlae.}

Blackish-olive, 3-5 cm. high; ascigerous portion compressed, glabrous, somewhat tongue-shaped, $\mathbf{I}-2 \mathrm{~cm}$. broad; stem paler, blackish furfuraceous at the apex. Hymenium blackish-olive, even, not at all or scarcely viscid in rainy weather, well defined from the stem. Asci fusiform-clavate, base narrowed and wavy, $300-320 \times 18-20 \mu$; spores 8 , umber, linear-clavate, straight or slightly curved, 7 -septate, $85-95 \times 6-7 \mu$; paraphyses brownish, simple or branched at the base, septate, apex incrassated, torulose.

Syn.-Geoglossum Barlae, Boudier, Soc. Mycol. France, iv, 76, I888; Sacc., Syll. viii, in a note under n. 146, 1889 .

$H a b$.-On clay ground among grass.

Distr.-France (Nice, Barla). 


\section{Massee.-A Monograph of the Geoglosseae.}

Again, Boudier considers the present form to be distinguished from G. Peckianum more especially by the 7 -septate spores. The blackisholive, broader ascigerous portion is the only tangible distinction between the present and form umbratile.

Geoglossum pumilum, Winter, Grev. xv, 91, I887 ; Sacc., Syll. viii, n. I $53, \mathbf{1} 889$.

Small, blackish ; ascigerous portion ovate or somewhat deformed, capitate, distinct, slightly and irregularly compressed, perfectly smooth, up to $3 \mathrm{~mm}$. long, and apparently viscid; stem subcylindrical, often slightly compressed and grooved, up to $6 \mathrm{~mm}$. long, furnished with squarrose fascicles of brownish hairs. Asci cylindric-clavate, sessile, 8-spored, $230-255 \times 25^{-27} \mu$; paraphyses filiform, expanding upwards into a thick brownish apex up to Io $\mu$ broad, sometimes septate towards the apex, straight; spores cylindrical, slightly narrowed and rounded at both ends, somewhat curved, generally $\mathbf{I} 5$-septate, very slightly constricted at the septa, brown, 94-1 10 $\times 7 \mu$.

Hab.-On clay ground.

Distr.-Brazil (Sao Francisco, Prov. Sta. Catharina, Ule, n. 338).

The above is Winter's diagnosis of the species.

Geoglossum viscosulum, Sacc., Syll. viii, n. 140, 1889.

Black, viscid, glabrous; ascigerous portion gradually attenuated into the stem, the fertile surface divided into quadrate areolae; these areolae are convex when moist and concave when dry. Asci clavate, apex narrowed; spores 8 , cylindrical, brown, 3-5-septate, somewhat shorter than the ascus; paraphyses septate, apex capitate straight or curved.

Syn.-Cibalocoryne viscosula, Hazsl., Ung. Akad. d. Wiss. xi, 8, $\mathbf{I} 88 \mathrm{r}$.

$H a b .-$ On the ground among moss.

Distr.-Hungary (Hazslinszky).

Apparently a very distinct species, although the diagnosis unfortunately leaves something to be desired. The areolation of the hymenial surface is the most tangible feature mentioned, and, if constant, will afford an easy means for distinguishing the species, or may even prove to be of generic value, thus forming a connecting link with the Morchella group; but until the species is better known, it is perhaps best in Geoglossum, as placed by Saccardo. A more or less 
Massee.-A Monograph of the Geoglosseae. 253

alveolate condition of the hymenium occurs in Mitrula Rehmii and M. muscicola.

Geoglossum Heuflerianum, Bail, Herb. Mycol. typ. n. I80 b (without a diagnosis) ; Sacc., Syll. viii, n. ז39, r889; Rehm, Krypt.Flora, n. $5869, \mathbf{1} 896$.

Very small, clavate, black, 3-4 $\mathrm{mm}$. long; spores terete-fusoid, rounded at both ends, almost straight, $45-50 \times$ io $\mu, 3$-septate, dusky; paraphyses moniliform at the apex.

Hab.-Among moss.

Distr.-Mutters, Tirol.

Remarkable for the very small size of the ascophore, and the 3 -septate, thick spores. The above is the diagnosis given by Saccardo (Syll. viii, n. I39).

\section{Spathularia, Persoon.}

Erect, stipitate ; ascigerous portion obovate, spathulate, or elliptical, more or less hollow, laterally compressed, glabrous, decurrent down opposite sides of the stem, from which it is sharply differentiated. Asci clavate, apex narrowed; spores 8 , arranged in a parallel fascicle in the ascus, elongated filiform-clavate, hyaline, multiguttulate then multiseptate; paraphyses present.

Spathularia, Persoon, Tent. Disp. meth. Fung. 36, 1797; Fries, Syst. Myc. i, 490, I82 I ; Sacc., Syll. viii, 48, I889; Massee, Brit. Fung.-Flora, iv, 485, I 895 ; Rehm, Krypt.-Flora (Discom.), I I 58, I 896 .

Spathulea, Fries, Plantae Homon. 86, 1825. 'Spathularia; quod nomen paululum mutandum ob animal homonymon' (Fries, l. c.).

Clavaria, Elvella, Mitrula, and Leptoglossum in part, of authors.

Closely resembling the genus Mitrula in general appearance and habit, but in the last-named the spores are much shorter and broader, and 2 -seriate in the ascus. The only other genus having very long, linear spores arranged in a parallel fascicle in the ascus is Vibrissea, but here the ascigerous portion is pileate or horizontal, the margin free and incurved; the upper surface covered with the hymenium, the under surface sterile. In Spathularia the ascigerous portion is adnate to the stem throughout, and every part is covered with the hymenium. 


\section{Massee.-A Monograph of the Geoglosseae.}

Distr.-A small genus of six species, confined to the North Temperate Zone. S. rufa, S. Neesii, S. nigripes, and S. clavata occur in Europe; the last-named species also occurs in the United States, while $S$. flava is confined to the last-named country.

\section{Key to THE SPECIES.}

I. Stem white or yellow.

clavata. Ascigerous portion broadly obovate.

flava. Ascigerous portion narrowly elliptic-oblong.

\section{Stem dark-coloured.}

* Stem minutely velvety.

velutipes.

** Stem glabrous.

nigripes. Stem violet-brown.

rufa. Ascigerous portion obovate, margin even, powdered with lilac meal.

Neesii. Ascigerous portion spathulate or sphaeroid, margin wavy.

Spathularia clavata, Sacc., Mich. ii, 77, I882; Sacc., Syll. viii, n. 160,1889 ; Massee, Brit. Fung.-Flora, iv, 485, figs. $22-24$ on p. I88; Rehm, Krypt.-Fl. n. 5877 , figs. I-4 on p. I 46 , 1896 . (Pl. XIII, Figs. 50-53.)

Gregarious or in small clusters, entire fungus $3-10 \mathrm{~cm}$. high, dry; ascigerous portion spathulate or broadly clavate, obtuse, or sometimes more or less cleft at the apex, laterally compressed, surface wavy or somewhat lacunose, margin crisped or undulated, running down the stem for some distance on opposite sides, hollow, clear yellow, rarely with a tinge of red, $2-4 \mathrm{~cm}$. high, $\mathrm{I}-2 \cdot 5 \mathrm{~cm}$. broad; stem $\frac{1}{2}-\mathrm{I} \mathrm{cm}$. thick, often thickened at the base, hollow, white, often becoming yellowish. Asci clavate, apex narrowed, pore blue with iodine, I00-I $40 \times 12-15 \mu$; spores 8 , arranged in a parallel fascicle in the ascus, hyaline, filiform-clavate, base narrowed, multiguttulate then multiseptate, enclosed in a mucilaginous sheath, often slightly bent, 
$5^{\circ-6} 5 \times 3 \mu$; paraphyses very slender, septate, often branched, the unthickened tips more or less curved.

Syn.-Elvella clavata, Schaeffer, Icon. Fung. ii. tab. I49, I 773 .

Helvella spathulata, Afzelius, Vet. Acad. Handl., I 775.

Clavaria spathulata, Mull., Flor. Dan. tab. 658, I 775 .

Helvella feritoria, Bolton, Hist. Fung. tab. 97, I 789 .

Spathularia flavida, Persoon, Tentamen Disp. meth. Fung. 36, I 797 ; Cooke, Mycogr. 203, f. 342, 1878; Phil., Brit. Disc. 30, pl. ii, f. 7,1887 .

Helvella spathularia, Sowerby, Eng. Fung. tab. 97, I789.

Spathularia flava, Swartz, Vet. Akad. Handl. ro, I8I 2.

Spathularia flavida, $\boldsymbol{\beta}$ crispa, Corda, Icon. ii, tab. I 5, f. I25, 1838 .

Mitrula spathulata, Fries, Summa Veg. Scand. $5^{8} 3, \mathbf{1} 846$.

Spathularia flavida, P., var. plicata, Thümen, in Thüm., Fung. Austr. n. 925 .

Exs.-Sydow, Myc. March. n. 25 6 ; Flor. Exs. Austro-Hung. n. 1947 ; Ellis, N. Amer. Fung. n. I 268 ; Schweiz. Krypt. n. 2 I 5 ; Fuckel, Fung. Rhen. nn. I I43, 2484; Klotzsch-Rabenh., Herb. Myc. n. 28 ; Roum., Fung. Sel. Gall. n. 326 ; Karsten, Fung. Fenn. n. I 40 ; Thümen, Fung. Austr. n. 925 ; Jack, Leiner, u. Sitzenb., Krypt. Badens, n. 337 ; Cooke, Fung. Brit. n. 470 ; Phil., Elv. Brit. n. 3 ; Rab., Fung. Eur. n. 126, Holl, Schmidt, and Kunze, Deutschl. Schw. n. cxciv ; Rehm, Ascom. n. 426 ; West. and Wall., n. 1085; Berk., Brit. Fung. n. 257 ; Desmazières, Crypt. France, sér. 2, n. 455 ; Sacc., Myc. Ven. n. 168.

Hab.-Britain, Portugal (Henriquez), France, Belgium, Norway, Sweden, Germany, Austria, Switzerland, Italy, Finland, United States (Maine, Fuller, n. 22).

Very variable in size, the smaller forms sometimes closely resembling large specimens of Mitrula laricina.

Spathularia flava, Massee (non Swartz). (Pl. XII. Figs. 25, 26.)

Gregarious ; ascigerous portion narrowly elliptic-oblong or narrowly elliptical, laterally compressed, grooved, showing a tendency to be decurrent down opposite sides of the stem, from which it is sharply differentiated at the base, about $2 \mathrm{~cm}$. long, 5-7 $\mathrm{mm}$. wide, pale primrose-yellow; stem equal, or slightly thickened at the summit, a little paler in colour than the fertile portion, and about equal to it in length. Asci clavate; spores arranged in a parallel fascicle, 


\section{Massee.-A Monograph of the Geoglosseae.}

narrowly cylindrical, 8-10-septate, almost as long as the ascus; paraphyses not seen.

Syn.--Geoglossum flavum, Gillet, Disc. France, 24, with a fig., I 879.

Leptoglossum flavum, Sacc., Syll. viii, n. I 59, I 889.

Hab.-Among moss.

Distr.-France.

Spathularia velutipes, Cooke and Farlow, Grev. xii, 37, 1883; Farlow, Appalachia, iii, 245, I884; Sacc., Syll. viii, n. I64, I889. (Pl. XIII, Figs. 85-88.)

Gregarious, entire fungus $3-5 \mathrm{~cm}$. high; ascigerous portion spathulate, even, margin somewhat wavy, laterally compressed, decurrent down opposite sides of the stem, hollow, $\mathbf{I} \cdot 5^{-2} \mathrm{~cm}$. high, $\mathbf{I}-\mathbf{I} \cdot 5 \mathrm{~cm}$. wide, tawny yellow; stem hollow, nearly equal, minutely velvety, dark brown with an orange tinge. Ascus clavate, apex narrowed, not blue with iodine, 85-100 $\times$ I0-II $\mu$; spores 8, arranged in a parallel fascicle, filiform-clavate, apex only slightly thicker than the base, slightly curved, multiguttulate, $55-60 \times 1 \cdot 5 \mu$; paraphyses numerous, cylindrical, septate, not thickened at the strongly curved tips, $2 \mu$ thick.

Exs.-Ellis and Everh., N. Amer. Fung. ser. 2, n. 2029.

Hab.-On mossy trunks in damp woods.

Distr.-United States (White Mountains and Lake Willoughby, Vt., Farlow).

This species is common in the region of the White Mountains and Lake Willoughby, Vt., and has been found also in other States. It has generally been named by American collectors Spathularia flavida, but it differs widely from that species. The substance is firm and even tough, and specimens shrink comparatively little in drying. The fungus is seldom more than two inches high, and the stipe is of a dark velvety brown, while the hymenium is somewhat yellow, but never of the bright yellow colour of S. flavida (Farlow, l.c.).

A note on the label accompanying the specimens sent to Cooke by Professor Farlow reads as follows: 'This is a common Spathularia in the colder parts of New England, where it grows on mossy $\operatorname{logs}_{\mathrm{s}}$ in places which are somewhat moist, but not very wet. The dried specimen gives a good idea of the habit and colour when fresh, as it changes very little in drying.' 


\section{Massee. - A Monograph of the Geoglosseae.}

Distinguished from all known species by the dark velvety stem. The spores are thinner than in $S$. flavida, and I have not been able to demonstrate the existence of an investing mucilaginous sheath ; this however is best seen in fresh specimens, and is of no specific value.

Type specimen examined.

Spathularia nigripes, Sacc., Syll. viii, n. I6 1, I889.

Ascigerous portion ovoid-oblong, I cm. long, laterally compressed, rugose, undulate, yellowish or flesh-colour, apex rosy or rufescent ; stem cylindrical or compressed, I $\mathrm{cm}$. long, base inflated, slightly rugulose, glabrous, violet-brown; flesh soft, white, smell pleasant; spores acicular, $5 \circ \mu$ long, guttulate, hyaline.

Syn.-Mitrula nigripes, Quélet, Suppl. xi, I I, tab. vii, f. 3 , Assoc. Franç., I 883 .

Hab.-Caespitose or scattered in sandy woods.

Distr.-Maritime Alps (Barla).

Quélet suggested that the present species was allied to Mitrula $r u f a$, but this resemblance is superficial only. Saccardo, on the other hand, thinks it may be Spathularia crispata, forma spathulata of Fuckel, Symb. Myc., Append. ii, 66. This again is meaningless, as no one has any idea as to what $S$. crispata is, since it was never described nor figured.

Spathularia rufa, Swartz, Vet. Akad. Handl. I8I2, p. I I ; Cooke, Mycogr. 204, fig. 343, I878; Sacc., Syll. viii, n. I62, I889; Rehm, Kr.-Fl. n. 5879 , I 896 ; not of Nees, Syst. I 7 I, tab. xvii, f. I 56 B. I I.

Gregarious, entire fungus $\mathbf{I}-4 \mathrm{~cm}$. high; ascigerous portion obovate, even, margin not crisped nor wavy, laterally compressed, decurrent down opposite sides of the stem, about $\mathbf{I} \mathrm{cm}$. high and $5-7 \mathrm{~mm}$. broad, dingy rufous-orange, more or less powdered with lilac meal; stem terete, usually more or less thickened at the base, reddish brown or bay. Asci clavate, apex narrowed, not blue with iodine, I00-I $30 \times$ IO-I $2 \mu$; spores 8 , arranged in a parallel fascicle, filiform-clavate, apex thickest, straight or slightly curved, multiguttulate then multiseptate, $60-70 \times 2 \mu$; paraphyses slender, septate, sometimes branched, tips often curved, about $2 \mu$ thick.

Syn.-Mitrula lilacina, Quélet, Enchir. 269, I 886. 


\section{Massee.-A Monograph of the Geoglosseae.}

Exs.-Rabenh., Fung. Eur. n. 235 (called Spathulea rufa, Nees); Roum., Fung. Gall. Exs. n. 2075 .

$H a b$.- On the ground in woods and shady places.

Distr.-Germany, France.

Distinguished from allies by its smaller size, dingy orange-brown colour, and in having the ascigerous portion even, and more or less powdered with lilac meal. A very fine series of specimens of this species are in the Kew Herbarium, having the following on the paper on which they are mounted: 'Spathulea bulbosa, Rud. Herb. Neuhoff, Mecklenburg-Strelitz, in pinetis. Dr. F. Rudolphi.'

Spathularia Neesii, Bres., Fung. Trident. 66, tab. lxxii, fig. 3 , I881 ; Sacc., Syll. viii, n. 163, I889; Rehm, Kr.-Fl. n. 5878, I896.

Ascigerous portion ovoid, sphaeroid, or spathulate, laterally compressed, decurrent down opposite sides of the stem, even or rugulose, margin wavy, gelatinous-fleshy, whitish tan then lurid ochraceous, somewhat egg-yellow when dry, $\mathbf{I} \cdot 5^{-2} \mathrm{~cm}$. high, I-I.5 $\mathrm{cm}$. broad; stem roundish or somewhat compressed, even, becoming rugulose, glabrous, ochraceous-fuscous, apex paler, stuffed, $\mathbf{r} \cdot 5^{-2} \mathrm{~cm}$. long, 3-4 $\mathrm{mm}$. thick; flesh similarly coloured, inodorous, slightly acid. Ascus fusoid-clavate, not blue with iodine, I IO-I 50 $\times$ I2-I $8 \mu$; spores filiform-clavate, apex thickest, multiguttulate, slightly curved, tinged yellow, $60-80 \times \mathbf{I} \cdot 5^{-2} \cdot 5 \mu$, with an outer mucilaginous coat, tinged yellow, 8 in an ascus, arranged in a parallel fascicle; paraphyses numerous, branched, filiform, tips curved, about $2 \mu$ thick.

Syn.-Spathularia rufa, Nees, Syst. I 7 I, tab. xvii, f. I 56 B. (not of Swartz nor Cooke); Pers., Myc. Eur. i, I 98 ; Gillet, Disc. France, 26 , with fig.

Spathularia rufa, var. badipes, Pat. Tab. Anal. Fung. 7o, f. I6r.

Mitrula rufa, var. Quél. xi, Suppl. p. I 9.

$H a b$. - On pine leaves, \&c., densely gregarious.

Distr.-Germany, France, Italy.

Bresadola has shown that the fungus called Spathularia rufa by Nees is not the fungus so called by Swartz, and further considers that the fungus described above is the one Nees had in view. The above description and synonymy is from Bresadola. 


\section{VIBRISSEA, Fries, emend.}

Stipitate, vertical; ascigerous portion pileate, horizontal, margin thick, incurved towards the stem, upper surface fertile, under surface sterile, glabrous; stem simple, central. Asci narrowly elongatoclavate, apex narrowed, pore not blue with iodine; spores 8 , needleshaped, hyaline, multiguttulate, sometimes becoming multiseptate, arranged in a parallel fascicle in the ascus; paraphyses very slender, sometimes branched and the tips curved, septate.

Vibrissea, Fries, Syst. Myc. ii, 3 I, I 823 .

Leotia, Hill, Hist. Pl. 43, I 75 I, in part.

Cudonia, Fries, Summa Veg. Scand. 348, 1846, in part.

Helotium of old authors, in part.

Superficially resembling Leotia in the ascigerous portion or pileus being horizontal or pileate, with a free, incurved margin, and in having an elongated stem, but differing in having needle-shaped spores arranged in a parallel fascicle in the ascus. Several sessile or subsessile species that have been included in the present genus by different authors, are here excluded on account of the presence of a more or less distinctly parenchymatous cortex, and absence of the characteristic margin incurved towards the stem. $V$. truncorum is a truly aquatic fungus, and at maturity the needle-shaped spores escape partly from the asci and vibrate in the water, hence the generic name.

Distr.-A small genus containing four well-defined species confined to the North Temperate Zone. $V$. truncorum and $V$. circinans occur in Europe and the United States; $V$. lutea and $V$. ochroleuca are confined to the last-named country. Of the two doubtful species, $V$. vermicularis is recorded from European Russia, and $V$. rimarum from Kamtschatka.

\section{KEY TO THE SPECIES.}

I. Stem minutely velvety or squamulose.

truncorum. Pileus deep orange-red.

II. Stem glabrous.

circinans. Pileus pale yellowish flesh-colour, under surface wrinkled, the ridges running down the apex of the stem.

lutea. Pileus and stem yellow.

ochroleuca. Pileus ochraceous-white; stem white. 


\section{Massee.-A Monograph of the Geoglosseae.}

Vibrissea truncorum, Fries, Syst. Myc. ii, 31, 1823; Phil., Brit. Disc. 316, pl. x, f. 6o, I887; Phil., Trans. Linn. Soc. (Bot.), ser. 2, ii, 5, pl. I, f. I-9, I88I ; Sacc., Syll. viii, n. I67, I889; Rehm, Kr.-Fl. n. 5888, I896; Massee, Brit. Fung.-Fl. iv, 487, figs. $32-35$, p. I88, I895. (Pl. XII, Figs. I5-I7a.)

Gregarious or scattered, often in clusters of $2-3$ specimens, entire fungus $\mathrm{I}-2 \mathrm{~cm}$. high; ascigerous portion rather fleshy, orbicular, slightly convex, margin thick, free, and inclined to be incurved, disk glabrous, even, usually clear orange-red, sometimes yellow or brownish red, minutely silky with the protruding spores at maturity, 3-5 $\mathrm{mm}$. across; stem 6-I $5 \mathrm{~mm}$. long, $\mathbf{I} \cdot 5-3 \mathrm{~mm}$. thick, round, almost equal throughout, densely covered with coloured obtuse-septate hyphae spreading at right angles to the stem; when these hyphae are arranged in clusters the stem appears to be minutely squamulose, varying in colour from white to pale grey, brownish, or with an olive tinge. Asci very long, narrowly cylindrical, apex slightly narrowed, not blue with iodine, $225^{-2} 5^{\circ} \times 6 \mu$; spores 8 , filiform, hyaline, multiguttulate then multiseptate, $200 \times \mathbf{I} \mu$, arranged in a parallel fascicle in the ascus paraphyses very slender, sometimes branched, tips slightly thickened and often tinged yellow.

Syn.-Leotia truncorum, Alb. and Schz., Consp. Fung. Nisk. 297, tab. 3, f. 2, 1805; Pers., Myc. Eur. i, 199, 1822.

Leotia clavus, Pers., Myc. Eur. i, 200, tab. xi, fig. 9, I822.

Vibrissea Margarita, White, Scottish Nat. ii, 2 I8, 1874; Phil., Brit. Disc. 3 I 7 ; Phil., Trans. Linn. Soc. (Bot.), ser. 2, ii, 6, pl. I, f. Io-I6, I 88 I ; Sacc., Syll. viii, n. I 70, I889.

Vibrissea truncorum, Fr., var. albipes, Peck, $44^{\text {th }}$ Rep. N.Y. State Mus. 37, I89 I.

Exs.-Phil., Elv. Brit. n. 4 and 4 bis; Roumeg., Fung. Sel. Gall. n. $53^{6}$; Desm., Crypt. France, sér. I, n. $830 ;$ Moug. and Nest., Stirp. Crypt. n. $78 \mathrm{I}$; Ellis, N. Amer. Fung. n. I34.

Hab.-On decaying and submerged wood, branches, and leaves, principally in subalpine districts.

Distr.-England, Scotland, Wales, France, Germany, Italy, Hungary (Hazslinszky), Finland, Belgium, Switzerland (Gadmenthal, G. Nicholson), Portugal (Henriquez), United States (New England, Sprague; N. Jersey, Ellis ; Cascade Mountains, Dr. Lyall).

A truly aquatic fungus, completing its entire development only when entirely submerged, and attaining the largest size and most brilliant 


\section{Massee.-A Monograph of the Geoglosseae. 26I}

colour when occurring in alpine streams. Very beautiful specimens were found by Mr. G. Nicholson, Curator of the Royal Gardens, Kew, in a small stream in the Gadmenthal, opposite Feldmoos, Switzerland, in September, I896. Peck's var. albipes is nothing more than the typical form, which was originally described and figured by Albertine and Schweinitz as having a white stem. When removed from the water in which it grows, every part of the fungus becomes darker in colour.

Vibrissea circinans, Hazsl., Rendh. Köggornbák, in Ung. Akad. d. Wiss. xi, I5, 1881. (Pl. XII, Figs. I3, 14.)

Gregarious, often growing in circles; ascigerous portion fleshy, somewhat viscid when moist, pileate, convex, becoming more or less irregular, margin incurved, usually wavy; under surface concave, minutely wrinkled, the ridges often running down the stem, glabrous, pale yellowish flesh-colour or yellowish, $\mathbf{I}-2 \cdot 5 \mathrm{~cm}$. broad ; stem $2-6 \mathrm{~cm}$. long, often crooked, imperfectly hollow, cylindrical or thickened above or below, pallid or reddish, pulverulent, glabrous. Asci clavate, apex rather acutely narrowed, pore not blue with iodine, $150-180 \times 10-12 \mu$; spores 8 , arranged in a parallel fascicle, linear-clavate, often slightly curved, at first multiguttulate, then multiseptate, 50-60 $\times 2 \mu$; paraphyses filiform, sometimes branched, tips not thickened, often curved.

Syn.--Leotia circinans, Pers., Comm. Fung. Clav. 3 I, I 797 ; Pers., Icon. et Descr. I6, t. 5, f. 5-7, I 798-1800; Fries, Syst. Myc. ii, 27 , I 823 ; Cke., Mycogr. 97, fig. I 72, 1879; Phil., Brit. Disc. 24, pl. ii, f. $5, \mathbf{1} 887$.

Helotium circinans, Swartz, Vet. Akad. Handl. p. I 5, I 8 I 2.

Cudonia circinans, Fries, Summa Veg. Scand. 348, I846; Rehm, Kr.-Fl., n. 5887, 1896; Sacc., Syll. viii, n. 165, I 889 .

Leotia gracilis, Pers., Myc. Eur. i, I 98, I 722.

Helvella revoluta, Wahlb., Fl. Upsal. $464, \mathbf{1} 820$.

Exs.-Rabenh., Fung. Eur. n. $3^{8}$ and $3^{\text {I } 2}$ (called Podonia circinans (Pers.), Fries, Mspt.); Karst., Fung. Fenn. n. I53; Thüm., Myc. Univ. n. I809; Fckl., Fung. Rhen. n. I I 39; Roum., Fung. Sel. Exs. $473^{8 .}$

Hab.-Among moss, \&c., in woods, chiefly pine.

Distr.-Britain, France, Portugal, Sweden, Norway, Germany, Bohemia, Austria, Finland, Lapland, United States. 


\section{Massee.-A Monograph of the Geoglosseae.}

Most closely allied to Vibrissea lutea, Peck, under which species the two are compared.

Specimens from Persoon examined.

Vibrissea lutea, Peck, 25th Rep. N. Y. State Mus. 97, pl. i, figs. 19-23, 1872. (Pl. XII, Figs. 5-7.)

Gregarious, $\mathbf{I} \cdot 5^{-2} \cdot 5 \mathrm{~cm}$. high; ascigerous portion subglobose, smooth, margin often lobed, inflexed, free, concave below, 4-8 $\mathrm{mm}$. across, yellow ; stem nearly equal, even, smooth, solid, longitudinally wrinkled when dry, rather deep yellow. Asci clavate, apex rather acutely narrowed, not blue with iodine, II $5^{-\mathbf{I}} 30 \times \mathbf{I} 2 \mu$; spores 8 , arranged in a parallel fascicle in the ascus, filiform and slightly thickened near the apex, often multiguttulate, $80-90 \times \mathbf{I} \cdot 5 \mu$; paraphyses numerous, delicately septate, not thickened at the strongly curved tips, hyaline, longer than the asci, about $2 \mu$ thick.

Syn.-Cudonia lutea, Sacc., Syll. viii, n. 166, I889.

Hab.-Prostrate, mossy trunks of trees and among fallen leaves in woods.

Distr.-United States (North Elba, Peck).

Specimen from Professor Peck examined. The spores often contain a row of oil-globules, and in some instances there are indications of septa.

Cooke, in Mycogr. 97, has quoted this species as a synonym of his Leotia circinans (Vibrissea circinans, Hazsl.); this however is a mistake, the present species being quite distinct in the longer spores and form and colour of the ascophore.

Vibrissea ochroleuca, Massee. (Pl. XIII, Figs. 70-72.)

Scattered, somewhat gelatinous, entire fungus $2 \cdot 5-3 \mathrm{~cm}$. high; ascigerous portion pileate, fleshy, undulate, margin involute, pale ochraceous, glabrous, up to I cm. across; stem about $2.5 \mathrm{~cm}$. high and $3 \mathrm{~mm}$. thick, glabrous, white, rather flexuous. Asci clavate, apex narrowed, not blue with iodine, narrowed below into a long, slender pedicel, 100-1 10 $\times 8-9 \mu$; spores 8, filiform, hyaline, slightly curved, at first 3 -septate, then 5 -7-septate, $25-30 \times 2 \mu$, arranged in a parallel fascicle in the ascus; paraphyses very slender, septate, often branched, tips not thickened.

Syn.-Leotia ochroleuca, Cooke and Harkness, Grev. ix, 8, I880; Sacc., Syll. viii, n. 25 I5, I889.

Hab.-On damp ground. 
Distr.-California (Harkness, n. I37I).

Most nearly allied to Vibrissea circinans, from which it is distinguished by the shorter spores and pure white stem.

Type specimens examined.

\section{Doubtful Species.}

Vibrissea vermicularis, Weinmann, Hym. Gast. Ross. 487, I 836 .

Simple, capitulum suborbicular, sublacunose, watery-pallid; stem subterete, blackish-brown.

Gregarious, stipes firmly attached, replete with a gelatinous mass when young, becoming partly hollow with age, generally cylindrical (very rarely attenuated towards the base or compressed), straight or curved, tough, smoky-black, paler below the pileus. Pileus $\frac{1}{2}-2$ lines broad, watery-pallid when young, then slightly tinged with blue.

Hab. - On damp rotten wood of Aluus incana?

Distr.-Russia.

Vibrissea rimarum, Fries, Syst. Myc. ii, 32, 1823; Sacc., Syll. viii, n. $169, \mathbf{1} 889$.

Subfasciculate; yellow, head becoming tawny, stem compressed.

Allied to the previous one [ $V$. truncorum $]$, but truly distinct. Entire fungus, from the peculiar habitat, much compressed; stem I inch long, thickness variable, flexuous, somewhat connate at the base. Cap hemispherical, small in proportion, becoming rufous, otherwise the entire fungus is yellow (Fries).

$H a b$. - In cracks in old rotten worked beams.

Distr._Kamtschatka (Wormskiold).

\section{Mitrula, Fries, emend.}

Ascophore erect, black or bright coloured, dry, or in some species slightly viscid when moist; ascigerous portion clavate, subspathulate, or globose, often laterally compressed, and showing a distinct tendency to become decurrent down opposite sides of the stem, from which it is sharply differentiated, glabrous; stem sometimes squamulose or pulverulent. Asci narrowly cylindric-clavate, apex narrowed or obtuse, pore blue with iodine in some species, not coloured in others; spores hyaline, narrowly elliptical, septate, rarely continuous, 2 -seriate, rarely $\mathbf{I}$-seriate; paraphyses present. 


\section{Massee.-A Monograph of the Geoglosseae.}

Mitrula, Fries, Syst. Myc. i, 49 I, I82 I.

Geoglossum, Pers., Obs. Myc. i, I I, I 796, in part.

Microglossum, Sacc., Consp. Gen. Disc., Bot. Centralb. xviii, 2 I 4 , I 884, in part.

Leptoglossum, Cooke, Mycogr. 250 (as a subgenus), $\mathbf{1 8 7 9}$; as a genus, by Saccardo, Consp. Gen. Disc., in Bot. Centralb. xviii, 2 I 4 , I884, in part.

Verpa, Swartz, Vet. Ak. Handl. 129, I815, in part.

Clavaria, in part, by old authors.

The present genus closely resembles in general appearance and habit Geoglossum and Spathularia, but differs from both in the much shorter, hyaline, elliptical spores being arranged in a 2 -seriate or I-seriate manner in the ascus. Mitrula laricina often grows on heaps of dead leaves that are floating in water. Leotia has similar spores, but the ascigerous portion is pileate, with a free margin incurved towards the stem.

Distr.-The twenty-five species included in the present genus have collectively a wide area of distribution, extending from Greenland to Tasmania, although with one exception- $M$. rufa-being absent from the tropics. The following fifteen, which constitute more than half the known species, are, so far as is known, confined to Europe :M. purpurascens, Saccardoa, olivacea, lutescens, vitellina, pusilla, sphaerocephala, gracilis, sclerotipes, muscicola, Rehmii, multiforme, globosa, sclerotiorum, arenaria. The following also occur in Europe and other countries:-M. serpentina, laricina, cucullata, microspora. The United States has six species, two of which-M. elegans and luteola-are not known from elsewhere. One species only is peculiar to the southern hemisphere-M. Berterii-having been collected in Juan Fernandez, Tasmania, and New Zealand.

\section{Key to THE SPECIES.}

\section{Pileus with a distinct purple tinge.}

purpurascens. Plant 4-6 cm. high; every part blackish or blackish-brown, with a distinct purple tinge.

Berterii. Plant about $2 \mathrm{~cm}$. high, slender; every part dark coloured, with a purple tinge. 
Massee.-A Monograph of the Geogiosseae. 265

Saccardoa. Plant $7-8 \mathrm{~cm}$. high; apex of pileus purplish, remainder of plant whitish.

\section{Pileus dark green or ochraceous-olive.}

serpentina. Entire fungus dingy green; stem minutely squamulose.

olivacea. Entire fungus dingy green; stem glabrous, base whitish.

(There is a purplish-coloured variety of this species.)

lutescens. Entire fungus pale ochraceous-olive except base of stem, which is green.

\section{Pileus clear yellow to orange.}

laricina. Pileus broadly ovate or subglobose, egg-yellow.

vitellina. Pileus cylindrical, apex narrowed, egg-yellow.

elegans. Entirely pale yellow; stem slender, elongated, glabrous.

luteola. Entirely pale yellow; stem short, distinctly tomentose.

IV. Pileus tawny-yellow, brown, or bay.

rufa. Entire fungus $4-6 \mathrm{~cm}$. high ; rufous to dingy yellow. cucullata. Entire fungus $\mathrm{I}-2 \mathrm{~cm}$. high; head irregularly obovate, stem dark brown, crooked.

pusilla. Entire fungus $\frac{1}{2}-1 \mathrm{~cm}$. high; head clavate or subglobose; stem yellow, usually crooked. Growing on dead leaves of Pinus silvestris.

sphaerocephala. Entire fungus under I $\mathrm{mm}$. high ; head globose, stem straight. Growing on dead pine leaves.

gracilis. Entire fungus $2-2.5 \mathrm{~cm}$. high; head orangebrown; stem wavy, flesh-colour.

sclorotipes. Entire fungus rusty-yellow, I-2 cm. high; stem springing from a small yellowish sclerotium.

muscicola. Entire fungus I-I.5 cm. high; head subglobose, rugulose towards the base; stem yellow.

Rehmii. Entire fungus $2-3.5 \mathrm{~cm}$. high; head obovate, with longitudinal ribs; stem white, then yellowish. 


\section{Massee.-A Monograph of the Geoglosseae.}

bicolor. Entire plant about $6 \mathrm{~cm}$. high; head narrowly lanceolate, brown; stem wavy, channelled.

multiforme. Fungus $\mathrm{I}-2 \mathrm{~cm}$. high ; pileus clavate, capitate, or pileate, dingy brown; stem whitish.

globosa. Plant $3-5 \mathrm{~cm}$. high; head globose; stem slender, every part dark bay.

\section{Entirely whitish or pallid.}

sclerotiorum. About $\mathrm{I} \mathrm{cm}$. high; springing from a sclerotium.

\section{Plant entirely black.}

microspora. Plant $3-6 \mathrm{~cm}$. high ; stem not tinged olive. arenaria. Plant $2-4 \mathrm{~cm}$. high; stem squamulose, tinged olive.

partita. Ascigerous portion tongue-shaped, more or less divided.

Mitrula purpurascens, Massee. (Pl. XII, Fig. 27.)

Caespitose or gregarious, entire fungus $3-6 \mathrm{~cm}$. high, dry, every part blackish or blackish-brown, with a distinct reddish-purple sheen, becoming almost black when dry, imperfectly hollow, flesh dingy purple; ascigerous portion glabrous, variable in form, cylindric-ovate, clavate, or irregularly lobed and deformed, often laterally compressed, $\mathbf{I}-\mathbf{2} \mathrm{cm}$. long, up to $\mathbf{I} \mathrm{cm}$. broad, often much smaller; stem subcylindrical, minutely squamulose. Asci clavate, apex narrowed, pore blue with iodine, $80-100 \times 10 \mu$; spores 8 , irregularly 2 -seriate above, I-seriate below, hyaline, smooth, 3-5-guttulate, and becoming 3 -septate, narrowly cylindric-fusoid, ends narrowed, often slightly curved, 24-30 $\times 5 \mu$; paraphyses slender, septate, tips clavate, brownish.

Syn.-Geoglossum purpurascens, Persoon, Comm. Fung. Clav. 39, I 797 .

Geoglossum atropurpureum, Pers., Obs. Myc. ii, 62, t. 3, f. 5, I 799; Fries, Syst. Myc. i, 490, I82 г ; Cke., Mycogr. Iо, f. I6, I879.

Clavaria mitrata, Holmsk., Fung. Dan. i, 2 I, with an excellent fig., I 799 . 
Mitrula glabra, Karst., Myc. Fenn. i, 30, I87 I.

Microglossum atropurpureum, Karst., Rev. Mon. I 10, I885; Sacc., Syll. viii, n. 130, I889; Rehm, Kr.-Fl. n. 5867, I896.

Geoglossum Hookeri, Cooke, Hedw. I875, 9; Cke., Mycogr. ıо,

f. 15,1875 .

Microglossum Hookeri, Sacc., Syll. viii, n. I 28, I889.

Exs.--Karsten, Fung. Fenn. n. 448.

$H a b$.-On the ground among grass, \&c.

Distr.-Britain, France, Germany, Sweden, Finland, Denmark, Russia.

Stem fibrillose or squamulose, firm, paler, club sometimes terete, sometimes compressed or bifid, and, especially in late autumn, ventricose and deformed, distinct from the stem (Fries).

Most authors hitherto have considered the fungus described above as being the species called Clavaria atropurpurea, Batsch (Elench. Fung. pp. I 33 and 179 , tab. xi, f. 47, I 783). There is a general superficial resemblance certainly to the single specimen figured by Batsch, and this resemblance has been accepted as sufficient evidence; whereas, if the authors had taken the trouble to read Batsch's diagnosis of his species, they would have found that he says, 'substantia lignosa-suberosa, alba'; a statement which does not at all agree with the structure of the fungus under consideration. Furthermore, Batsch cites Micheli, pl. lxxxvi (obviously a slip for pl. lxxxvii), fig. 2, which represents Clavaria pistillaris. Finally, although Batsch's figure shows a purple tinge (in some copies), it is described as 'fulvo-atra.' In all probability Batsch's figure represents some Clavaria near to, if not identical with, $C$. pistillaris. On the other hand, the fungus described above is certainly Geoglossum purpurascens, Pers. (Comm. Fung. Clav. 39, I 797), and the above diagnosis is drawn up from specimens thus named by Persoon himself, and now in the Kew Herbarium.

The species called Geoglossum Hookeri, by Cooke, was founded on a single specimen without locality in the Hookerian Herbarium at Kew, and was described as being black, which is true of the dry state. The structure is identical with that of Mitrula purpurascens, which is also black when dry. Cooke was mistaken in describing his G. Hookeri as having two kinds of paraphyses; the presumed large ones being simply immature asci, which show clearly the apical pore blue when treated with iodine. 


\section{Massee.-A Monograph of the Geoglosseae.}

Mitrula Berterii, Montag., Ann. Sci. Nat. sér. ii, t. 3, 35 I, I 835 ; Mont., in Flor. Chil. (Crypt.) 397, Atlas, pl. 8, f. 5, 1850; Sacc., Syll. viii, n. II 7, I889; Cke., Mycogr. I04, fig. 180, 1876. (Pl. XII, Figs. 33-35.)

Gregarious, entire fungus $2-4 \mathrm{~cm}$. high ; ascigerous portion narrowly cylindrical, both ends slightly narrowed, glabrous, blackish brown with a tinge of purple, 7-r $4 \mathrm{~mm}$. long, about $2 \mathrm{~mm}$. thick; stem similarly coloured to the fertile portion, and a little thinner, straight or flexuous. Asci narrowly cylindric-clavate, apex slightly narrowed, pore blue with iodine, $70-80 \times 5 \mu$; spores 8 , obliquely I-seriate, or inclined to be 2-seriate upwards, hyaline, continuous, smooth, usually slightly curved, linear-elliptic, $7-\mathbf{1 0} \times \mathbf{r} \cdot 5^{-2} \mu$; paraphyses slender, tips slightly clavate and tinged with brown or red.

Syn.-Mitrula vinosa, Berk., Flor. Tasm. ii, 273, I860; Cke., Mycogr. I04, f. I8I, I876 ; Sacc., Syll. viii, n. I18, I889.

Hab.- - On rotten wood and bark.

Distr.-Juan Fernandez (Bertero), Tasmania (Archer), New Zealand (Colenso, n. 407 b).

A portion of the type of $M$. Berterii, collected by Bertero in Juan Fernandez, was sent to Berkeley by Montagne, and is now in the Kew Herbarium; this has been examined, along with Berkeley's type of $M$. vinosa, and the two prove to be identical in every respect.

Mitrula Saccardoa, Bagnis, Micol. Romana, in R. Acad. del Lincei, ser. iii, I, 839, pl. I, f. 5, I887; Sacc., Syll. viii, n. Io6, I889.

Ascigerous portion globose-ovoid, stout, apical portion vinous purple, lower part white; stem stuffed, yellowish white. Asci linear-clavate; spores 8, hyaline, tinged vinous, guttulate, asperulate.

Hab.-On fallen and decayed stems and leaves.

Distr.-Italy (outside the gate of St. Pancrazio, Rome, Bagnis).

Apparently a very fine and distinct species, but rather imperfectly described. The somewhat coarse figure shows the entire fungus to be 7.5-8 cm. high; ascigerous portion elliptical, $2.5^{-3} \times 1 \mathrm{~cm}$.; stem $5 \mathrm{~cm}$. high, $3 \mathrm{~mm}$. thick at the apex, slightly tapering towards the base, inclined to be flexuous; spores obliquely I-seriate, $20-24 \times 7-9 \mu$.

Mitrula serpentina, Massee. (Pl. XIII, Fig. 68.)

Usually tufted, entire fungus dingy yellowish green or olive-green, stem usually paler, $2-4 \mathrm{~cm}$. high, sometimes much larger; ascigerous 


\section{Massee.-A Monograph of the Geoglosseae. 269}

portion about half the entire length of the fungus, clavate or subcylindrical, hollow, often compressed, terminating abruptly and irregularly below, glabrous, rather slimy when wet; stem thinner than the ascigerous portion, nearly cylindrical, minutely squamulose or granulose; flesh tinged green. Asci narrowly clavate, apex a little

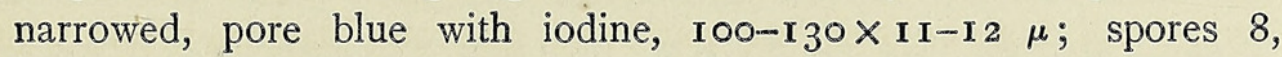
irregularly 2 -seriate above, $\mathbf{x}$-seriate below, hyaline, smooth, narrowly elliptical, ends rather acute, often slightly curved, 3-5-guttulate, then 3-septate, I3-18 $8 \times 5 \mu$; paraphyses slender, septate, straight, apex clavate and tinged green.

Syn.-Clavaria serpentina, O. F. Muell., Zool. Dan. Prod. 256, 1 776 ; Schrank, Baiersche Fl. ii, 57 I, I 789 .

Geoglossum viride, Pers., Comm. 40, 1797; Fries, Syst. Myc. i, 489, I 82 I ; Cke., Mycogr. 9, fig. I 4, I875 (spores too large); Phil., Brit. Disc. $3^{2}, 1887$.

Clavaria mitrata, $\beta$ viridis, Holmsk., Fung. Dan. 24, with fig., 1798.

Clavaria viridis, Schrad., Flor. Dan. tab. I258, f. I, r 79 r.

Leotia geoglossoides, Corda, Icon. Fung. iii, 37, fig. 94, 1839.

Leotia viridis, Fuckel, Symb. Myc. 284, 1869-70.

Mitrula viridis, Karst., Myc. Fenn. i, 29, I871 ; Massee, Brit. Fung.Fl. iv, 482, I 895 ; Sacc., Syll. viii, n. 1 24, I889.

Leptoglossum viride, Cke., Mycog. 25 o, 1879 .

Microglossum viride, Gillet, Disc. France, 25, with fig., I 879; Rehm, Kr.-Fl., n. 5866, I896.

Exs.-Rab., Fung. Eur. n. 524, 1625; Rehm, Ascom. I51; Phil., Elv. Brit. 54 ; Vize, Brit. Fung. 482 ; Libert, Crypt. Ard. Fasc. ii, n. I 23 ; Klotzsch, Herb. Myc. ed. Rab.n. 239; Fckl., Fung. Rhen. n. I 40 ; Cke., Fung. Brit. ed. ii, n. 395; Roum., Fung. Gall. Exs. n. 2378 ; Desm., Cr. France, sér. i, n. 425 ; Moug. and Nest., Stirp. Cr., n. 994 ; Kunze, Fung. Sel. n. 196 ; Karsten, Fung. Fenn. n. 449; Westend, Herb. Crypt. Belg. (Crepin), n. 863; Ellis and Everh., N. Amer. Fung. ed. ii, n. 2030 .

$H a b$.- On the ground among grass and moss, in damp places.

Disir.-Britain, Portugal, France, Belgium, Denmark, Sweden, Finland, Germany, Austria, Switzerland, Italy, United States (West Chester, Pa., Everhart), Sikkim (Sachoong, 8,000 ft., Yeumtong, I,200 ft., Dr. [now Sir] J. D. Hooker).

Variable to some extent in colour, depending on locality and season, ranging from yellowish green, through verdigris, to dark olive-green, 


\section{Massee.-A Monograph of the Geoglosseae.}

the stem is usually paler in colour than the ascigerous portion. The entire fungus generally becomes blackish green when dry. Usually rather densely clustered, the individual plants slender, $2-3 \mathrm{~cm}$. high, but sometimes much taller and stouter, as figured by Holmskiold.

Specimen from Persoon examined.

Mitrula olivacea, Sacc., Syll. viii, n. I25, I889; Massee, Brit. Fung.-Fl. iv, 483, 1895 .

Gregarious or caespitose, entire fungus $3-4 \mathrm{~cm}$. high, dry, dingy olive-green, sometimes with a purple sheen, stem paler, entirely blackish green when dry; ascigerous portion $\mathrm{I}-2 \mathrm{~cm}$. long, up to $5 \mathrm{~mm}$. broad, cylindric-ovate, apex usually narrowed, sometimes obovate or irregular in form, glabrous, more or less compressed and grooved; stem subcylindrical, glabrous, base slightly thickened and whitish. Asci narrowly clavate, apex narrowed, pore blue with iodine, 90-I00 $\times$ IO-II $\mu$; spores 8 , irregularly 2 -seriate above, I-seriate below, narrowly elliptical, ends rounded, 3-4-guttulate, hyaline, smooth, continuous, often slightly curved, I 5-19 9 5-6 $\mu$; paraphyses slender, tips slightly clavate and tinged olive.

Syn.-Geoglossum olivaceum, Pers., Obs. Myc. i, 40, tab. 5, f. 7 , I 796 ; Cooke, Mycogr. 9, fig. I4, I875.

Leptoglossum olivaceum, Cke., Mycogr. 250, 1879; Phil., Brit. Disc. $33, \mathbf{1} 887$.

Microglossum olivaceum, Gillet, Disc. France, 26, with a fig., 1879 ; Rehm, Kr.-Fl., n. 5868, 1896.

Geoglossum olivaceum, var. purpureum, Berk., Outl. pl. 22, f. 2, I 860.

Geoglossum carneum, Schultz, Flor. Starg. 486, 1806.

Exs.-Phil., Elv. Brit. n. 5 ; Cke., Fung. Brit. n. 650; Cke., Fung. Brit. ed. ii, n. 396 ; Jack, Leiner, u. Sitzenb., Krypt. Badens, n. 650; Rab., Fung. Eur. n. 1820; Kunze, Fung. Sel. n. 195.

$H a b$.- On the ground among short grass, moss, \&c.

Distr.-Britain, France, Germany, Belgium, Finland.

The $\beta$ purpureum of Berkeley differs only in colour, which is dingy purple when fresh, and becomes indistinguishable from the typical form when dry. The same is true of the form called Geoglossum carneum, Schultz, which is said to be slender, compressed, flesh-colour, stem paler. The colour of the type-form, even in the same patches, varies in different individuals to brown, olive, and purple. 


\section{Mitrula lutescens, Massee (non Berk.). (Pl. XIII, Fig. 77.)}

Scattered or fasciculate, entire fungus $3-7 \mathrm{~cm}$. high; ascigerous portion $\mathrm{I} 5-20 \mathrm{~mm}$. long, I-10 $\mathrm{mm}$. broad, at first subcylindrical, then compressed, lanceolate, apex rarely rounded, yellowish olive or greyish ochraceous, solid, flesh pale ochraceous, sharply differentiated from the stem, which is similar in colour except at the base, which is greenish both inside and out, minutely squamulose, especially upwards. Asci inoperculate, subclavate, slightly narrowed towards the base, I $30-$ I $50 \times \mathbf{I}^{-1} 7 \mu$; spores 8 , irregularly 2 -seriate, oblong-fusoid, straight or slightly curved, hyaline, 3-4-guttulate, 20-26 6 6-7 $\mu$; paraphyses slender, irregularly branched from the base, tips clavate or subcapitate, 3-4 $\mu$ thick, and often coated with mucilage.

Syn.-Microglossum lutescens, Boudier, Bull. Soc. Myc. France, I 4, pl. iv, f. I, I896.

Hab.-On sandy clay ground, sides of roads in woods.

Distr.-France (Montmorency, Boudier).

This species agrees in many respects with $M$. viridis, but I consider it quite distinct by the colour being more ochraceous than green except at the base of the stem, by the ascigerous portion being relatively shorter, more lanceolate, broader in the middle, and more compressed, also by the stem being finely squamulose; the spores are also a little larger and the asci a little smaller. It occurs on ground which is not pure clay. It is also neighbour to $M$. olivacea, but is well distinguished by its more ochraceous colour, general smaller size, stem longer than the ascigerous portion and greenish at the base, paraphyses usually not curved at the tips, and by the slightly larger and straighter spores. During drying, the present species becomes greener, whereas under the same conditions $M$. viridis becomes yellower (Boudier).

\section{Mitrula laricina, Massee. (Pl. XIII, Fig. 69.)}

Gregarious, entire fungus $2-6 \mathrm{~cm}$. high ; ascigerous portion variable in size and shape, clavate, subglobose, or ovate, sometimes more or less divided into two portions, often more or less compressed, especially when large, fragile, glabrous, becoming hollow, entirely adnate to the stem, but the lower margin sharp and distinct, usually slightly decurrent down opposite sides of the stem, varying in colour from egg-yellow to deep orange-red, $\frac{1}{2}-1 \frac{1}{2} \mathrm{~cm}$. high and broad; stem 2-5 $\mathrm{mm}$. thick, straight or wavy, smooth and with a silky sheen, 


\section{Massee.-A Monograph of the Geoglosseae.}

white, or with a tinge of pink or yellow, becoming hollow. Asci narrowly clavate, apex narrowed, the minute pore slightly blue with iodine, Io0-I $30 \times 8-9 \mu$; spores 8 , obliquely $\mathbf{I}$-seriate or often irregularly 2 -seriate near the apex, hyaline, smooth, elliptical ends blunt, usually slightly curved, often becoming distinctly I-septate at maturity, I 2-I $8 \times 3 \cdot 5^{-4} \mu$; paraphyses septate, sometimes branched, slightly thickened at the tip, about $2 \mu$ thick.

Syn.-Helvella laricina, Villars, Fl. Dauph. iii, 1045, tab. lvi (quoted lv in text), $\mathbf{1} 786-89$.

Clavaria phalloides, Bull., Champ. France, 214, pl. 465, f. 3, I 79 I -98 .

Clavaria epiphylla, Dickson, Plant. Crypt. iii, 22, tab. ix, f. Io, I 793 .

Leotia laricina, Pers., Syn. Fung. 6 I 4, I 80 I.

Leotia Ludwigii, Pers., Syn. Fung. 6I I, tab. 3, f. I3, I801.

Leotia Dicksoni, Pers., Syn. Fung. 6r 2, I801.

Leotia Bulliardi, Pers., Syn. Fung. 6r 2, 1801.

Mitrula paludosa, Fries, Syst. Myc. i, 49 I, I82 I ; Phil., Brit. Disc. 28, pl. ii, f. 6, I887; Cooke, Mycogr. Ior, fig. I 75, I 879 .

Mitrula phalloides, Chev., Fl. Paris, I I 4, I 826-27; Sacc., Syll. viii, n. 99, I889; Massee, Brit. Fung.-Fl. iv, 48I, figs. 29 and 30 on p. I 88 , I 895 ; Rehm, Kr.-Fl. n. 5860 , figs. I-4 on p. I I $43, \mathbf{1} 896$.

Leotia uliginosa, Grev., Scot. Crypt. Fl. tab. 312, I823.

Mitrula paludosa, var. pachyceps, Karst., Revis. Mon. Ascom. Finl. I I 0, I 885 .

Exs. - Roum., Fung. Gall. 3722 ; Flor. Exs. Austr.-Hung. n. I 975 ; Phil., Elv. Brit. n. 2 ; Rehm, Ascom. n. 601 ; Rabenh.-Winter, Fung. Eur. n. $2844 ; F c k l$., Fung. Rhen. n. I236; Klotzsch, Herb. Myc. ed. Rabenh. n. I32; Roum., Fung. Sel. Gall.n. I60; Zopf and Sydow, Myc. March. n. 3I, with fig.; Karst., Myc. Fenn. n. 24; Thümen, Myc. Univ. n. I I I ; Moug. and Nestler, Stirp. Crypt. n. 685; Desm., Crypt. France, sér. I, n. 606 ; Berk., Brit. Fungi, n. 278 ; Flor. Gall. and Germ. Exs. n. 796 ; Rav., Fung. Carol. Exs. n. $3^{6}$; Ellis, N. Amer. Fung. n. 433 .

Hab.-On decaying leaves and rotten wood in damp places, or when floating in water.

Distr.-Britain, France, Portugal, Italy, Germany, Sweden, Denmark, Belgium, Switzerland, Finland, Russia, United States.

When exceptionally large and having the pileus laterally compressed, 


\section{Massee.-A Monograph of the Geoglosseae. 273}

and with well-developed, decurrent lobes on opposite sides of the stem, the present species superficially resembles Spathularia clavata, from which species it is readily distinguished by the very different spores. Bulliard's specific name is antedated by that of Villars, as given above; the date given by Saccardo for Bulliard's work is that of the last-named author's Hist. des Pl. Vén. et suspectes de la France, and not the Hist. des Champ. which forms the second part of the Herb. de la France, dating I 79 I-98.

\section{Form alba.}

Entirely white, head subglobose; otherwise as in the typical form; spores often I-septate.

Syn.-Mitrula alba, W. G. Smith, Grev. i, I36, pl. Io, lower fig., I 872 ; Cooke, Mycogr. ıо2, f. I77, I875; Phil., Brit. Disc. 27, I887 ; Sacc., Syll. viii, n. Iо3, 1889 .

Mitrula phalloides, v. alba, Massee, Brit. Fung.-Fl. iv, 482, I895.

Hab.-Among damp or submerged dead leaves.

Distr.-England (East Budleigh, Perceval ; Carlisle, Dr. Carlyle), Italy (Bagnis).

Mitrula vitellina, Sacc., Misc. Mycol. ii. I 5, I885; Sacc., Syll. viii, n. I I 5 , I 889; Rehm, Kr.-Fl. n. 5865, I 896. (Pl. XII, Figs. 3-4a.)

Ascigerous portion subcylindrical, terete or somewhat compressed, apex narrowed, glabrous, bright egg-yellow, I-I $\cdot 5 \mathrm{~cm}$. long, $2 \cdot 5-3 \mathrm{~mm}$. thick; stem somewhat compressed, white, fibrillose, stuffed, $\mathbf{I} \cdot 5 \mathrm{~cm}$. long, 2.5-3 mm. thick, substance spongy-fleshy, white. Asci narrowly clavate, apex rounded or inclined to be truncate, not blue with iodine, $75^{-80} \times 7-8 \mu$; spores 8 , obliquely $\mathrm{I}$-seriate, or inclined to be 2 -seriate above, continuous, smooth, elliptical, often slightly inaequilateral, with a very slight yellow tinge, $7-8 \times 4 \mu$; paraphyses slender, septate, slightly thickened upwards, rare.

Syn.-Geoglossum (Microglossum) vitellinum, Bresadola, Revue Myc. iv, 21 2, I882 ; Bres., Fung. Tridentini, 4I, tab. xlv, f. I, I 88 I.

Hab.-Alpine pine woods.

Distr.-South Tirol (Valle di Rabbi, Bresadola).

Almost similar in habit and colour, except the stem, to Clavaria ligula, with which it has probably been confounded. Intermediate between Geoglossum and Mitrula (Bres.).

Specimens from Bresadola examined. 


\section{Massee.-A Monograph of the Geoglosseae.}

Mitrula elegans, Fries, Symb. Nov. I19, I851 ; Berk., Grev. iii, I 49, I 875 ; Hedw. I875, 9 ; Cooke, Mycogr. Io4, fig. I82, 1875; Sacc., Syll. n. I 19, I 889 。

Gregarious, entire fungus $4-7 \mathrm{~cm}$. high, dingy yellow when dry; ascigerous portion narrowly obovate, laterally compressed and slightly decurrent down opposite sides of the stem, glabrous, even, 4-7 $\mathrm{mm}$. high; stem elongated, slender, almost equal throughout, sometimes forked, glabrous, 3-4 mm. thick. Asci narrowly clavate, apex slightly narrowed, pore blue with iodine, $100 \times 8-9 \mu$; spores 8 , 2-seriate above, I-seriate near base of the ascus, smooth, continuous, linearfusiform, usually slightly curved, I $2-\mathrm{I} 4 \times 3 \mu$; paraphyses slender, septate, very slightly thickened at the tip.

Syn.-Leotia elegans, Berk., Lond. Journ. Bot. v, $6,1846$.

Hab.-On the ground.

Distr.-United States (Greene, n. 66), Ohio (Lindblom).

A striking species, remarkable for the long, slender stem, which at first sight suggests having been drawn up by growing amongst long grass or moss, but there are eight specimens in the Berkeley Herbarium at Kew, collected by Greene, and the same form was seen by Fries, hence it must be assumed to be normal. The stem is sometimes forked. The colour of the living fungus is not known; it was probably pale yellow. Type examined.

Mitrula luteola, Ellis, Amer. Nat. xvii, pt. i, I92, I883; Sacc., Syll. Suppl. x, n. 4466, I892. (Pl. XII, Figs. 23, 24 a.)

Entire fungus $\mathbf{I} \cdot 5^{-3} \mathrm{~cm}$. high ; ascigerous portion ovate or obovate, subplicate, usually laterally compressed, slightly decurrent down opposite sides of the stem, light yellow, $\frac{1}{2}-\frac{3}{4} \mathrm{~cm}$. wide; stem shorter than the fertile portion and paler in colour, distinctly tomentose throughout its length, often slightly hollow. Asci narrowly cylindricclavate, apex rounded or slightly truncate, not blue with iodine, about I $00 \times 6 \mu$; spores 8 , obliquely I-seriate, continuous, smooth, elliptical, often very slightly inaequilateral, with a very faint tinge of yellow in the mass, $6-7 \times 3 \mu$; paraphyses rare, stout, septate.

Exs.-Ellis, N. Amer. Fung. n. 978.

Hab.- On the ground among fallen pine leaves in sandy pine woods. Solitary or subcaespitose.

Distr.-United States (Newfield, N.Y., Ellis).

A very fine and distinct species, known by the tomentose stem, 
the narrow asci, and the small spores. The fungus becomes darker when dry, more especially the stem. Specimen from Ellis examined.

Mitrula rufa, Sacc., Syll, viii, n. I 23, I889. (Pl. XII, Figs. 28-30.)

Gregarious or scattered, entire fungus $3^{-6} \mathrm{~cm}$. high, dry, varying in colour from rufous or dusky brownish olive to dingy yellow, stem usually paler than the remainder ; ascigerous portion narrowly elliptical or clavate, often more or less laterally compressed and longitudinally rugulose, glabrous, $\mathrm{I}-2 \mathrm{~cm}$. long, $4-7 \mathrm{~mm}$. broad, not sharply differentiated from the thinner, minutely squamulose stem. Asci clavate, apex narrowed, pore blue with iodine, II $5^{-1} 40 \times$ IO-I $2 \mu$; spores 8 , irregularly 2 -seriate near the apex of the ascus, I-seriate below, hyaline, smooth, cylindric-fusoid, ends rather acute, usually slightly curved, $25-35 \times 5-6 \mu$, at first multiguttulate, finally 5 -septate; paraphyses slender, septate, tip slightly thickened and more or less curved.

Syn.-Geoglossum rufum, Schweinitz, Syn. Fung. Amer. Bor. n. I o I I, in Trans. Amer. Phil. Soc. iv, I81, 1834; Cooke, Mycogr. 205, fig. 346, I 875 .

Mitrula lutea, Mont., Ann. Sci. Nat. ser. 4, iii, 9 I, I 855 ; Cke., Mycogr. I03, fig. I79, I875; Sacc., Syll. viii, n. I 20, I889.

Geoglossum luteum, Peck, 24th Rep. N. Y. State Mus. 94, pl. 3, f. 20-24, I87 I ; Cke., Mycogr. 8, fig. 1 2, 1875 .

Geoglossum flavum, Cke., Bull. Buff. Soc. Nat. Sci. March, I875.

Leptoglossum luteum, Sacc., Syll. viii, n. I 58, I 889.

Mitrula lutescens, Berk. and Curt., Grev. iii, 149, 1875; Cke., Mycogr. I02, f. I78, I 875; Sacc., Syll. viii, n. I21, I 889.

Geoglossum pistillaris, Berk. and Cooke, Mycogr. 206, fig. 348, I 876 .

Mitrula pistillaris, Sacc., Syll. viii. n. I22, I 889 .

Exs.-Ellis, N. Amer. Fung. n. $5^{8 .}$

Hab.- On the ground among damp moss and grass, also in swamps among Sphagnum.

Distr.-United States (Louisiana, Dr. Hale, n. 4825; Lower Carolina, Ravenel, n. 2880; Newfield, N.Y., Ellis; Sandlake, N.Y., Peck; N. Jersey, specimen from Herb. Schweinitz), Guiana (Leprieur, n. (1075).

A well-marked fungus, slightly variable in colour, but very constant in all essential features. The amount of scaliness of the stem varies 


\section{Massee.-A Monograph of the Geoglosseae.}

to some extent, being in some specimens very evident, in others rudimentary, but always very slight. The fungus is normally dry, but, as in other species, may become slightly viscid in rainy weather. All Berkeley's types have been examined; a specimen of Geoglossum rufum, from Herb. Schweinitz; also specimens of the type of Mitrula lutea, collected by Leprieur in Guiana, and sent by Montagne to Berkeley.

Mitrula cucullata, Fries, Epicr. 584, 1836-38; Phil., Brit. Disc. 27, 1887; Sacc., Syll. viii, n. 100, 1889; Massee, Brit. Fung.-Flora, iv, 482, 1895; Cke., Mycogr. IоI, f. I76, I875; Rehm, Kr.-Fl. n. 5861, 1896. (Pl. XII, Figs. 39-4r.)

Gregarious; entire fungus $\mathbf{I}-2.5 \mathrm{~cm}$. high, dry; ascigerous portion variable in shape, ovate, obovate, or subglobose, usually somewhat laterally compressed, lower margin often free from the stem for a very short distance, hollow, glabrous, even, orange-yellow or orange-brown, $2-4 \times 2 \mathrm{~mm}$. ; stem very slender, usually crooked, glabrous, brown, base downy and darker in colour. Asci narrowly clavate, apex narrowed, pore blue with iodine, $60-70 \times 6 \mu$; spores 8 , irregularly 2 -seriate, hyaline, smooth, continuous, narrowly fusiform, straight or slightly curved, I 2-I $8 \times 3 \mu$; paraphyses slender, tips thickened.

Syn.-Elvella cucullata, Batsch, Elench. Fung. I89, fig. I32, I 786 .

Mitrula Heyderi, Pers., Tent. Disp. meth. Fung. 56 , pl. 3 , f. 12 , 1797 .

Leotia mitrula, Pers., Syn. Fung. 6r r, I80I ; Grev., Scot. Crypt. Fl. tab. 8I, I 823 .

Clavaria ferruginea, Sow., Eng. Fung. pl. 84, 1797.

Mitrula (Heyderia) Abietis, Fries, Syst. Myc. i, 492, I 82 I.

Geoglossum cucullatum, Fries, Elench. Fung. i, 233, 1828.

Verpa ferruginea, Wallr., Flor. Germ. Crypt. ii, 549, 1833.

Exs.-Rab., Fung. Eur. n. 37, 669, I 223 , I315, I345; Roum., Fung. Gall. Exs. n. 7 I 3,2377 ; Phil., Elv. Brit. n. 53; Krieger, Fung. Sax. 922 ; Sydowe, Myc. March. n. 1261 ; Cke., Fung. Brit. n. 232; Fuckel, Fung. Rhen. n. I237 ; Schweiz. Krypt. n. 43 I ; Desm., Cr. France, sér. I, n. I I55; Karsten, Fung. Fenn. n. 447 ; Berk., Brit. Fung. n. 254 ; Thïm., Fung. Austr. n. I014; Holl, Schmidt, and Kunze, Deutschl. Schwämme, n. xcviii.

$H a b$. - On fallen leaves of various conifers, \&c.

Distr.-Britain, Portugal, Sweden, France, Germany, Denmark, 
Italy, Russia, United States (Forestburgh, N.Y., Peck, n. 320), Tasmania (Rodway; on small twigs of Eucalyptus).

The spores are distinctly $\mathbf{I}$-septate in a specimen named by Persoon, and also in British specimens collected at Carlisle by Dr. Carlyle.

Phil., Elv. Brit. n. 2, and Ellis, N. Amer. Fung. n. 433, quoted by Rehm (Kr.-Fl. n. 586I) under the present species, belong, in both instances, to Mitrula laricina. Mitrula pusilla, Fr., growing on fallen leaves of Pinus silvestris, differs from the present in its slightly smaller asci and spores, and is perhaps only a small form of $M$. cucullata. Mitrula sphaerocephala, Bres., also occurring on larch leaves, differs from $M$. cucullata in its much thicker spores.

Mitrula pusilla, Fries, Syst. Myc. i, 493, I82 I ; Sacc., Syll. viii, n. IоI, I889; Rehm, Kr.-Fl. n. 5862, I896; Boudier, Bull. Soc. Myc. France, ix, ro, pl. 2, f. 4, I893. (Pl. XII, Figs. 47-49.)

Gregarious; entire fungus 4-7 $\mathrm{mm}$. high; ascigerous portion clavate or subglobose, glabrous, rusty yellow, $\cdot 5-\mathbf{I} \cdot 5 \mathrm{~mm}$. high, with a slight indication of a lower free margin encircling the stem, which is filiform, usually crooked, yellow, brownish and downy at the base. Asci narrowly clavate, pore blue with iodine, $45^{-} 5^{6 \times 6 \mu}$; spores 8 , I-seriate, or inclined to be 2 -seriate above, hyaline, smooth, continuous, fusiform, ends acute, often slightly bent, I $2-\mathbf{I} 5 \times$ $2.5 \mu$; paraphyses filiform, tips slightly thickened.

Syn.-Leotia mitrula, $\gamma$ pusilla, Alb. and Schwz., Consp. Fung. Nisk., 293, 1805 .

Leotia pusilla, Nees, Syst. Myc. I73, pl. I7, f. I60, I81 7.

Mitrula fusispora, Preuss, Plant. Hoyersw. n. I57 ; Sacc., Syll. viii, n. I02, I889.

Exs.-Krieger, Fung. Sax. n. 923.

Hab.-On fallen leaves of Pinus silvestris.

Distr.-Germany, France.

A minute species, superficially resembling Mitrula cucullata; for distinction see note under the last-named species.

Mitrula sphaerocephala, Bres., Fung. Trid. 66, tab. lxxxi, f. 2, r88I ; Sacc., Syll. viii, n. 107, I889.

Ascigerous portion waxy-fleshy, I mm. diameter, lurid ochraceous, glabrous, at length pale primrose with the spores; stem stuffed, expanding into the capitulum, to which it is similar in colour, as is 


\section{Massee.-A Monograph of the Geoglosseae.}

also the flesh, base brown, 4-5 $\mathrm{mm}$. long by $\frac{2}{3} \mathrm{~mm}$. thick. Asci cylindric-clavate, the minute pore blue with iodine, $130-150 \times 8-12 \mu$; spores subcylindrical, ends rounded, tinged yellow, minutely granular, 2-seriate, I 5-I $8 \times 6-7 \mu$; paraphyses clavate at the tips, septate, 3-4 $\mu$ thick, containing ochraceous granules.

Hab.-On fallen larch leaves.

Disir.-N. Italy.

A near ally of Mitrula cucullata, Fr., the spherical headed form of which it closely resembles superficially, but is clearly distinct in the very different form and size of the spores. Bresadola states that as far as he has seen, the ascigerous portion is constantly globose. Not examined.

Mitrula gracilis, Karsten, Revis. Mon. I10, 1885; Sacc., Syll. viii, n. 105, I 889 .

Entire fungus $2-2.5 \mathrm{~cm}$. high ; ascigerous portion variable in shape, generally oblong or ovoid, obtuse, fragile, glabrous, orange-brown when dry, I-2 mm. long; stem filiform, equal, flexuous, deep fleshcolour, $2 \mathrm{~cm}$. high. Asci sublanceolate, $60-85 \times 5-6 \mu$; spores somewhat 2 -seriate, fusoid, straight, 8-I $2 \times 2 \mu$; paraphyses filiform.

Hab.-Among dead Hypnum.

Distr.-Finland (Knjäscha, on the White Sea, Karsten).

Karsten considers the present species as occupying a position intermediate between Mitrula elegans, Berk., and $M$. phalloides, Chev. (= Mitrula laricina, Mass., of this work).

Mitrula sclerotipes, Boud., Bull. Soc. Bot. France, xxiv, 309, pl. iv, f. 5,1877 (the specific name was written 'sclerotipus' by the author); Cke., Mycogr. 220, f. 370, 1879; Sacc., Syll. viii, n. 108, I889.

Entire fungus rusty yellow, $\mathbf{I} \cdot 5^{-2} \mathrm{~cm}$. high, springing from an irregularly elliptical, yellowish sclerotium 8-10 mm. long; ascigerous portion clavate, more or less wrinkled, sharply differentiated from the stem, solid, glabrous, $4-7 \mathrm{~mm}$. high, about $3 \mathrm{~mm}$. thick; stem solid, even, glabrous, slender, sometimes dividing into $2-3$ branches, each bearing an ascigerous portion at its apex, whitish and slightly thickened at the point where it springs from the sclerotium. Asci narrowly clavate, apex narrowed, pore blue with iodine, $5 \circ \times 4-5 \mu$; spores 8 , irregularly 2 -seriate above, I-seriate below, hyaline, con- 
tinuous, smooth, narrowly elliptic-fusiform, straight or slightly curved, 7-10 $\times 2 \mu$; paraphyses slender, very slightly thickened upwards.

Hab.-On the ground in damp places among moss and dead leaves.

Distr.-France (Montmorency, Boudier).

A very distinct species, remarkable for springing from a sclerotium, and also for having the base of the ascigerous portion distinct from the stem for a very short distance, and thus forming a very slight free margin. Specimen from Boudier examined.

Mitrula muscicola, Henning, Öfvers. af K. Vet.-Akad. Förh., I 885, 7 I, tab. viii, f. 6-8; Sacc., Syll. viii, n. I04, I889. (Pl. XIII, Fig. 73.)

Gregarious ; ascigerous portion subglobose-ovoid, rugulose towards the base, ferruginous, stuffed, 8-I $5 \mathrm{~mm}$. high ; stem yellow, flexuous, obsoletely fistulose, $5^{-12} \mathrm{~mm}$. high, $0.5 \mathrm{~mm}$. thick. Asci cylindrical or clavate, $5 \mu$ thick near the apex ; spores $4-6$ in an ascus, hyaline, continuous, lanceolate, 9-Io $\times 2-3 \mu$; paraphyses filiform, $\mathbf{I} \cdot 3 \mu$ thick.

Hab.-On Paludella squarrosa, Ehrh., and Racomitrium fasciculare, Brid.

Distr. - Norway (Hummelfjeld, I 270 metres alt., Henning).

Mitrula Rehmii, Bresad., resembles the present species in many points, but is somewhat larger.

Mitrula Rehmii, Bresad., Fung. Trident. ii, 4 I, tab. cxlvii, f. 2, I892; Rehm, Kr.-Fl. n. 5864, figs. 2-3, p. I I 43 (after Bresadola); Sacc., Syll. xi, n. 2405 , 1895 .

Gregarious, entire fungus $2-3.5 \mathrm{~cm}$. high; ascigerous portion obovate, rarely subglobose, stuffed, surface rugose, with thick longitudinal ribs, tawny flesh-colour, $3 \cdot 5-4 \cdot 5 \mathrm{~mm}$. high, by about $3 \mathrm{~mm}$. broad; stem stuffed, equal, pruinose then glabrous, white then yellow, 2-3 cm. long, I mm. thick; flesh yellow, inodorous. Asci clavate-fusoid, apex narrowed, the minute pore blue with iodine, 70-80 $\times 6-8 \mu$; spores narrowly elliptical, hyaline, smooth, usually slightly curved, at length I-septate; paraphyses filiform, branched, containing ochraceous granules, tips slightly thickened, about $2 \mu$ thick.

Hab.-On moss, Hypnum Schreberi, in pine woods.

Distr.-South Tyrol (Valle di Sole, Bresadola). 


\section{Massee.-A Monograph of the Geoglosseae.}

Bresadola says that this species is parasitic on the moss. Allied to Mitrula muscicola, Henning, differing mainly in the somewhat longer stem and more uneven hymenium.

Mitrula bicolor, Pat., Journ. de Bot. vii, 344, 1893 ; Sacc., Syll. Suppl. xi, n. 2404, I895.

Solitary, erect, $6 \mathrm{~cm}$. high, quite glabrous; ascigerous portion elongate-lanceolate, $2 \mathrm{~cm}$. long, $4 \mathrm{~mm}$. broad, compressed, here and there plicate, the attenuated apex obtuse, lower part narrowed into the stem, brown; stem subterate, channelled, $2 \mathrm{~mm}$. thick, flexuous, rigid, pellucid, fuscous. Asci subclavate, apex narrowed, I IO-I $20 \times$ I 2-I $5 \mu$; spores 8 , oblong, ends obtuse, straight or slightly curved, hyaline, continuous, with I-2 large oil-globules, IO-I $2 \times 6 \mu$; paraphyses filiform, tips slightly thickened.

Hab.- (?)

Distr.-Thibet (province of Su-tchuen, Farges).

This species is the size of Mitrula rufa; the ascigerous portion and summit of the stem are reddish brown with a green tinge (Patouillard).

\section{Mitrula multiformis, Massee.}

Gregarious; ascigerous portion fuscous-brown, glabrous, even or rugulose, distinct from the stem, usually clavate, compressed, hollow ; rarely capitate, subrotund, hollow; or pileate, campanulate, undersurface sterile, plane, whitish, stuffed; stem whitish, even, equal -or slightly thickened downwards, fistulose, $\mathbf{I} \cdot 5 \mathrm{~mm}$. thick. Asci cylindricclavate; spores 8, continuous, hyaline, fusoid, rarely subglobose; paraphyses filiform, septate (?).

Form clavata. (Pl. XIII, Fig. 58.)

Ascigerous portion $5^{-18} \mathrm{~mm}$. high, 3-6 mm. broad; stem $\mathrm{r}-2 \mathrm{~cm}$. high. Asci $6-8 \mu$ thick near the apex, $3-4 \mu$ thick at the base; spores $9-\mathrm{I} 3 \times 3.5-4 \mu$; paraphyses $\mathrm{I} \cdot 5 \mu$ thick.

Form capitata. (Pl. XIII, Fig. 59.)

About $\mathbf{I} \mathrm{cm}$. high; asci $7 \mu$ thick near the apex, base $3 \mu$ thick, or cylindrical and $5 \mu$ thick. Spores II-I $2 \times 3-4 \mu$; paraphyses I. $5 \mu$ thick.

Form pileata. (Pl. XIII, Fig. 60.)

About $\mathrm{x} \mathrm{cm}$. high; apex of ascus $6-7 \mu$ broad, base $2 \cdot 5-4 \mu$; 


\section{Massee.-A Monograph of the Geoglosseae. 28I}

spores $7-9$ and $2 \cdot 5-3 \cdot 5 \mu$, or subglobose and $3-5 \mu$ diameter; paraphyses $\mathbf{I} \cdot 3 \mu$ thick.

Syn.-Geoglossum multiforme, Henn., Öfvers. af K. Vet.-Akad. Förh., I 885, 70, tab. viii, f. 1-5.

Microglossum multiforme, Sacc., Syll. viii, n. I29, I889.

Hab.-In swampy places. Forms capitata and clavata on Hypnum fluitans, L., form pileata on fallen twigs and leaves of Betula.

Distr. - Norway (Hummelfjeld, Henning).

Mitrula globosa, Sommerf., Suppl. Flor. Lapp. 287 , pl. iii, I826; Fries, Elench. i, 224, I828; Sacc., Syll. viii, n. 109, I889. (Pl. XIII, Fig. 54.)

Scattered; entire fungus $3-5 \mathrm{~cm}$. high, every part dark bay; ascigerous portion globose, even, solid, about $5 \mathrm{~mm}$. diameter, not decurrent down the stem, which is about $2 \mathrm{~mm}$. thick, narrowed towards the base, slightly crooked, solid, glabrous.

Hab.-Sandy ground.

Distr.-Lapland (Saltdalen, Nordland, Sommerfelt).

The present species, although imperfectly described, appears to be a very marked fungus, and should be found again. Sommerfelt states that he observed it for several years in the same locality, in October. Sommerfelt's figure is reproduced.

Mitrula sclerotiorum, Rostr., Mykol. Meddel. I888, p. Io; Sacc., Syll. viii, n. I I3, I889.

Ascigerous portion globose-ellipsoid, pallid, margin adnate to the stem, which is $5^{-8} \mathrm{~mm}$. long, $\frac{1}{2}-\mathbf{I} \mathrm{mm}$. thick. Asci cylindrical, pedicel elongated, $35^{-60} \times 4-5 \mu$; spores fusoid, $7-8 \times \mathbf{I}-2 \mu$.

Hab.-Springing from a sclerotium on the fallen stems of Lotus and Medicago.

Distr.-Germany (Constanz, Rostrup).

May possibly prove to belong to some genus belonging to the Pezizeae.

Mitrula microspora, Massee, Brit. Fung.-Fl. iv, 483, I895. (Pl. XIII, Figs. 55-57.)

Entire fungus 3-6 cm. high, black; ascigerous portion narrowly clavate, obtuse, sometimes irregular in form and more or less laterally compressed, glabrous, differentiated from the stem and a little shorter, $\mathbf{I} \cdot 5^{-2} \mathrm{~cm}$. long, 4-7 $\mathrm{mm}$. broad, more or less viscid when moist; 


\section{Massee.-A Monograph of the Geoglosseae.}

stem cylindrical, mostly equal throughout, minutely squamulose under a lens, or in some instances almost glabrous. Asci narrowly clavate, apex narrowed, pore blue with iodine, II 5-I30XI2 $\mu$; spores irregularly $\mathbf{2}$-seriate above, $\mathbf{I}$-seriate below, hyaline, smooth, narrowly cylindrical, ends slightly narrowed, multiguttulate, then becoming 3-5-7-septate, usually slightly curved, $28-40 \times 5 \mu$; paraphyses numerous, cylindrical, septate, not at all or very slightly thickened at the tips, which are agglutinated together.

Syn.-Geoglossum microsporum, Cke. and Peck, $25^{\text {th }}$ Rep. N.Y. State Mus. 97, I872; Cke., Mycogr. I, f. I I, I875 (spore-measurement wrong); Phil., Brit. Disc. 39, I887 (spore-measurement wrong).

Leptoglossum microsporum, Sacc., Syll. viii, n. I57, I889.

Exs.-Desm., Crypt. France, sér. I, n. 42 I (called Geoglossum glabrum, Pers.).

Hab.-On the ground, under ferns, \&c.

Distr.-Britain, France (Desm., Crypt. France, n. 42 I, called Geoglossum glabrum, P.), United States (Greig, N.Y., Peck, n. I I 5).

The above diagnosis is drawn up from the type specimen sent from the United States by Peck, and on which the species is founded. In the original description in the $25^{\text {th }}$ Rep. N. Y. State Mus. p. 97, the spore measurements are $.0007^{\prime}-0013^{\prime}$ long.

Some time afterwards Cooke again published the same species in Mycographia 8, f. I.I, as Geoglossum microsporum, C. and P., adding, 'Figured from specimens communicated by C. H. Peck.' I have examined every specimen sent to Cooke by Peck from America, but find nothing agreeing with Cooke's measurements, which I imagine to represent an uncorrected mistake, as the figures of the spores given by Cooke do not justify the statement. Phillips, in Brit. Disc., p. 39, has unfortunately given Cooke's incorrect diagnosis from Mycographia instead of the approximately correct one from the $25^{\text {th }}$ Report. It is evident that Phillips had not examined the specimens; finally, if Mr. C. Bucknall's specimen found at Hanham, Clifton, has spores ro $\mu$ thick, it is not G. microsporum, but a new species which would naturally be called Mitrula microspora, Massee.

Var. tremellosa, Mass., Brit. Fung.-Fl. iv, 484, 1895 .

Somewhat tremelloid when living; ascigerous portion subcompressed, hollow, stem smooth, in other respects conforming with the typical form. 
Massee.-A Monograph of the Geoglosseae. 283

Syn.-Geoglossum microsporum, C. and P., var. tremellosum, Cke., Grev. iv, ro9, 1876.

Geoglossum tremellosum, Cke., Mycogr. 206, f. 347, 1879; Phil., Brit. Disc. 39, I 887 .

Lepioglossum tremellosum, Cke., Syll. viii, n. I56, $\mathbf{1} 889$.

Hab.- - On the ground.

Distr.-Scotland (Rannoch, Dr. Buchanan White).

As shown by the synonymy, this was first considered as a variety of $M$. microspora, and afterwards raised to specific rank. I prefer the varietal position, and indeed have doubts as to whether it is more than a mere form.

\section{Var. littorale.}

Scattered or caespitose, $0.5^{-I} \cdot 5 \mathrm{~cm}$. broad, black; ascigerous portion clavate, unequal, compressed and wrinkled, brittle, viscid. Asci fusiform, I00-1 $20 \times \mathbf{I} 6-18 \mu$; spores cylindrical, hyaline, $\mathbf{I}-5$, usually 2 -septate, $50-60 \times 5 \mu$; paraphyses septate, brown, constricted.

Syn.-Leptoglossum littorale, Rostrup, Bot. Tidssk. xviii, 76, 1892 ; Sacc., Syll. Suppl. xi, 2408, I 895 .

Hab.-Sandy ground.

Disir.-Denmark (Rostrup).

Unknown to me. Judging from the diagnosis, this species will possibly prove to be only a form of $M$. microspora.

Mitrula arenaria, Massee.

Scattered or caespitose, $2-4 \mathrm{~cm}$. high, $0.5^{-2} \mathrm{~cm}$. thick, black; ascigerous portion irregularly clavate, compressed, even ; stem squamulose, tinged olive. Asci fusiform, narrowed below into a long pedicel, I $00 \times 12-13 \mu$; spores elongato-cylindrical, hyaline, continuous, often with several oil-globules, $25-30 \times 4-6 \mu$; paraphyses brown, septate, tips slightly clavate, crooked.

Syn.-Microglossum arenarium, Rostrup, Bot. Tidssk. xviii, 76, I 892 ; Sacc., Syll. Suppl. xi, n. 2406, I895.

Hab.--Sandy ground.

Distr.-Denmark (Rostrup).

Unknown to me. Appears to differ from $M$. microspora in the continuous spores and the olive stem.

Mitrula partita, Massee.

Glabrous, black, coriaceous, gelatinous ; ascigerous portion tongue- 


\section{Massee. - A Monograph of the Geoglosseae.}

shaped, usually split down its entire length, and sometimes each portion is again incised to a greater or less depth, hymenium covering every part, $\mathrm{I} 5 \mathrm{~mm}$. long by $6-8 \mathrm{~mm}$. broad; stem glabrous, slender, 2-5 cm. long, $3 \mathrm{~mm}$. broad. Asci elongated, obtuse, becoming blue with iodine round the pore, $130 \times 10 \mu$; spores 8 , somewhat 2-seriate, hyaline, continuous, straight, curved, or undulate, elongatefusoid, $20-30 \times 3-6 \mu$; paraphyses linear, hyaline; the tips of the paraphyses and asci encrusted with a brown substance.

Syn.-Microglossum partitum, Pat., Rev. Mycol., I890, I35, pl. cvii bis, fig. 2 ; Sacc., Syll. Suppl. x, n. 4467, I892.

Hab.-On the ground.

Distr.-China (Tsang-chan, above Ta-li ; M. l'abbé Delavay).

Patouillard considers the present species as allied to Microglossum Hookeri (= Mitrula purpurascens of this work); but quite distinct in the divided fertile portion, and the shape of the paraphyses.

\section{Doubtful species.}

Mitrula (?) antarctica, Speg., Fung. Patag. n. 58, in Bol. Acad. Nacional de Cien. de Córdoba, xi, 54, I887 ; Sacc., Syll. viii, n. 126, I889.

Solitary or in groups of $2-3$ individuals, entire fungus $4-7 \mathrm{~cm}$. high, quite even and glabrous; ascigerous portion round when young, then laterally compressed, spathulate-clavate, $2-3 \mathrm{~cm}$. long by $6 \mathrm{~mm}$. broad, fistulose, rugulose and plicate in places, white then honey-colour, often waxy looking and pellucid, apex obtuse, rounded, base attenuated and abruptly and irregularly constricted where it joins the stem, which is round, elongated, gradually and slightly thickened upwards, base elongated, attenuated, often contorted, brownish-rufous or brownish flesh-colour.

Hab.-Among rotten fallen leaves in woods.

Distr.-Patagonia (Voces Bay, Spegazzini), Fuegia (Ushuvaia, Spegazzini).

The above is Spegazzini's description, who states that it was drawn up from living specimens, which were afterwards lost; hence the fructification is unknown.

Mitrula alba, Massee.

Entire fungus about $2.5 \mathrm{~cm}$. high, fasciculate or solitary; ascigerous 
Massee.-A Monograph of the Geoglosseae. 285

portion cylindrical, even, white, confluent with the stem, which is abruptly black, passing into greenish white; spores $\frac{3}{80}$ of an inch.

Syn.-Geoglossum album, Johnson, Minnes. Myc. n. 630, I878.

Mitrula Johnsoni, Sacc., Syll. viii, n. I 6 , I889.

$H a b .-$ On the ground and on fallen wood in woods.

Distr._United States (Minnesota, Johnson).

Apparently a distinct species, but imperfectly described. Spores measuring $\frac{3}{80}$ of an inch is evidently a slip; but what was intended? Saccardo suggests $\frac{3}{8000}(=9-\mathrm{IO} \mu)$, but this is not certain. Saccardo's name was created on account of a previous Mitrula alba, W. G. Smith; the latter, however, being simply a white form of Mitrula phalloides, Chev., Johnson's original specific name has been restored.

Mitrula exigua, Fries, Elench. i, 235, I822; Sacc., Syll. viii, n. I I0, I889.

Minute, simple, scattered; pileus mitriform, shining white; stem semipellucid, base black.

Syn.-Leotia exigua, Schwz., Syn. Fung. Car. Sup. n. I I I 9, in Soc. Nat. Cur. Lips. I822, p. 87 .

Hab. - Not uncommon on fallen stems. Pileus 4-5 mm. high, inflated, white; stem $2 \mathrm{~mm}$. high (Schwz.).

Distr.-United States (N. Carolina, Schweinitz).

\section{LeOtia, Hill.}

More or less gelatinous; ascigerous portion pileate, rather fleshy, imperfectly hollow, margin thick and incurved towards the stem, upper surface fertile, under surface sterile; stem erect, central. Asci narrowly clavate, apex more or less narrowed, pore not blue with iodine; spores hyaline, narrowly elliptical, becoming transversely septate, 2-seriate in the ascus ; paraphyses present.

Leotia, Hill, Hist. Pl. 43, I 75 I.

Helvella, Linn., Sp. Plant. ed. iii, I649, I 764 , in part.

Helotium, Fries, Summa Veg. Scand. $354, \mathbf{1} 846$, in part.

Cudonia, Fries, Summa Veg. Scand. $348, \mathbf{1} 846$, in part.

Cudoniella, Sacc., Consp. Gen. Disc., in Bot. Central. xxxviii, I884, in part. 


\section{Massee.-A Monograph of the Geoglosseae.}

Elvella, Clavaria, Tremella, Peziza, Phallus, in part, of old authors. The present genus resembles Vibrissea in the somewhat fleshy pileus having the free, thick margin incurved towards the stem, but differs materially in the much shorter, narrowly elliptical spores which are arranged in a 2 -seriate manner in the ascus. Saccardo has placed the present genus in the Bulgarieae on account of its subgelatinous consistency, but I consider its true affinity is with the present group. Leotia approaches very closely to Helotium; the latter differs in the firmer texture, and in the more or less distinctly parenchymatous cortex and excipulum. This line of demarcation places Leotia acicularis, Pers., in Helotium.

Distr.-Of the five well-defined species, four are confined to Europe, and all are rare. The fifth, L. lubrica, has a wide range-Europe, Sikkim (8-9000 ft.), Tasmania, New Zealand, Victoria, and United States. The doubtful species, if verified, extend the range of the genus to Greenland on the one hand, and South Africa on the other.

\section{Key to THE SPECIES.}

\section{Pileus more or less tinged green.}

atrovirens. Plant $1-2 \mathrm{~cm}$. high, entirely dark green; stem minutely squamulose.

lubrica. Plant $4-8 \mathrm{~cm}$. high; pileus yellowish-green to dark green; stem not squamulose.

\section{Pileus not green.}

marcida. Plant 4-10 $\mathrm{cm}$. high, every part dingy yellow; stem long, slender, wavy.

aquatica. Plant I-2 $\mathrm{cm}$. high, entirely whitish; pileus becoming brownish.

stagnalis. Plant $\mathrm{I}-2 \mathrm{~cm}$. high; pileus yellowish flesh-colour.

Leotia atrovirens, Pers., Myc. Eur. 202, tab. ix, f. I-3, I823; Fries, Syst. Myc. ii, 30, 1823; Sacc., Syll. viii, n. 2512, 1889; Quélet, Enchirid. 267 , 1886; Rehm, Kr.-Fl. n. 588ı, I896; Cke., Mycogr. 219, f. 368,1879 (scales on stem too large). (Pl. XIII, Figs. 8I, 82.) 
Gregarious, or often in clusters of $2-4$ plants, entire fungus $\mathrm{I}-2 \mathrm{~cm}$. high; ascigerous portion fleshy, undulate or almost plane, margin thick, incurved, glabrous, blackish-green, 4-8 $\mathrm{mm}$. broad; stem I-I. $5 \mathrm{~cm}$. long, about $3 \mathrm{~mm}$. thick, more or less distinctly squamulose, equal or thickened upwards, coloured like the fertile portion, or paler; flesh pale greenish-yellow. Asci clavate, apex narrowed, pore not blue with iodine, $\mathbf{I} 30-\mathbf{I} 50 \times$ I I-I $2 \mu$; spores 8 , irregularly 2 -seriate above, I-seriate below, hyaline, smooth, narrowly elliptical, ends obtuse, usually straight, $18-22 \times 5-6 \mu, 3-5$-guttulate; paraphyses slender, septate, often branched, tips scarcely thickened, greenish.

Syn.-Helotium atrovirens, Sprengel, Syst. iv, 489, I 827 .

Exs.-Rab., Fung. Eur. n. $5^{22}$ (poor specimens).

$H a b .-O n$ the ground in woods, in damp places.

Distr.-Germany, France (Montmorency, Boudier).

Requires to be carefully distinguished from dwarf forms of Leotia lubrica, Pers. The chief distinctions are, the absence of the piriform tips of the paraphyses, so characteristic of all forms of $L$. lubrica; the somewhat smaller asci, and the more distinctly squamulose stem.

There is a specimen in the Kew Herbarium labelled 'Leotia atrovirens, W. G. Farlow, Mass., U.S.A., n. 4.' This specimen is in reality $L$. lubrica, f. chlorocephala, as defined in the present work; therefore if the evidence of $L$. atrovirens occurring in the United States happens to depend on this specimen, it should be cancelled.

Leotia lubrica, Pers., Comm. Fung. Clav. 3 I, I 797 ; Pers., Syn. Fung. 6r 3, I801 ; Fries, Syst. Myc. ii, 29, r823; Wallr., Flor. Crypt. Germ. iv, 55I, n. 2788, also vars. lacunosa, umbonata, laevis, revoluta, on same page, 1833; Berk., Outl. pl. 22, f. I, I860; Cke., Mycogr. 97, fig. I 7 1, 1875; Phil., Brit. Disc. 22, 1887; Massee, Brit. Fung.Fl. iv, 47I, I895; Sacc., Syll. viii, n. 2510, r889. (Pl. XIII, Figs. 6I-64.)

Gregarious, or in small clusters, somewhat gelatinous, entire fungus 3-9 $\mathrm{cm}$. long; ascigerous portion irregularly hemispherical, inflated, sometimes depressed above, at others more or less umbonate, wavy, margin obtuse, incurved, glutinous, glabrous, varying from dingy yellow with a tinge of green, dingy ochraceous green, to lurid verdigris-green, I-2 cm. across; stem 3-8 cm. high, 4-8 $\mu$ thick, nearly equal, or more or less inflated at the base, pulpy within then hollow, externally yellowish, or tinged green, with very minute, white 
innate granules. Asci clavate, apex slightly narrowed, pore not blue with iodine, $150-200 \times 10-12 \mu$; spores 8 , irregularly 2 -seriate above, I-seriate near the base of the ascus, hyaline, smooth, narrowly elliptical, ends rather pointed, straight or slightly curved, 3-6-guttulate,

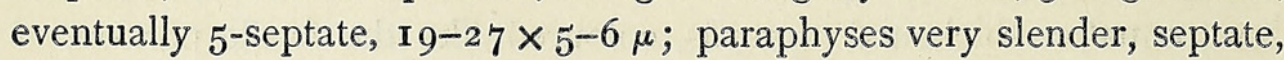
frequently branched, tips piriform and greenish.

Syn.-Fungus gelatinosus flavus, Vaill. Paris, 201, tab. ii, f. 7-9, I 727 ; Müll., Flor. Dan. tab. 719, I797.

Leotia gelatinosa capitulo subviridi, Hill, Hist. Pl. 43, I 75 I.

Elvella lubrica, Scop., Plant. Carn. ii, 477, 1772.

Helvella lutea, Berg., Phyt. i, tab. I 5 I, I 783-84.

Peziza cornucopiae, Hoffm., Veg. Crypt. Germ. ii, 26, tab. 6, f. I, I 790 .

Helvella gelatinosa, Bull., Champ. France, 296, tab. 473, f. 2, I 79I ; Rehm, Kr.-Fl. n. 5880, f. I-4, p. I I6 I, I896.

Leotia lubrica, Pers., Comm. Fung. Clav. 31, I797; Pers., Syn. Fung. 6r3, I80I.

Clavaria tremula, Holmsk., Fung. Dan., 27, with an excellent fig., I 799.

Merulius lubricus, Schum., Pl. Saell. ii, 368, 1803.

Hygromitra tremula, Nees, Syst. fig. I 44, I8 I 7 .

Helvella favo-virens, Nees, Syst. fig. I62, I81 7 .

Exs.-Cooke, Fung. Brit. n. 231 ; Roum., Fung. Gall. n. 712 ; Rabenh., Fung. Eur. n. 714, 2405, 2509; Phil., Elv. Brit. n. I36; Rehm, Ascom. n. Iог; Fuckel, Fung. Rhen. n. II 38 ; Sydow, Myc. March. nn. 278, 667 ; Klotzsch-Rabenh., Herb. Myc. 29; Vize, Brit. Fung. n. 480; Oudemans, Fung. Neerl. n. 286; Karsten, Fung. Fenn. n. $46 \mathrm{I}$; Thïmen, Fung. Austr. n. $5 \mathrm{I} 7$; Ellis, N. Amer. Fung. n. 57 ; Thümen, Myc. Univ. n. II I2;Berk., Brit. Fung. n. 255 ; Desmazières, Crypt. France, sér. i, n. 426; Westendorp, Crypt. Belg. n. 763; Mougeot and Nestler, Stirp. Crypt. n. 583; Holl, Schmidt, and Kunze, Deutschl. Schw. n. ccxxiv.

Hab.-On damp ground in woods and shady places, also in swamps, peat-bogs, \&c.

Distr.-Britain, Ireland, Spain, Portugal, France, Switzerland, Belgium, Germany, Sweden, Italy, Finland, Sikkim (Sinchul, 8,600 ft., Dr. [now Sir] J. D. Hooker, n. I3 I), Tasmania (Archer), New Zealand (Colenso), Victoria (Müeller), United States (Salem, Schweinitz; North and South Carolina, Curtis, nn. 508, 2400). 


\section{Massee.-A Monograph of the Geoglosseae. 289}

A very variable species, both in form and colour, depending upon the amount of moisture and shade to which it is exposed during development. In some cases a dingy ochraceous yellow, with only a tinge of green, is the predominating colour, in other examples the lurid green colour predominates throughout. The commonest European form has the ascigerous portion dingy olive-green, and the stem yellow, with minute, innate squamules or granules. The slimy cap is sometimes almost even, at others much waved, especially at the margin, imperfectly hollow, and either inflated or finally collapsed, sometimes brownish-red. Stem sometimes short and narrowed towards the base, at others elongated and tapering upwards.

It must be clearly understood that the following 'forms,' although apparently distinct when met with illustrating the extreme departure from the typical state, are in reality nothing more than phases of development of the present species in passing from north to south. The small, clustered form-Stevensoni, Berk.- is the most northern condition, of which there are specimens in the Kew Herbarium from Sweden (Fries), Finland (Karsten), Scotland (Stevenson), and New Hampshire, U.S. Then follows the typical form; further south we get chlorocephala, Sz., and finally passing into the warm subtropical region, we have stipitata (Bosc), (=viscosa, Fries), the largest and darkest coloured condition of the species. In Europe what I have considered the typical form is most abundant, the 'forms' being rarer, although all are present; whereas in the United States the opposite conditions hold good, so far as is at present known, the three darkgreen forms being not uncommon, whereas there are but few records of the typical form.

\section{Form Stevensoni.}

Usually densely tufted, small, entire fungus $2-3 \mathrm{~cm}$. high ; ascigerous portion dingy, dark green; stem paler. Asci, spores, and paraphyses as in typical form.

Syn.-Leotia Stevensoni, Berk. and Broome, Ann. Nat. Hist., I 879 , p. 2 I 2 .

Leotia chlorocephala, forma Stevensoni, Phil., Brit. Disc. 24, 1887 ; Sacc., Syll. viii, n. 251 I, I889; Massee, Brit. Fung.-Fl. iv, 472, 1895 .

Hab.-On the ground in woods and shady places, mostly in northern countries. 


\section{Massee.-A Monograph of the Geoglosseae.}

Distr.-Scotland (Glamis, Stevenson), Sweden (Upsala, Fries), Finland (Karsten), United States (New Hampshire).

\section{Form chlorocephala.}

Usually tufted, entire fungus 4-6 $\mathrm{cm}$., high, every part dark, dingy green. Asci, spores, and paraphyses as in the typical form.

Syn.-Leotia chlorocephala, Schwz., Syn. Fung. Carol., in Soc. Nat. Cur. Lips., I 822 , p. 88 (in extract) ; Fries, Syst. Myc. ii, 30, I823; Cooke, Mycogr. 98, fig. r74, 1875; Phil., Brit. Disc. 23, r887; Sacc., Syll. viii, n. 25II, I889; Massee, Brit. Fung.-Fl., iv, 47 I, I 895 .

Exs.-Rav., Fung. Carol. iv, n. 22 ; Ellis and Everh., N. Amer. Fung. ser. ii, n. $203^{2}$.

Hab.- On the ground in woods, \&c.

Distr. - South of England (New Forest, Hampshire, Miss Broadwood; Bournemouth, Massee; Surrey), United States (S. Carolina, Ravenel, n. I633; Pennsylvania, Michener, n. 3979; Salem, Schweinitz; Massachusetts ; Jacksonville, Florida, Calkins; California, Harkness, n. I2 16), Guiana (Leprieur, n. 1073).

Form stipitata. (Pl. XIII, Fig. 65.)

Scattered or gregarious, entire fungus $5^{-9} \mathrm{~cm}$. high; ascigerous portion irregularly waved or lobed, dark, lurid green, up to $2.5 \mathrm{~cm}$. broad; stem stout, more or less sulcate or lacunose, yellowish, brownish, or green. Asci, spores, and paraphyses as in the typical form.

Syn.-Tremella (Hygromitra) stipitata, Bosc, Berl. Mag. Nat., I 8 I I, 80 , tab. 6, f. I 4 .

Hygromitra stipitata, Nees, Syst. I8I7, 40, tab. xv, f. I44 (after Bosc).

Leotia viscosa, Fries, Syst. Myc. ii, 30, I823; Cooke, Mycogr. 98,

f. I 73, I 875 ; Sacc., Syll. viii, n. 2514, I889.

Leotia lubrica, var. viscosa, Quélet, Enchirid. 266, I 886.

Exs.-Ravenel, Fung. Amer. n. I73; Ellis, N. Amer. Fung. n. 663 .

Hab.--Sandy ground.

Distr.-France (Quélet), United States (South Carolina, Ravenel, nn. 702, I 784, 2315, 2976; Salem, Schweinitz).

The following note accompanies Ravenel's specimens, n. I 784 :- 
'Pileus convex, undulate, not so viscous as $L$. lubrica; dark green, $\frac{1}{2}-\frac{3}{4}$ in. broad. Stem hollow, thick or compressed and sulcate, expanding into pileus, covered with a greenish powder, the cavity filled with a gelatinous matter. Sometimes caespitose, in clusters of $2-3-4$; growing in light sand beds, mostly preferring roads but little used, generally only the pileus appearing above ground. Autumn and winter. This is probably the plant which Bosc describes as Tremella stipitata (Leotia viscosa, Fr.) ; I think it is a large state of L. chlorocephala. Found in Aiken and in the Santee Canal, S. Car.'

When of large size, this form appears to be very distinct, but it passes back by every transition into chlorocephala, as observed by Ravenel; and when the stem is yellowish, some forms approach the typical form in general appearance.

The most pronounced features of the species, including its forms, are : very slender, branched paraphyses with small piriform tips, ascus and spore-measurements as given in the diagnosis, and the minutely granulose or squamulose stem, which appears to be pulverulent as seen with the naked eye. When the stem is pale coloured, the granules are whitish; when dark coloured, they are green. See note under $L$. atrovirens.

Specimens of the typical form named by Persoon examined.

Leotia marcida, Pers., Syn. 6r 3, 180г ; Pers., Myc. Eur. i, 202, 1822 ; Fries, Syst. Myc. ii, 28, I823. (Pl. XII, Figs. 18-20.)

Fasciculate or gregarious, somewhat gelatinous when moist; ascigerous portion pileate, convex then becoming irregular, often more or less umbonate, margin incurved, wavy, concave below, thin, yellow, about $\mathrm{I} \mathrm{cm}$. broad; stem 4-10 $\mathrm{cm}$. long, 2-4 $\mathrm{mm}$. thick, wavy, equal or tapering downwards, coloured like the pileus, every part glabrous. Ascus narrowly clavate, apex narrowed and the wall thickened, not blue with iodine, I40-I50XII-I $2 \mu$; spores 8,2 -seriate above, I-seriate below, fusiform, ends rather acute, usually slightly curved,

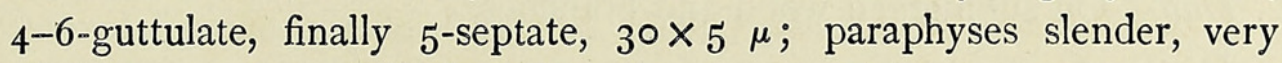
slightly or not at all thickened at the apex, straight.

Syn.-Phallus marcidus, Müll., Flor. Dan., tab. 654, f. I, I 775 .

Cudonia marcida, Quél., Enchirid. 267, 1886 (?).

Cudoniella marcida, Sacc., Syll. viii, n. I32, I889.

$H a b$. - On the ground among moss, \&c.

Distr.-France, Denmark. 


\section{Massee,-A Monograph of the Geoglosseae.}

The above description is drawn up from specimens in the Kew Herbarium, which were collected by Bulliard in the forest of Compiègne, and named by Persoon.

Distinguished from Leotia lubrica by the unbranched paraphyses, not being thickened at the apex, and the much more slender build of the ascophore, which is not green.

Very slightly subtremellose, not greenish yellow. Agreeing admirably with the figure in Fl. Dan., tab. 654 , except that I have not seen the stem more than 2 inches long. The name is also excellent, the whole substance dry, resembling leather; tomentose but not veined on the under surface (Wahlenb.).

Gregarious, slender, slightly gelatinous; not greenish, neither in the specimens I have seen, nor in an unedited figure in the library of Hornemann. Stem 3-4 in. long, I-2 lines thick, crooked. Pileus $\frac{1}{2}$ in. broad, rarely more, subumbonate, margin inflexed, wavy, concave and same colour underneath (Fries).

Leotia aquatica, Libert, in Roumeg., Fung. Sel. Gall. Exs., n. 639 (with diagnosis), I880; Pat., Tab. Anal. Fung. 32, fig. 75, 1883. (Pl. XII, Figs. 2 I-2 2.)

Gregarious; ascigerous portion convex at first, then plane or somewhat depressed, margin slightly incurved, rufous, glabrous, 3-6 $\mathrm{mm}$. broad, rather fleshy; stem slender, $\mathbf{I}-2 \mathrm{~cm}$. long, often flexuous, white, cylindrical, glabrous, base tomentose. Ascus clavate, apex slightly narrowed, not blue with iodine, about $70 \times 8 \mu$; spores 8,2 -seriate above, becoming I-seriate below, elliptical, ends narrowed, sometimes slightly curved, II-I $4 \times 4 \mu$; paraphyses slender, slightly clavate and brownish at the tips, more or less agglutinated together.

Syn.-Cudonia aquatica, Quélet, Enchirid. 267, 1886.

Cudoniella aquatica, Sacc., Syll. viii, n. I35, I889; Rehm., Kr.-Fl., n. $5^{884}, \mathrm{I} 896$.

Hab.-On submerged wood and branches.

Distr.-Germany, France.

Schröter (Krypt.-Flora von Schlesien, iii, pt. ii, p. 2 I) says the ascigerous portion is 'white when fresh, brownish when dry'; this statement is repeated by Rehm. Both these authors also give the same spore-measurements $(7-9 \times 2-3 \mu)$, which are less than those found on examining Madame Libert's specimens. 


\section{Massee.-A Monograph of the Geoglosseae.}

Leotia stagnalis, Massee.

Ascigerous portion convex, orbicular, the free margin incurved, glabrous, waxy, rather firm, yellowish flesh-colour, then dingy, 4-5 $\mathrm{mm}$. diameter; stem slender, apex grooved, pale ochraceous, base tinged olive, I-I.5 $\mathrm{cm}$. long, scarcely I mm. thick. Asci (?); spores continuous, narrowly elliptic, 2 -guttulate, I 2-I $4 \mu$ long.

Syn.-Cudonia stagnalis, Quél., Assoc. Franç. xii, r 883 , r 3, pl. 7, f. 1 o. Cudoniella stagnalis, Sacc., Syll. viii, n. I34, 1889 .

$H a b$.-On leaves and decaying vegetable matter on the margins of swamps.

Distr.-Germany (Alsace, Quélet).

\section{Doubtful Species.}

Leotia platypoda, Pers., Myc. Eur. i, 202, 1822 ; Fries, Syst. Myc. ii, 28, 1823; Sacc., Syll. viii, n. 25 I3, I889.

This species was first described by De Candolle (Flor. Franç. vi, 29, I8I5) as follows: 'This species of Helvella is one of the smallest of the genus, and rarely reaches more than six lines high; its consistence is gelatinous, slightly coriaceous; the pedicel is entirely compressed, of a dirty white colour, terminated by an irregularly wrinkled or undulated, small, brownish cap, the margin slightly turned down. M. Aubin found this fungus growing on the ground in the neighbourhood of Grasse, in Provence.'

Syn.-Helvella platypoda, De Candolle, Flor. France, vi, 29, I 8 I 5 .

$H a b$. - On the ground.

Distr.-France.

The above description does not convey a very clear conception as to what the species was like that De Candolle had in view. Patouillard (Tab. Analyt. Fung. n. 447) had figured and described a fungus which he considers to be the species of De Candolle, collected by MM. Bommer and Rousseau, near Brussels. His description is as follows:-

'Fungus I-2 cm. high. Pileus gelatinous, wrinkled, undulated, russet. Stem compressed at the summit, attenuated below, whitish. Asci containing eight spores, 2-seriate; spores elongated, clavate, 3-4-guttulate, hyaline ; paraphy ses branched.'

According to the figure the spores are narrowly cylindric-clavate, $2 \mathrm{I}-22 \times 5^{-6} \mu$. 


\section{Massee.-A Monograph of the Geoglosseae.}

Leotia verpoides, Massee.

Ascigerous portion discoid, rotund, yellowish, margin entire, recurved, disk dry, wrinkled, even below, pallid, $4 \mathrm{~mm}$. broad; stem 2-3 cm. long, $2 \mathrm{~mm}$. thick, dilated, contorted, brown.

Syn.-Peziza verpoides, Sauter, Hedw., I876, I 49.

Phialea verpoides, Sacc., Syll. viii, n. I081, 1889.

Cudoniella verpoides, Rehm, Kr.-Fl., n. 5886, I 896.

Hab.-On rotten beech wood.

Distr.-Germany (Salsburg).

This species may possibly prove to belong to Helotium rather than to Leotia.

Leotia rufa, Rostrup, Fung. Groenl. 536, I888; Sacc., Syll. viii, n. 25 I7, I889.

Ascigerous portion wavy, margin revolute, $\mathbf{I}-\mathbf{2} \mathrm{mm}$. broad, rufous; stem unequally terete, rufo-ferruginous, 5-6 mm. high. Asci tereteclavate, pedicellate, $60-70 \times 2 \mu$; spores (?).

Hab.-Among moss.

Distr.-Greenland (Agdluitsok).

Leotia fructigena, Massee.

Ascigerous portion hemispherical, ochraceous, I $\mathrm{mm}$. diameter; stem I cm. high, $0.5 \mathrm{~mm}$. thick, white. Asci $200-220 \times 6-7 \mu$; spores $25-45 \times 5 \mu, \mathrm{I}-3$-septate, hyaline.

Syn.-Cudoniella fructigena, Rostrup, Meddel. om Groenland, iii, 591, I 891 ; Sacc., Syll. Suppl. xi, n. 2407 , r 895 .

Hab.-On fruits of Archangelica officinalis.

Distr._Greenland.

Judging from the habitat, this species may prove to belong to the genus Helotium.

Leotia elegantula, Kalchbr., Grev. x, I 43, I 882 ; Sacc., Syll. viii, n. 25 I 6, I 889 .

Subsolitary; ascigerous portion the size of a pea, convex, margin involute, somewhat shining, blackish brown with a purple tinge; rugose and almost lamellose below, ochraceous tan; stem cylindrical, equal, base dilated, pulverulent, ochraceous tan, $2.5 \mathrm{~cm}$. long, $3 \mathrm{~mm}$. thick. Spores shortly ovate, tinged brown, translucent, $9 \times 6 \mu$.

Hab.-(?)

Distr.-S. Africa (Somerset East, MacOwan, n. I3 1о). 
Apparently a very remarkable species, respecting which more requires to be known. If the spores are truly coloured, the fungus cannot remain in the present genus, neither does it agree with any other genus at present established.

\section{Spragueola, Massee.}

Ascophore sessile, subglobose, irregularly nodulose, glabrous, solid, hymenium covering the entire surface, attached to the substratum by radiating mycelium. Asci narrowly cylindric-clavate, apex slightly truncate or cbicse, pore blue with iodine; spores 8, obliquely I-seriate, continuo $\approx$, hyaline, smooth, elliptical; paraphyses slender, septate.

Spragueola, Massee, Journ. Bot. xxxiv, 1 44, pl. 357, figs. 8-9, r 896.

Mitrula, Berk., Grev. iii, I49, 1875 .

The validity of the present genus is not entirely beyond doubt, partly owing to the fact that, so far as I am aware, only two specimens are known; these are in the Kew Herbarium. Differs from every other genus included in the Geoglosseae in being absolutely sessile, the ascophore being irregularly globose, coarsely nodulose, solid, and everywhere covered by the hymenium. Mitrula is the genus most nearly approached in the structure of the asci and spores.

Distr.-One species; United States.

Spragueola americana, Massee, Journ. Bot. xxxiv, I 44, pl. 357 , figs. 8, 9, I 896 . (Pl. XIII, Figs. 74, 76.)

Ascophore subglobose, attached by a broad base, coarsely nodulose, glabrous, $\mathbf{I} \cdot 5^{-2} \cdot 5 \mathrm{~cm}$. high and broad, pale ochraceous tan (when dry), fleshy, solid, internally white. Asci narrowly cylindricclavate, apex obtuse, pore blue with iodine, $70-80 \times 5^{-6 \mu}$; spores 8 , obliquely I-seriate, continuous, hyaline, elliptical, smooth, ends obtuse, $6.5-7 \times 3.5 \mu$; paraphyses slender, septate, slightly clavate, straight.

Syn.-Mitrula crispata, Fries, Berk., N. Amer. Fung. n. $704^{*}$, in Grev. iii, I42, 1875 .

$H a b .-O n$ the ground among pine leaves.

Distr.-United States (New England, Sprague, n. 5785).

As to what Spathularia crispata, Fries, really is, we shall never know, as it has not been described. In first mentioning the nameSumm. Veg. Scand. $347(1846)$-Fries, in contrasting it with S. flavida, says, 'A priori distinctissima!' Fuckel accepts as the species of 


\section{Massee.-A Monograph of the Geoglosseae.}

Fries a Spathularia differing from $S$. flavida in having slightly different spores, measuring $48 \times 3 \mu$, whereas his measurements for S. flavida are $72 \times 2 \mu$ (Symb. Myc. 332). Berkeley, on the other hand, considered the New England fungus communicated by Sprague to represent $S$. crispata of Fries, but, observing that the spores were elliptical, placed it in the genus Mitrula, without, however, giving a diagnosis, but simply stating, 'Sporidia elliptic, uniseriate.' As the fungus under consideration is neither a Spathularia nor a Mitrula, neither does it accord with any hitherto defined genus, it is named after its discoverer, one of the pioneers of $\mathrm{N}$. American botany (Massee, Journ. Bot. l. c.).

\section{Hemiglossum, Pat.}

Ascigerous portion gelatinous, coriaceous, simple or branched, tongueshaped or convolute, stipitate; hymenium unilateral; asci elongated, opening by a pore; spores 8 , small, ovoid or fusoid, hyaline.

Hemiglossum, Patouillard, Rev. Myc. I890, I35; Sacc., Syl. Suppl. x, p. 2, 1892 .

Distinguished at once from all other genera by the more or less incised vertical ascigerous portion having the hymenium developed on one surface only, the other surface remaining sterile. This differentiation of surfaces is also met with in Leotia and Vibrissea, but in both these genera the ascigerous portion is pileate and horizontal, the upper surface being fertile, the under surface sterile. Hemiglossum is analogous in the arrangement of its hymenium with Skepperia and Lachnocladium, genera belonging to the Basidiomycetes.

Distr.-Only one species known, China.

Hemiglossum Yunnanense, Pat., Rev. Myc. I 35, pl. cvii bis, fig. 2, r89o; Sacc., Syll. Suppl. x, n. 4468, I892. (Pl. XIII, Figs. 83, 84.)

Ascigerous portion simple or branched, more or less incised or lobed, margin revolute below or all round, thin, about $\mathrm{I} \mathrm{mm}$. thick, I0-I $5 \mathrm{~mm}$. long, 4-8 $\mathrm{mm}$. broad, smooth, tawny; concave sterile face paler, furfuraceous owing to the presence of tufts of ovoid, brown cells; stem rigid, slender, straight or flexuous, reddish brown, $\mathbf{I}-2 \mathrm{~cm}$. long, 2-4 mm. thick. Asci stipitate, elongated, apex obtuse, becoming tinged blue round the pore with iodine, $55^{-60 \times 4 \mu}$; spores 8 , I-seriate, hyaline, continuous, fusoid, ends rather acute, 2 -guttulate, $6-7 \times 1 \cdot 5^{-2} \mu$; paraphyses linear, simple, hyaline. 
Hab.-On the ground (?).

Distr.-China (Tsang-chan, above Ta-li, M. l'abbé Telavay).

A very remarkable species, the type of structure being unique. I once met with what appeared to be at first sight a structure agreeing exactly with that described above, and was on the point of describing it as a new genus, when I discovered that it was simply a Mitrula, the ascigerous portion of which had been crushed and burst open, thus presenting a flattened expansion, more or less incised, and with one surface fertile and the other sterile. I have no evidence that such is the explanation in the present instance.

\section{NEOLECTA, Speg.}

Ascigerous portion sharply defined, terminal on a stem with which it is hornogeneous, terete or spathulato-compressed, bright coloured. Asci cylindrical, 8-spored; spores globose, hyaline, simple; paraphyses absent.

Neolecta, Spegazzini, Fung. Argent., Pug. iv, in Anal. Soc. Cient. Argentina, tom. ix, 83, I880; Sacc., Syll. viii, 40, I889.

Agreeing in general habit with the genera Mitrula and Spathularia, but di: tinguished from these and every other genus by the globose spores.

Distr.-One species, confined to Brazil.

Neolecta flavo-virescens, Speg., Fung. Arg., Pug. iv, Anal. Soc. Cient. Argentina, ix, 83, I880; Sacc., Syll. viii, n. I3 1 , I889. (Pl. XIII, Figs. 89, 90.)

Ascigerous portion irregularly cylindrical or clavate-compressed, often spathulate, apex obtuse or wavy and rounded, base more or less distinct, narrowed into the stem, $15^{-2} 5 \mathrm{~mm}$. high by $2-5 \mathrm{~mm}$. broad; thickish, somewhat elastic and fleshy, even, quite glabrous, rarely here and there grooved and plicate, very bright greenish-yellow ; stem subterete, continuous and homogeneous with the fertile portion, even or minutely rugulose, paler, minutely and irregularly rooting below, 4-10 $\mathrm{mm}$. long, $\mathrm{I}-\mathrm{I} \cdot 5 \mathrm{~mm}$. thick. Asci cylindrical or cylindricsubclavate, apex very obtuse, narrowed below into a long, slender pedicel, $80-85 \times 5-6 \mu$; iodine gives no blue colour, wall of ascus everywhere thin, dehiscing by an operculum; spores 8 , globose, hyaline, with I large, eccentric oil globule, hyaline, $4-5 \mu$ diameter. 


\section{Massee.-A Monograph of the Geoglosseae.}

Hab.-Among heaps of rotten leaves and twigs.

Distr.-Brazil (Apiahy, Puiggari, n. I544). A fragment of this species was also found among specimens of other fungi sent from Brazil by Glaziou.

\section{EXCLUDED SPECIES.}

The following are excluded as belonging to genera not included in the Geoglosseae as defined in the present work:-

Vibrissea microscopica, Berk. and Broome, Ann. Nat. Hist. ser. 4, xvii, 142, 1876; Phil., Trans. Linn. Soc. (Bot.) ser. 2, ii, 7, pl. I, f. I7-24, I881 ; Phil., Brit. Disc. 319, I887; Sacc., Syll. viii, n. I75, I889; Massee, Brit. Fung.-Fl. ix, 489, I 895 .

This species does not exhibit the characters of Vibrissea, and should henceforth be known as Gorgoniceps microscopica (B. and $\mathrm{Br}$.).

Vibrissea turbinella, Sacc., Syll. viii, n. I 74, I889.

Syn.-Peziza turbinella, Berk., Dec. Fung. n. 358, in Hook., Journ. Bot. iii, I 85 I.

Peziza stilboidea, Berk., Dec. Fung. n. 359, in Hook., Journ. Bot. iii, 185 r.

Vibrissea stilboidea, Sacc., Syll. viii, n. I 76, I 889 .

The types of both the supposed species have been examined, and prove to be identical. The fungus is a typical Pocillum, and should stand as $P$. turbinellum (B.).

Vibrissea pezizoides, Libert, ms., in Phil., Gen. Vibrissea, Trans. Linn. Soc. (Bot.) ser. 2, ii, 8, pl. 2, f. 8-I3, I881 ; Sacc., Syll. viii, n. I 72, I 889 .

Saccardo has a query as to whether this species is not a Gorgoniceps, and on examining the type I find that he was correct; the species will rank as Gorgoniceps pezizoides (Lib.).

Vibrissea Guernisaci, Crouan, Ann. Sci. Nat. vii, I76, t. 4, f. 24-26, 1857 ; Phil., Gen. Vibrissea, Trans. Linn. Soc. ser. 2, ii, 8, pl. 2, f. I-7, 1881 ; Phil., Brit. Disc. 319, pl. 1о, f. 61, 1887; Massee, Brit. Fung.-Fl. iv, 488, I 895 .

Gorgoniceps Guernisaci, Sacc., Syll. viii, n. 2082, 1889.

Saccardo is correct in placing the present species in the genus Gorgoniceps. 
Vibrissea leptospora, Phil., Trans. Linn. Soc. (Bot.), ser. 2, ii, 8, pl. 2, f. 19-23, I881 ; Phil., Brit. Disc. 320, 1887 .

Syn.-Peziza leptospora, Berk. \& Broome, Ann. Nat. Hist. ser. 3, xviii, I 2, tab. 4 , f. 30, I 866 .

Vibrissea Guernisaci, var. leptospora, Massee, Brit. Fung.-Fl. iv, 488, 1895 .

Gorgoniceps leptospora, Sacc., Syll. viii, n. 2086, I 889 .

Vibrissea Fergussoni, Phil., Trans. Linn. Soc. (Bot.), ser. 2, ii, 7 , I88 I ; Phil., Brit. Disc. 3 I 8, I887 ; Sacc., Syll. viii, n. I73, I889.

Patellaria Fergussoni, Berk. \& Broome, Ann. Nat. Hist. p. 39, pl. iv, f. 30,1875 .

Gorgoniceps vibrisseoides, Sacc., Syll. viii, n. 2084, 1889.

Gorgoniceps turbinata, Sacc., Consp. Gen. Disc. 7 .

Helotium vibrisseoides, Peck, 3 2nd Rep. N. Y. State Mus. 48, 1879; Peck, Bull. N. Y. State Mus. I887, p. 28, pl. 2, f. 7-9.

Vibrissea turbinata, Phillips, Gen. Vibrissea, Trans. Linn. Soc. (Bot.), ser. 2, ii, 8, pl. 2, f. I4-I 8, I88 I.

Vibrissea Guernisaci, var. vibrisseoides, Massee, Brit. Fung.-Fl. iv, 488, I 895 .

Patellaria recisa, Berk. \& Curt., in Cooke's Discom. of U. S., pt. ii, in Bull. Buff. Soc. Nat. Sci. $27, \mathbf{1} 876$; Sacc., Syll. viii, n. 324 r, I 889 .

In Brit. Fung.-Flora, iv, 488, I have considered leptospora and vibrisseoides as varieties of Guernisaci; however, on re-examining a larger series of specimens, I find that the slender varietal characters on which I depended are not constant, and there is no doubt but that leptospora, Fergussoni, vibrisseoides, turbinata, and recisa are identical with, and synonyms of, Gorgoniceps Guernisaci, Sacc.

There is a note in Dr. Cooke's handwriting in Herb. Kew, stating that Helotium vibrisseoides, Peck, is identical with Patellaria filifera, B. \& C. I have no knowledge of either specimen or description of the last-named species, and mention this so that, if such a species is extant, its affinities may be known.

Mitrula mucerdae, Fries, Syst. Myc. i, 492, I82 I ; Sacc., Syll. viii, n. I I I, I 889 .

Syn.-Clavaria mucerdae, Schum., Saell. 405, I801.

Fries states (Elench. i, 235) that he afterwards saw this species, which proved to be a Stilbum. 
300 Massee.-A Monograph of the Geoglosseae.

Mitrula inflata, Fries, Elench. i, 234, I828; Sacc., Syll. viii, n. I I 2, I889; Leotia inflata, Schweinitz to Fries in litt.

Spathularia inflata, Cke., Mycogr. f. 344, 1879.

This species belongs to the Clavarieae, and is known as Physalacria inflata, Peck, Bull. Torr. Bot. Club, 1882, p. 2.

Mitrula minuta, Fries, Syst. Myc. i, 492, I82 I ; Clavaria minula, Sow., Eng. Fung. tab. 391, I803.

Probably a condition of Pistillaria micans, as suggested by Berkeley, Eng. Flora, v, I80.

The following are excluded on account of the impossibility of determining the species intended from the brief diagnoses given; and unless type specimens exist, the names should be no longer allowed to encumber mycological literature.

Leotia unctuosa, Fries, Syst. Myc. ii, 31, I823; Sacc., Syll. viii, n. 2522, r $889 ;$ Rehm, Kr.-Fl. n. 5882, 1896.

Syn.-Elvella unctuosa, Batsch, Elench. Fung. i, 193, f. I34, I783.

The brief description of five words, even aided by the minute figures, has not enabled any one to identify this species with certainty, hence it always appears in the list of uncertain species.

Leotia amara, Fries, Syst. Myc. ii, 27, I823; Sacc., Syll. viii, n. 2521,1889 .

Syn.-Helvella amara, Loureiro, Flor. Cochinch. i, 695, I 790.

Leotia nana, Fries, Syst. Myc. ii, 28, 1823; Phil., Brit. Disc. 26, I887; Sacc., Syll. viii, n. 2522, 1889.

Syn.-Helvella nana, Withering, Arr. Brit. Pl., ed. iv, iv, 23I, 1801 .

Leotia brunneola, Berk. and Broome, Fungi of Ceylon, in Journ. Linn. Soc. (Bot.) xiv, I02, I875; Sacc., Syll. viii, n. $2520,1889$.

Very briefly described from a poor sketch, and no specimens preserved.

Leotia infundibuliformis, Fries, Obs. ii, 299, 1818; Sacc., Syll. viii, n. 2519, I889.

Syn.- Helvella infundibuliformis, Schaeff., Fung., tab. 277, I 762; Sowerby, Eng. Fung. pl. I 53, I 799. 


\section{Massee.-A Monograph of the Geoglosseae. 301}

Leotia atra, Weinm., Syll. Pl. Nov. ii, Io9, I 828 ; Fries, Elench. ii, 3, I828; Sacc., Syll. viii, n. 25 I 8, I889.

Geoglossum farinaceum, Schwz., Fung. Carol. n. I1 16, I822 ; Sacc., Syll. viii, n. I54, I889.

The description obviously refers to the conidial condition of some Hypoxylon, but specimens alone can settle the species, the diagnosis being too brief.

Geoglossum rugosum, Lasch; Sacc., Syll. viii, n. I55, 1889. According to Bot. Ztg., 1846 , 45, a specimen bearing this name occurs in Klotzsch-Rabenh., Herb. Myc. n. 8I6. As a matter of fact, the fungus in question does not occur as indicated, neither can any trace of a specimen bearing the above name be found; and furthermore, as it was never described, the name may be allowed to lapse.

Vibrissea flavipes, Rabenh., in Klotzsch-Rab., Herb. Myc. cent. xvii, n. 27 , I850; Bot. Ztg. I $85^{2}$, p. 286 ; Sacc., Syll. viii, n. I 7 I, I889; Rehm, Kr.-Fl. n. 589o, I896.

This species is synonymous with Coniocybe nivea, Rehm. 
302 Massee.-A Monograph of the Geoglosseae.

\section{INDEX.}

Cibalocoryne, 240.

- viscosula, 252.

Clavaria, 240, 253, 264, 286.

- epiphylla, 272.

- ferruginea, 276.

- minuta, 300.

- mitrata, 266.

- var. viridis, 269.

- mucerdae, 299.

- nigrita, 249.

- ophioglossoides, 24 I, 247.

- phalloides, 272.

- serpentina, 269.

- simplex hirsuta, $24 \mathrm{I}$.

- spathulata, 255.

- tremella, 288.

- viridis, 269.

Coniocybe nivea, 3 or.

Cudonia, 259, 285.

- aquatica, 292.

- circinans, $26 \mathrm{r}$.

- Intea, 262.

- marcida, $29 \mathrm{I}$.

- stagnalis, 293

Cudoniella, 285.

- aquatica, 292.

- fructigena, 294.

- marcida, 291.

- stagnalis, 293

- verpoides, 294.

Elvella, 253, 286.

- clavata, 255.

- cucullata, 276.

- lubrica, 288.

- unctuosa, 300.

Fungus gelatinosus fla. vus, 288.

Geoglossum, 240, 264.

- album, 285 .

- americanum, $24^{2}$.

- atropurpureum, 266.

- australe, 247.

- Barlae, 25 I.

- carneum, 270.

- cucullatum, 276 .

- difforme, 248.

- farinaceum, $30 \mathrm{I}$.

- Farlowi, 243.

- favum, 256, 275.

- glabrum, 246.
Geoglossum glabrum, fo difforme, 248.

_ - var. lignicolum, 250.

- glutinosum, 245,250 .

- f. minor, 245 .

- Heuflerianum, 253 .

- hirsutum, 241.

- - f. americanum, 242.

- $\mathrm{f}$. leotioides, 244 .

- f. velutipes, 243.

- f. Walteri, 243 .

- var. americanum, 242.

- - var. capitatum, 24I.

- var. leotioides, 244.

- Hookeri, 267.

- lignicolum, 250.

- luteum, 275.

- microsporum, 282.

- - var. tremellosum, 283.

- Mülleri, 245.

- multiforme, $28 \mathrm{r}$.

-- nigritum, 239.

- olivaceum, 270.

- - var. purpureum, 270.

- ophioglossoides, 247.

- - var.sphagnophilum, 247.

- f. Barlae, $25 \mathrm{I}$.

- f f. umbratile, $25 \mathrm{I}$.

- pistillaris, 275.

- pumilum, $25^{2}$.

- rufum, 275.

- rugosum, 3 OI.

- simile, 247.

- sphagnophilum, 247.

- tremellosum, 283 .

- umbratile, $25 \mathrm{I}$.

- velutipes, 244.

- viride, 269.

- viscosulum, $25^{2}$.

- viscosum, 245 .

- vitellinum, 273.

- Walteri, 243.

Gorgoniceps Guernisaci, 298.

- leptospora, 299.

- microscopica, 298.

- pezizoides, 298.

- turbinata, 299.
- Peckianum, 250.
Gorgoniceps vibrisseoides, 299.

Helotium, 259, 285.

- aciculare, 286.

- atrovirens, 287.

- circinans, 261.

- vibrisseoides, 299.

Helvella, 285 .

- amara, 300.

- feritoria, 255.

- Aavo-virens, 288.

- gelatinosa, 288.

- infundibuliformis,300

- laricina, 272 .

- lutea, 288.

- nana, 300.

- platypoda, 293.

- revoluta, $26 \mathrm{I}$.

- spathularia, 25.

- spathulata, 255 .

Hemiglossum, 296.

- Yunnanense, 296.

Hygromitrastipitata, 290.

- tremula, 288.

Lachnocladium, 296.

Leotia, 259, 285 .

- acicularis, 286.

- amara, 300.

- aquatica, $29^{2}$

- atra, $30 \mathrm{I}$.

- atrovirens, 286.

- brunneola, 300.

- Bulliardi, 272.

- chlorocephala, 290.

- - f. Stevensoni, 289.

- circinans, $26 \mathrm{I}$.

- clavius, 260.

- Dicksoni, 272.

- elegans, 274.

- elegantula, 294.

- exigua, 285.

- fructigena, 294.

- gelatinosa capitulo sub. viridi, 288.

- geoglossoides, 269. gracilis, 26I.

- inflata, 300.

- infundibuliformis, 300 .

- laricina, 272.

- lubrica, 287.

- f. chlorocephala, 290. 
Leotia lubrica, f. Stevensoni, 289.

- f. stipitata, 290.

- var. lacunosa, 287.

- var. laevis, $28 \%$.

- - var. revoluta, 287 .

- var. umbonata, 287.

- var. viscosa, 290.

- Ludwigii, 272.

- marcida, $29 \mathrm{I}$.

- mitrula, 276.

- - var. pusilla, 277.

- nana, 300.

- ochroleuca, 262.

- platypoda, 293.

- pusilla, 277.

- rufa, 294.

- stagnalis, 293.

- Stevensoni, 289.

- truncorum, 260.

- uliginosa, 272.

- unctuosa, 300.

- verpoides, 294.

- viridis, 269.

- viscosa, 300 .

Leptoglossum, ${ }^{2} 53,264$.

- flavum, 256.

- littorale, 283.

- luteum, 275 .

- microsporum, 282.

- olivaceum, 270.

- tremellosum, 283.

- viride, 269.

Merulius Iubricus, 288.

Microglossum, 264 .

- arenarium, 283 .

- atropurpureum, 267.

- Hookeri, 267.

- lutescens, $27 \mathrm{I}$.

- multiforme, 28r.

- olivaceum, 270.

- partitum, 284 .

- viride, 269.

Mitrula, 253, 263, 295.

- abietis, 276 .

- alba, 272 .

- alba, 284 .

- antarctica, 284.

- arenaria, 283.

- Berterii, 268.

- bicolor, 280.

- crispata, 295.

- cucullata, 276.

- elegans, 274.

- exigua, 285 .

- fusispora, 277.

- glabra, 266.
Mitrula globosa, 28I.

- gracilis, 278.

- Heyderi, 276.

- inflata, 300.

- Johnsoni, 285.

- laricina, $27 \mathrm{I}$.

- f. alba, 273 .

- lilacina, 257.

- lutea, 275 .

- luteola, 274.

- lutescens, $27 \mathrm{I}, 275$.

- microspora, 28I.

- - var. littorale, 283 .

- var.tremellosa, 282 .

- minuta, 300.

- mucerdae, 299.

- multiforme, 280.

- f. capitata, 280 .

- f. clavata, 280 .

- f. pileata, 280 .

- muscicola, 279.

- nigripes, 257.

- olivacea, 270.

- paludosa, 272.

- var. pachyceps, 272.

- partita, 283 .

- phalloides, 272.

- - var. alba, 273.

- pistillaris, 275 .

- purpurascens, 266.

- pusilla, 277.

- Rehmii, 279.

- rufa, $258,275$.

- Saccardoa, 268.

- sclerotiorum, $28 \mathrm{r}$.

- sclerotipes, 278 .

- serpentina, 268.

- spathularia, 300.

- spathulata, 255.

- sphaerocephala, 277 .

- vinosa, 268.

- viridis, 269.

— vitellina, 273 .

Neolecta, 297.

- flavo-virescens, 297.

Patellaria, 299.

- Fergussoni, 299.

- filifera, 299.

- recisa, 299.

Peziza, 286.

- cormucopiae, 288.

- leptospora, 299.

- stilboidea, 298.

- turbinella, 298.
Peziza verpoides, 294.

Phallus, 286.

- marcidus, $29 \mathrm{I}$.

Phialea verpoides, 294.

Physalacria inflata, 300 .

Pistillaria micans, 300.

Pocillum turbinellum, 298.

Podonia circinans, $26 \mathrm{I}$.

Spathularia, 253 .

- clavata, 254.

- crispata, 295.

- flava, 255.

- flava, 255.

- flavida, 255.

- - var. crispa, 255 .

- var. plicata, 255.

- inflata, 300.

- Neesii, 258.

- nigripes, 257.

- rufa, 257,258 .

- - var. badipes, $25^{8}$

- velutipes, 256 .

Spathulea, 253.

- rufa, 258.

Spragueola, 295.

- americana, 295.

Tremella, 286.

- stipitata, 290.

Trichoglossum, 240.

- hirsutum, $24 \mathrm{I}$.

Verpa, 264 .

- ferruginea, 276.

Vibrissea, 259.

- circinans, $26 \mathrm{I}$.

- Fergussoni, 299.

- flavipes, 30I.

- Guernisaci, 298.

- var. leptospora, 299.

- - var. vibrisseoides 299.

- leptospora, 299.

- lutea, 262.

- Margarita, 260.

- microscopica, 298

- ochroleuca, 262.

- pezizoides, 298.

- recisa, 299.

- rimarum, 263.

- stilboidea, 298.

- truncorum, 260.

- - var. albipes, 260.

- turbinata, 299.

- turbinella, 298.

— vermicularis, 263 . 


\title{
EXPLANATION OF FIGURES IN PLATES XII AND XIII.
}

\author{
Illustrating Mr. Massee's Monograph of Geoglosseae.
}

\section{PLATE XII.}

Fig. I. Geoglossum glabrum, var. lignicolum. Nat. size.

Fig. 2. Spore of same. $\times 400$.

Fig. 3. Mitrula vitellina, Sacc. Nat. size (after Bresadola).

Fig. 4. Section of same. Nat. size.

Fig. $4 a$. Asci and paraphysis of same. $\times 400$.

Fig. 5. Vibrissea lutea, Peck. Nat. size.

Fig. 6. Ascus and paraphyses of same. $\times 400$.

Fig. 7. Spores of same. $\times 400$.

Fig. 8. Geoglossum hirsutum, form leotioides, Massee. Nat. size.

Fig. 9. Section of same. Nat. size.

Fig. I0. Ascus, paraphysis, and cystidium of same. $\times 400$.

Fig. II. Apex of ascus of same, showing the apical pore, $a$, which becomes blue when treated with a solution of iodine. $\times 75^{\circ}$.

Fig. 12. Spore of same. $\times 400$.

Fig. I3. Vibrissea circinans, Hazsl. Nat. size.

Fig. I4. Spores of same. $\times 400$.

Fig. I 5. Vibrissea truncorum, Fries. Nat. size.

Fig. 16. Specimen of same. Slightly enlarged.

Fig. I7. Section of same. Slightly enlarged.

Fig. I 7 a. Ascus, paraphysis, and free spore of same. $\times 400$.

Fig. I8. Leotia marcida, Pers., group of plants. Nat. size.

Fig. I9. Ascus and paraphyses of same. $\times 400$.

Fig. 20. Free spores of same. $\times 400$.

Fig. 21. Leotia aquatica, Libert. Nat. size.

Fig. 22. Ascus and paraphyses of same. $\times 400$.

Fig. 23. Mitrula luteola, Ellis. Nat. size.

Fig. 24. Paraphysis and asci in various stages of development of same. $\times 400$.

Fig. $24 a$. Free spores of same. $\times 400$.

Fig. 25. Spathularia fava, Mass. Nat. size (after Gillet).

Fig. 26. Ascus with spores of same (after Gillet. No $\times$ given).

Fig. 27. Mitrula purpurascens, Mass. Nat. size.

Fig. 28. Mitrula rufa, Sacc. Nat. size.

Fig. 29. Ascus and paraphysis of same. $\times 400$.

Fig. 30. Free spores of same. $\times 400$.

Fig. 3I. Geoglossum hirsutum, Pers. Nat. size.

Fig. $3^{1} a$. Ascus containing a fascicle of eight spores, paraphyses, and black spine-like cystidium, of the same species. $\times 400$.

Fig. 32. Free spore of same. $\times 400$.

Fig. 33. Mitrula Berterii, Mont. Nat. size. 


\section{Massee.-A Monograph of the Geoglosseae.}

Fig. 34. Asci and paraphysis of same. $\times 400$.

Fig. 35. Free spores of same. $\times 400$.

Fig. 36. Spathularia rufa, Swartz. Nat. size.

Fig. 37. Ascus and paraphyses of same. $\times 400$.

Fig. 38. Free spores of same. $\times 400$.

Fig. 39. Mitrula cucullata, Fries. Nat. size.

Fig. 40. Ascus and paraphysis of same. $\times 400$.

Fig. 4I. Free spores of same. $\times 400$.

Fig. 42. Ascus and paraphyses of Geoglossum Peckianum, Cke. Nat. size.

Fig. 43. Free spore of same. $\times 400$.

Fig. 44. Geoglossum glabrum, Pers. Nat. size.

Fig. 45. Ascus and paraphyses of same. $\times 400$.

Fig. 46 . Free spore of same. $\times 400$.

Fig. 47. Mitrula pusilla, Fries. Nat. size.

Fig. 48. A single plant of same. Slightly $x$.

Fig. 49. Section of same. Slightly $x$.

\section{PLATE XIII.}

Fig. 50. Spathularia clavata, Sacc. Nat. size.

Fig. 5I. Ascus and paraphyses of same. $\times 400$.

Fig. 52. Free spores of same, showing the outer gelatinous sheath. $\times 400$.

Fig. 53. Young ascus, paraphyses, and portion of hypothecium of same, showing protoplasmic continuity. $\times 75^{\circ}$.

Fig. 54. Mitrula globosa, Sommerf. Nat. size (after Sommerfeldt).

Fig. 55. Mitrula microspora, Massee. Nat. size.

Fig. 56. Ascus and paraphyses of same. $\times 400$.

Fig. 57. Free spores of same. $\times 400$.

Fig. 58. Mitrula multiforme, Massee, form clavata. Nat. size (after Henning).

Fig. 59. Form capitata of same. Nat. size (after Henning).

Fig. 6o. Form pileata of same. Nat. size (after Henning).

Fig. 6I. Leotia lubrica, Pers. Nat. size.

Fig. 62. Ascus and paraphysis of same. $\times 400$.

Fig. 63. Free spores of same. $\times 400$.

Fig. 64. Apex of ascus of same, showing the mode of dehiscence. $\quad \times 400$.

Fig. 65. Leotia lubrica, Pers., form stipitata. Nat. size.

Fig. 66. Geoglossum glutinosum, Pers.; ascus and paraphyses. $\times 400$.

Fig. 67. Spores of same. $\times 400$.

Fig. 68. Mitrula serpentina, Massee. Nat. size.

Fig. 69. Mitrula laricina, Massee. Nat. size.

Fig 70. Vibrissea ochroleuca, Massee. Nat. size.

Fig. 7 I. Ascus and paraphysis of same. $\times 400$.

Fig. 72. Free spores of same. $\times 400$.

Fig. 73. Mitrula muscicola, Henn. Nat. size (after Henning).

Fig. 74. Spragueola americana, Massee. Nat. size.

Fig. 75. Section of same. Nat. size.

Fig. 76. Ascus and paraphysis of same. $\times 400$.

Fig. 77. Mitrula lutescens, Massee. Nat. size.

Fig. 78. Geoglossum hirsutum, form Walteri. Nat. size. 


\section{Massee.-A Monograph of the Geoglosseae.}

Fig. 79. Ascus, paraphyses, and spine-like cystidium. $\quad \times 400$.

Fig. 80. Spore of same. $\times 400$.

Fig. 81. Leotia atrovirens, Pers. Nat. size.

Fig. 82. Section of same. Nat. size.

Fig. 83. Hemiglossum Yunnanense, Pat., two plants. Nat. size (after Patouillard).

Fig. 84. Section of ascigerous portion, showing the hymenium covering the convex side only. Slightly $\times$ (after Patouillard).

Fig. 85. Spathularia velutipes, Cke. and Farlow. Nat. size.

Fig. 86. Section of exterior of stem, showing the free, coloured ends of hyphae that form the velvety surface. $\times 400$.

Fig. 87. Ascus and paraphyses of same. $\times 400$.

Fig. 88. Free spores of same. $\times 400$.

Fig. 89. Neolecta flavo-virescens, Speg. Nat. size.

Fig. 90. Ascus containing spores of same. $\times 400$.

Fig. 91. Portion of hymenium of Coprinus atramentarius; a, cystidium, originating from the coalescence of the apical cells of two distinct hyphae; $b$, basidium, bearing four spores. $\times 400$.

Fig. 92. Portion of the hymenium of Peziza vesiculosa, Bull., showing the origin of oospores and asci. $\times 75^{\circ}$ (after Dangeard).

Fig. 93. Showing the origin of one of the protective hairs situated on the outside of the ascophore of Lachnea albo-spadicea, Phillips. Using the terms employed by Dangeard, $a$ represents the two gametes, $b$ the oospore, not yet complete, as the two nuclei have not fused. $\times 75^{\circ}$.

Fig. 94. The same in a more advanced stage; the two nuclei have fused together, and the hair, $c$, has commenced to grow from the apex of the oospore; letters as in Fig. $93 . \quad \times 750$.

Fig. 95. Hair of the same at maturity, springing from an apparently forked base; letters as in Fig. 94. $\times 400$. 
Annals of Botany
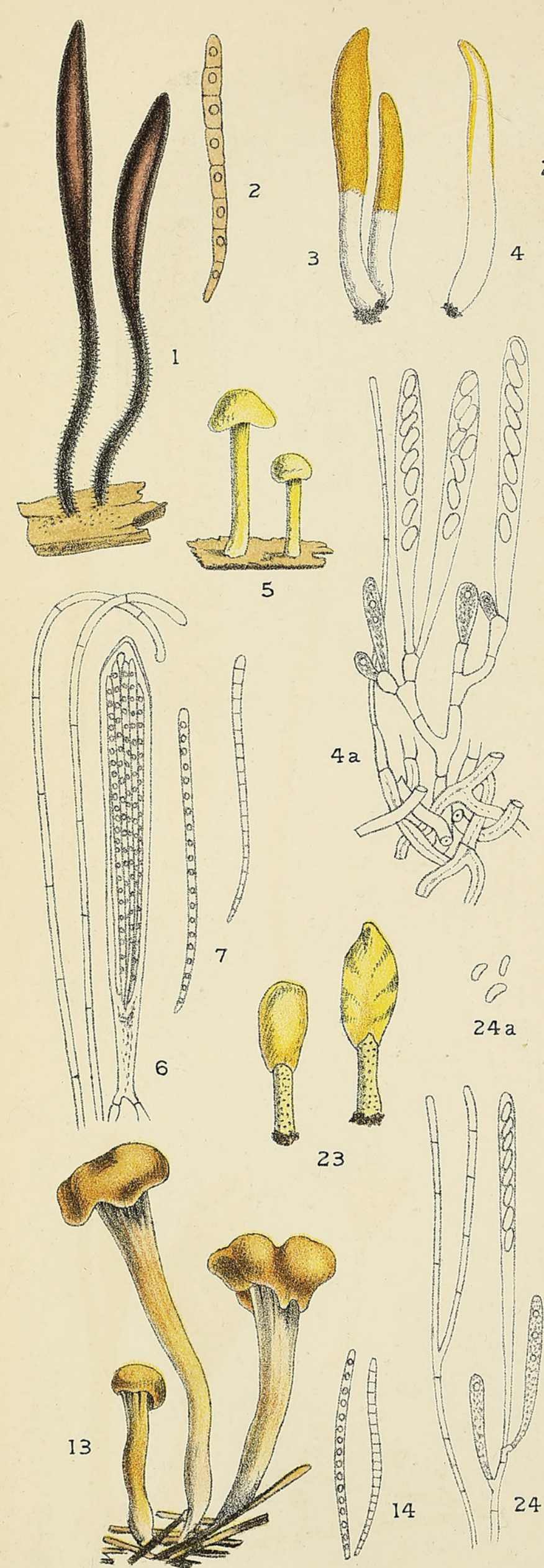

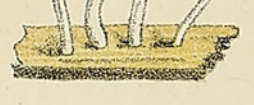

22
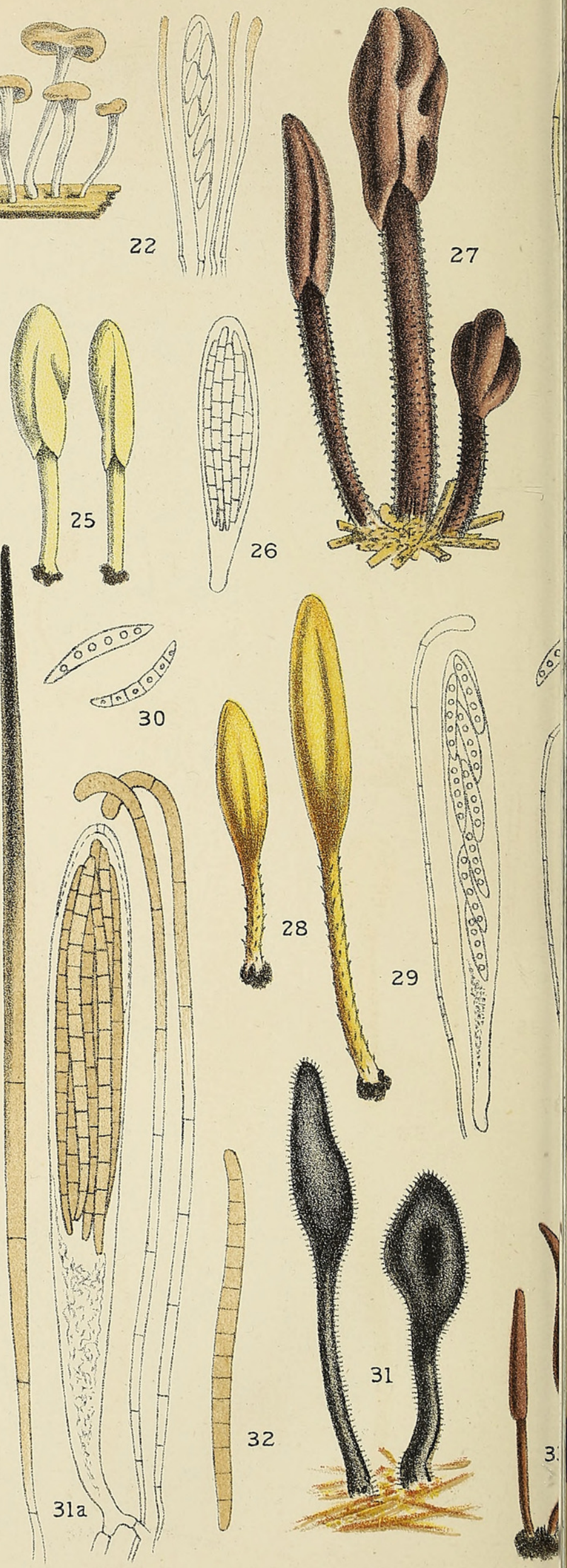

MASSEE. - GEOGLOSSEAE. 
Annals of Botany

Vol. XI, PL.XII.

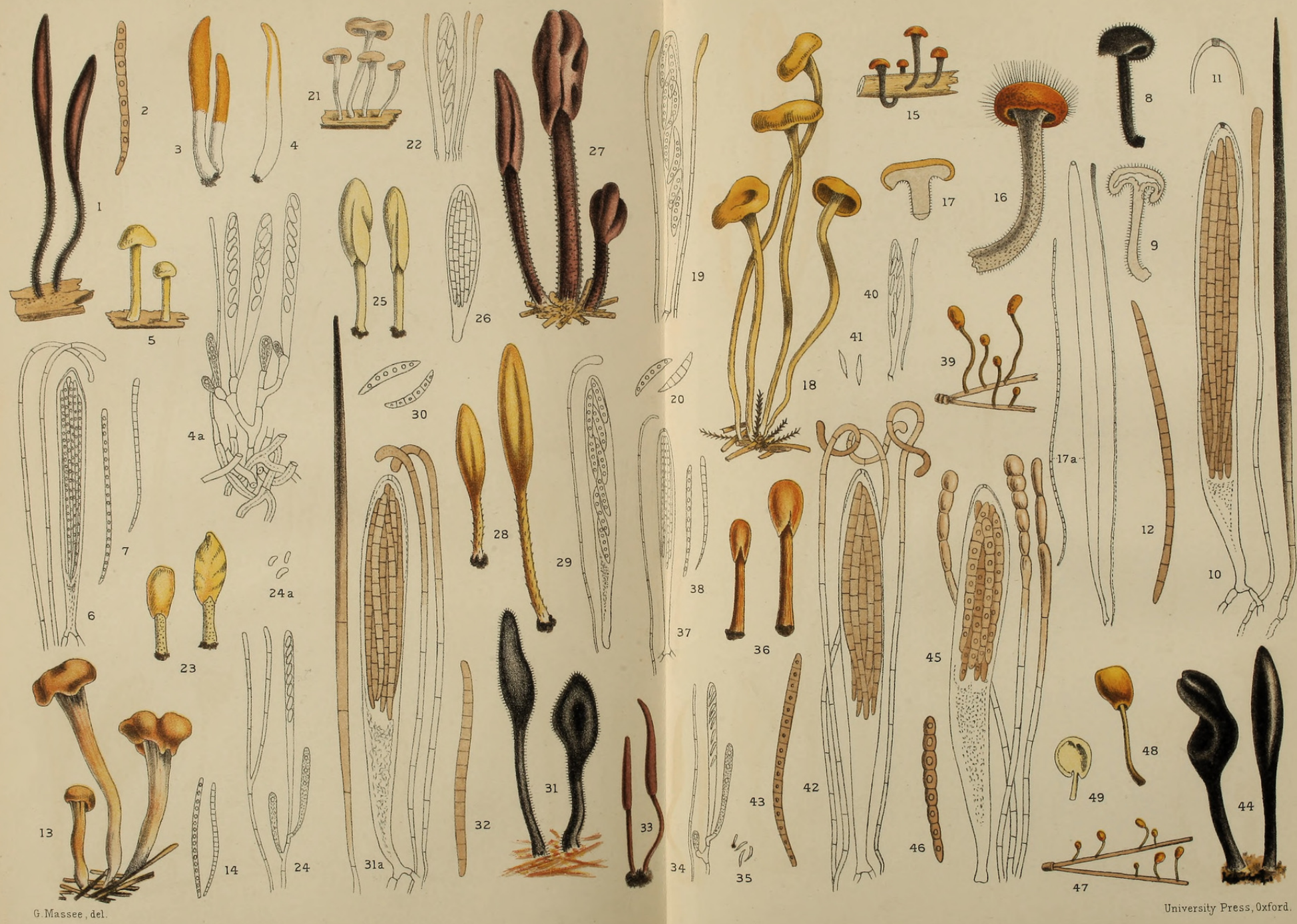



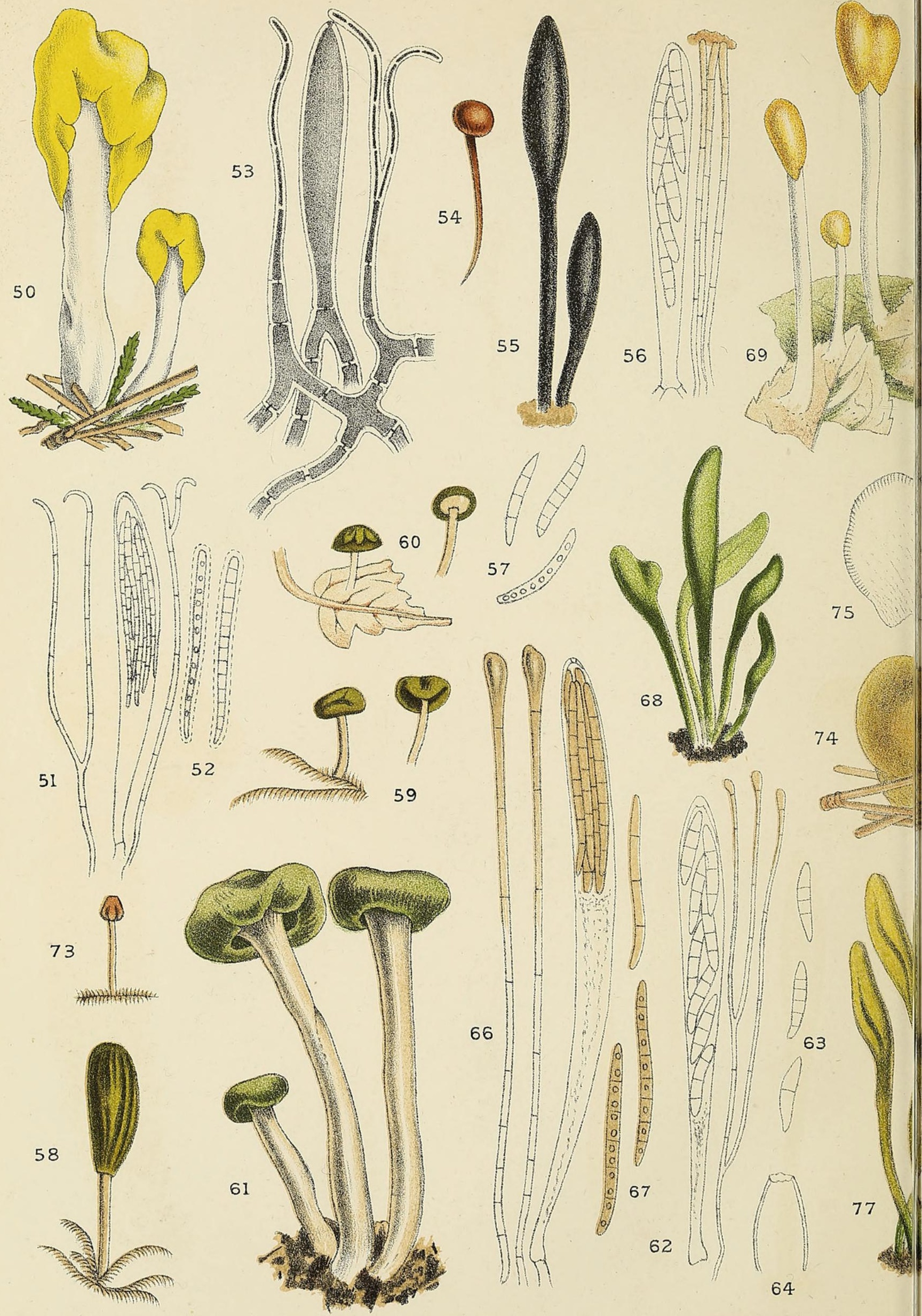

G.Massee, del

MASSEE. - GEOGLOSSEAE. 


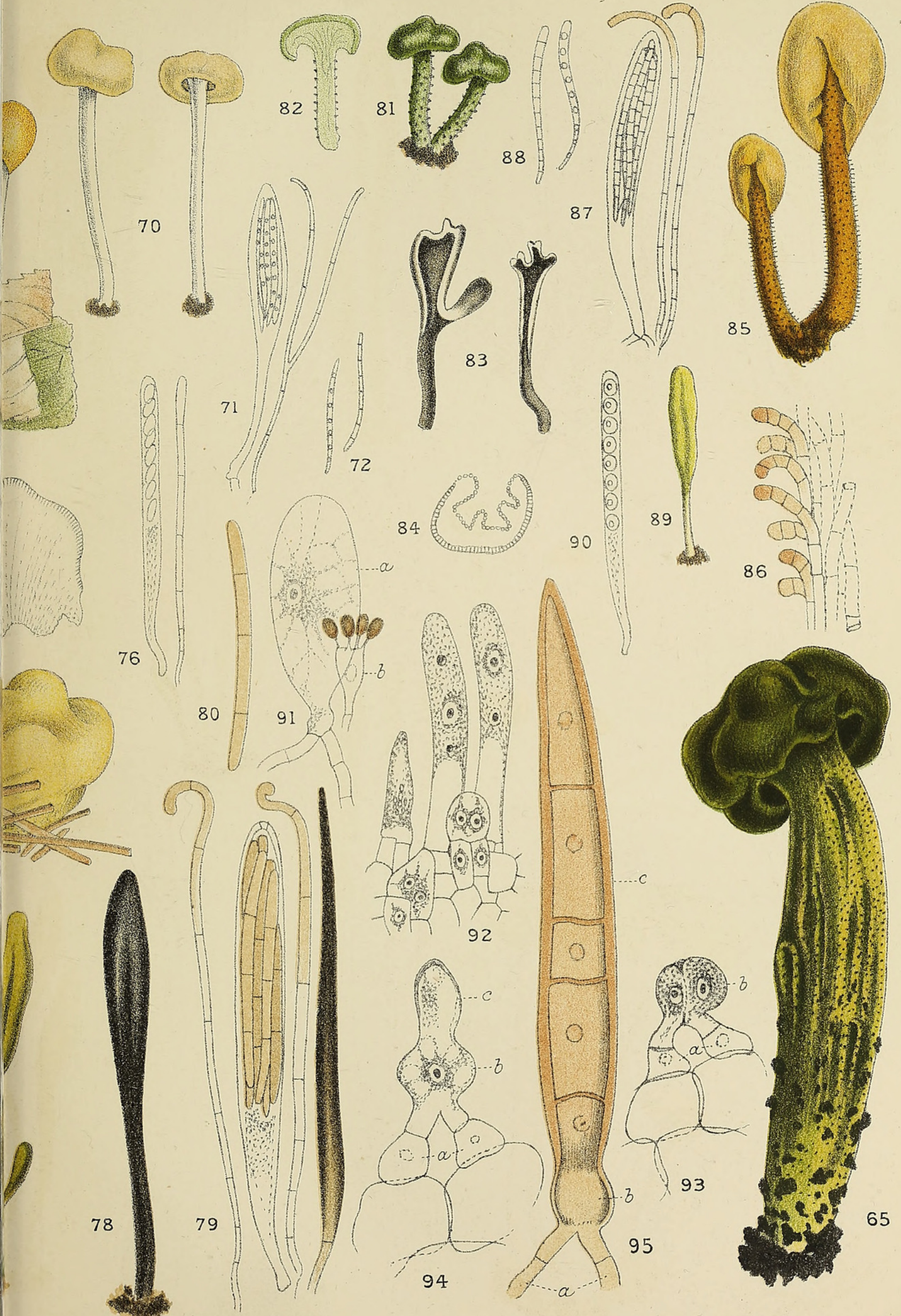

University Press, 0xford. 


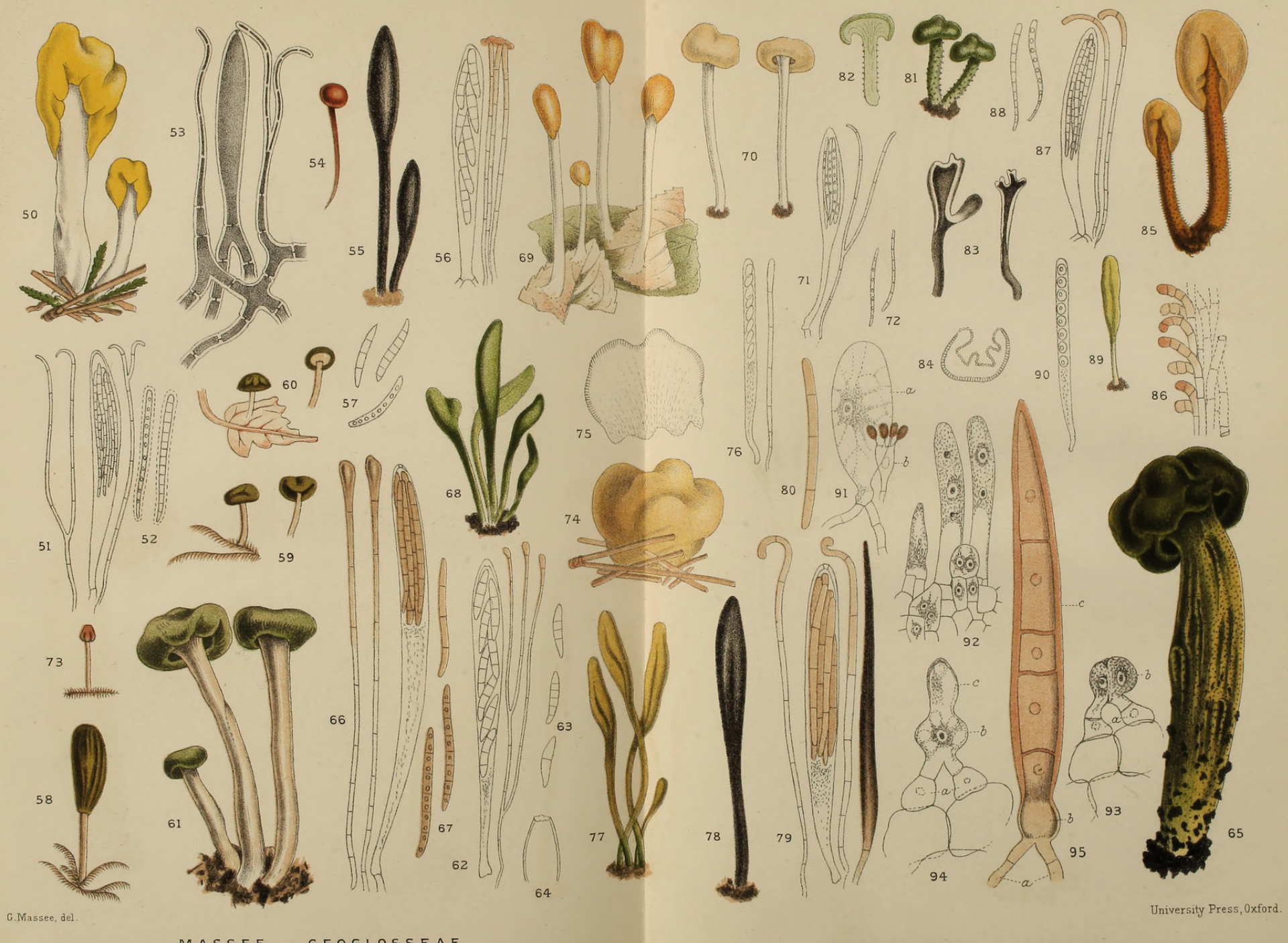



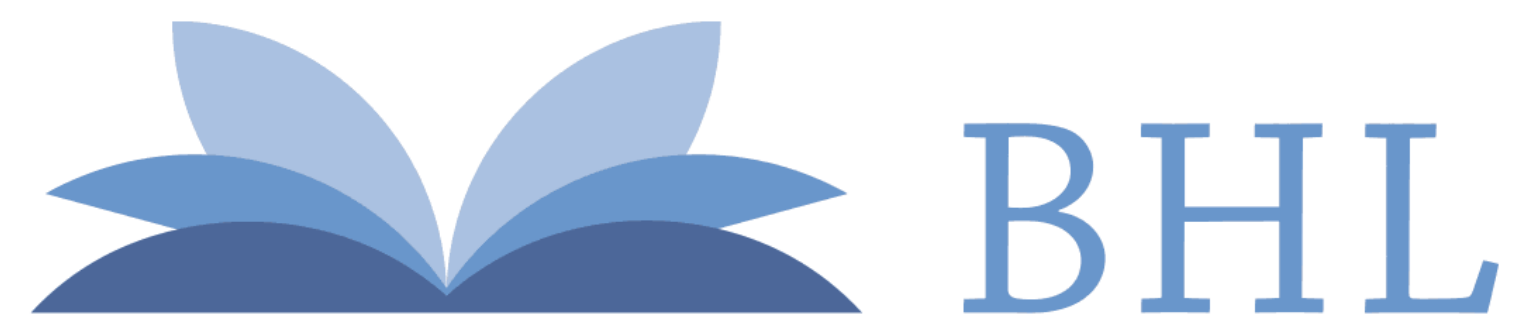

\section{Biodiversity Heritage Library}

Massee, George. 1897. "A monograph of the Geoglosseae." Annals of botany 11, 225-306. https://doi.org/10.1093/oxfordjournals.aob.a088650.

View This Item Online: https://www.biodiversitylibrary.org/item/233542

DOI: https://doi.org/10.1093/oxfordjournals.aob.a088650

Permalink: https://www.biodiversitylibrary.org/partpdf/318462

\section{Holding Institution}

Smithsonian Libraries

\section{Sponsored by}

Biodiversity Heritage Library

\section{Copyright \& Reuse}

Copyright Status: Not in copyright. The BHL knows of no copyright restrictions on this item.

This document was created from content at the Biodiversity Heritage Library, the world's largest open access digital library for biodiversity literature and archives. Visit BHL at https://www.biodiversitylibrary.org. 